\title{
Geohydrology and Numerical Simulation of the Ground-Water Flow System of Kona, Island of Hawaii
}

\section{U.S. GEOLOGICAL SURVEY}

Water-Resources Investigations Report 99-4073

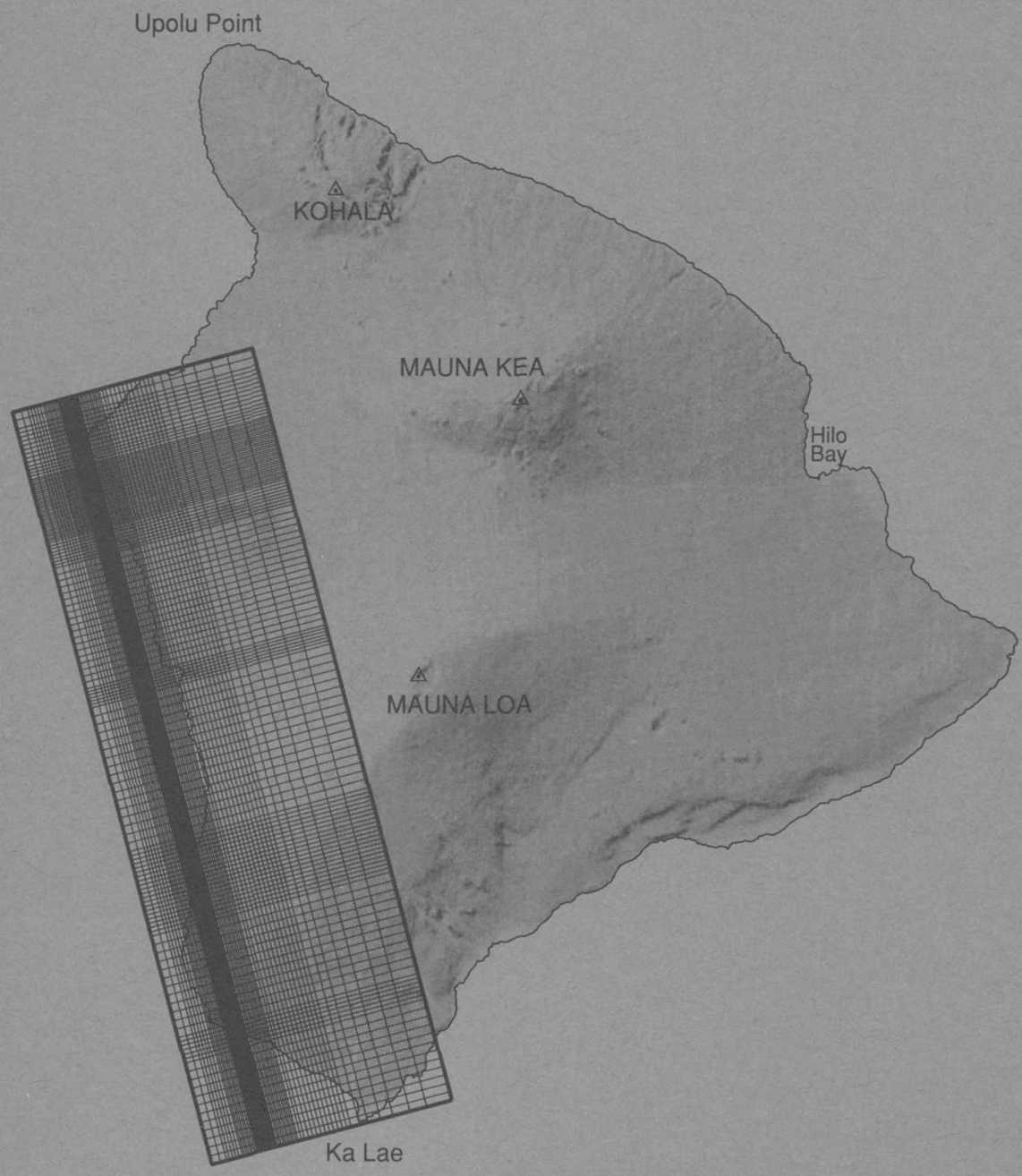

Prepared in cooperation with the STATE OF HAWAII COMMISSION ON WATER RESOURCE MANAGEMENT NATIONAL PARK SERVICE 



\title{
Geohydrology and Numerical Simulation of the Ground-Water Flow System of Kona, Island of Hawaii
}

\author{
By Delwyn S. Oki
}

U.S. GEOLOGICAL SURVEY

Water-Resources Investigations Report 99-4073

Prepared in cooperation with the STATE OF HAWAII COMMISSION ON WATER RESOURCE MANAGEMENT NATIONAL PARK SERVICE 


\section{U.S. DEPARTMENT OF THE INTERIOR BRUCE BABBITT, Secretary}

U.S. GEOLOGICAL SURVEY

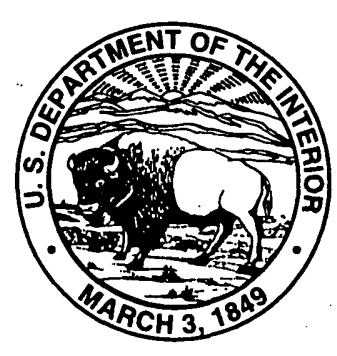

Charles G. Groat, Director

The use of firm, trade, and brand names in this report is for identification purposes only and does not constitute endorsement by the U.S. Geological Survey.

For additional information write to:

District Chief

U.S. Geological Survey

677 Ala Moana Blvd., Suite 415

Honolulu, HI 96813
Copies of this report can be purchased from:

U.S. Geological Survey

Branch of Information Services

Box 25286

Denver, CO 80225-0286 


\section{CONTENTS}

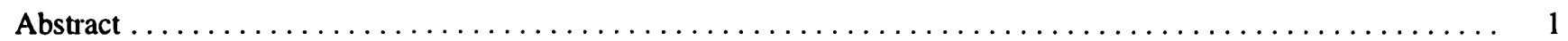

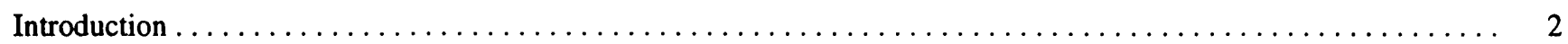

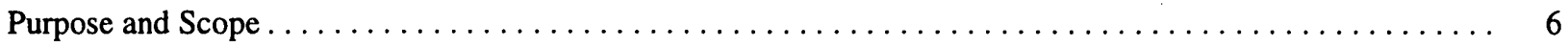

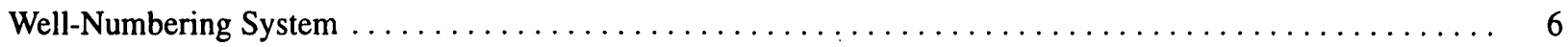

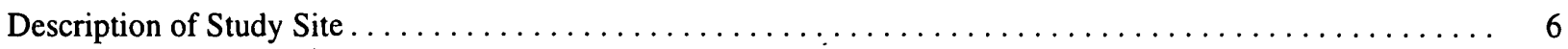

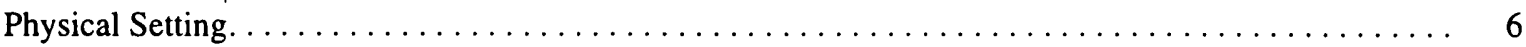

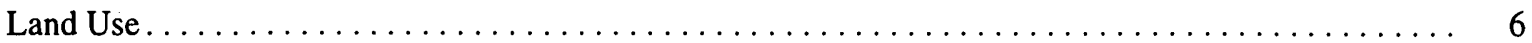

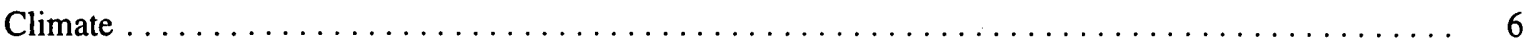

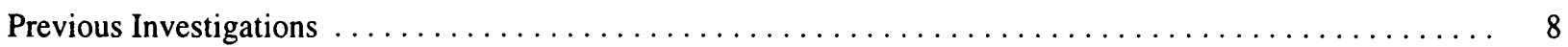

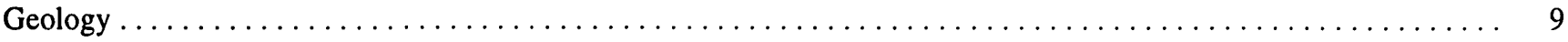

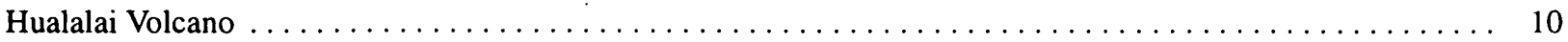

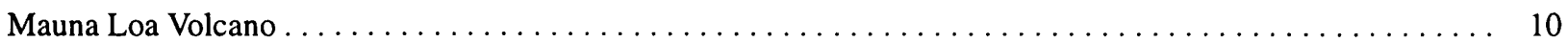

Coastal Deposits. . . . . . . . . . . . . . . . . . . . . . . . . . . . . . 12

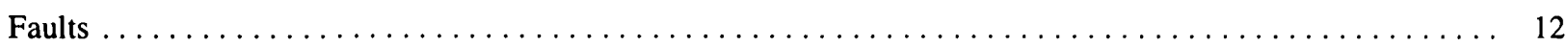

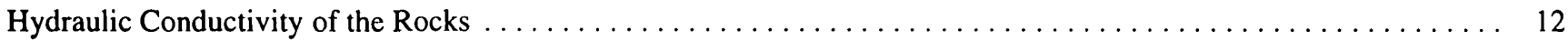

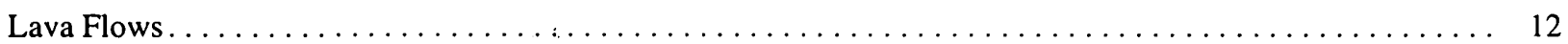

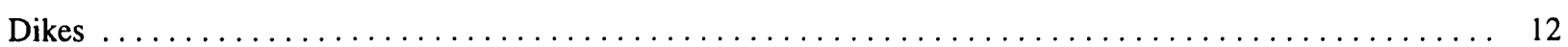

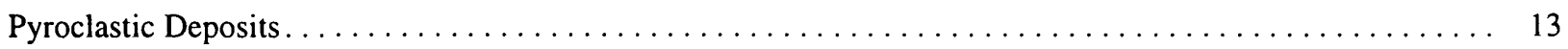

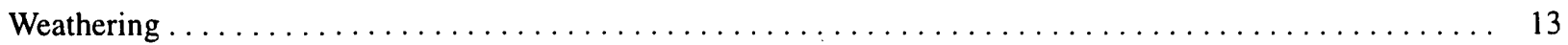

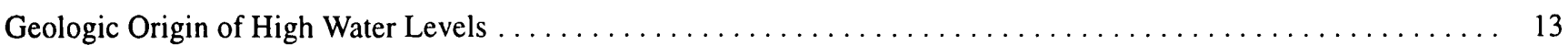

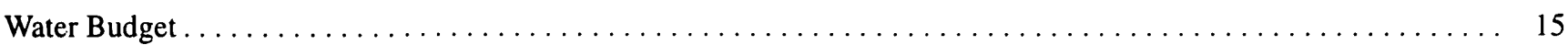

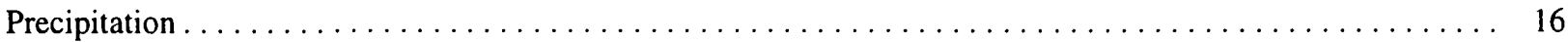

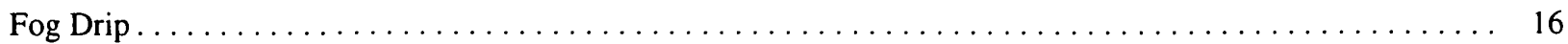

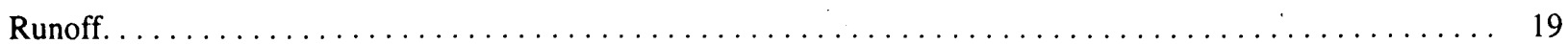

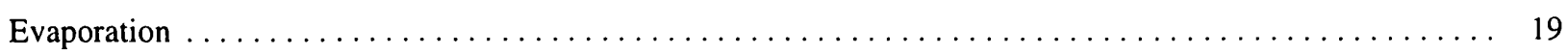

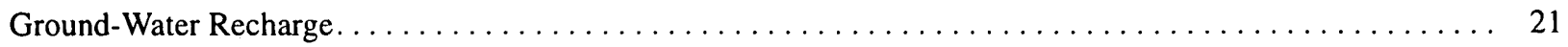

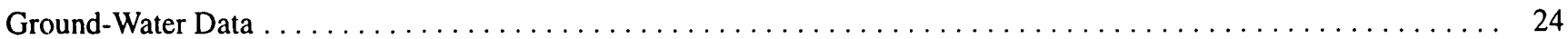

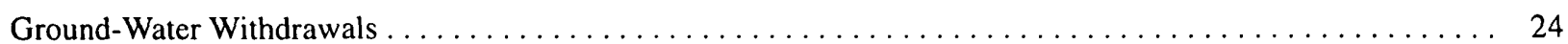

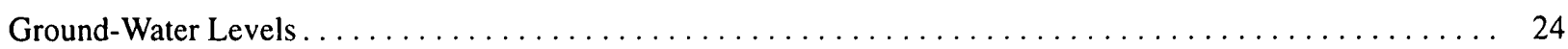

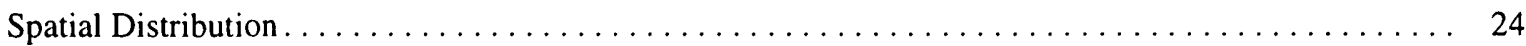

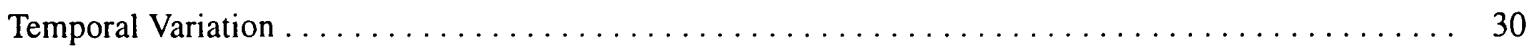

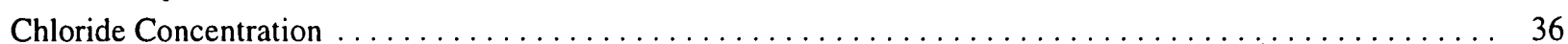

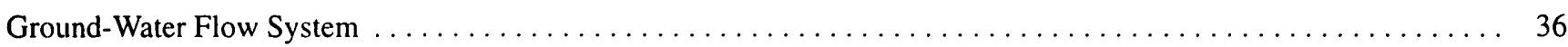

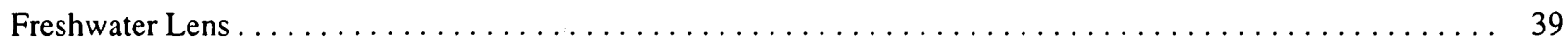

High Water-Level Area $\ldots \ldots \ldots \ldots \ldots \ldots \ldots \ldots \ldots \ldots \ldots \ldots \ldots \ldots \ldots \ldots$

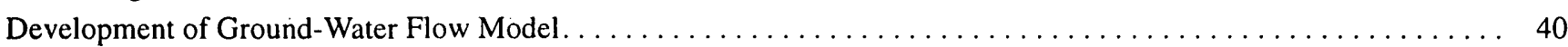

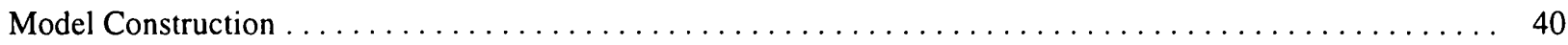

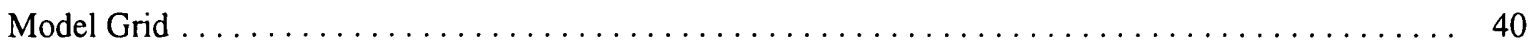

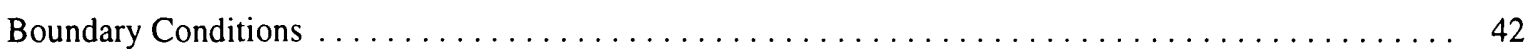

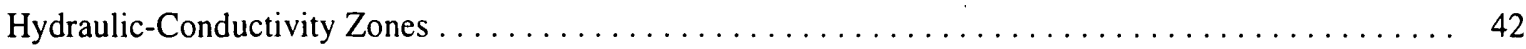

Aquifer-Storage Properties $\ldots \ldots \ldots \ldots \ldots \ldots \ldots \ldots \ldots \ldots \ldots \ldots \ldots \ldots$ 
Ground-Water Withdrawals $\ldots \ldots \ldots \ldots \ldots \ldots \ldots \ldots \ldots \ldots \ldots \ldots \ldots \ldots \ldots \ldots$

Recharge........................................44

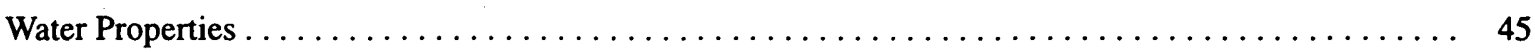

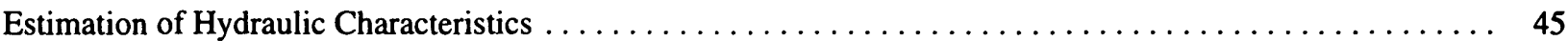

Model-Calculated Water Levels $\ldots \ldots \ldots \ldots \ldots \ldots \ldots \ldots \ldots \ldots \ldots \ldots \ldots \ldots \ldots$

Model-Calculated Ground-Water Discharge . . . . . . . . . . . . . . . . . . . . . . 49

Model Sensitivity to Recharge. . . . . . . . . . . . . . . . . . . . . . . . . . 49

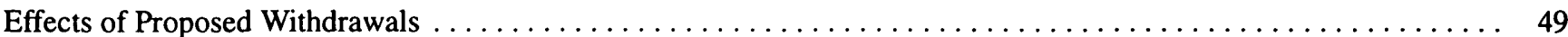

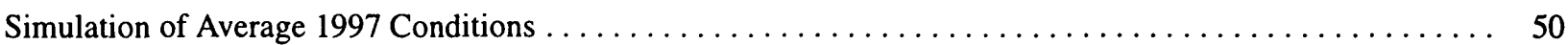

Simulation of the Hydrologic Effects of Additional Withdrawals $\ldots \ldots \ldots \ldots \ldots \ldots \ldots$

Scenario 1--25.6 Mgal/d Proposed Withdrawal between Palani Junction and Holualoa . . . . . . . . . 52

Scenario 2--9.0 Mgal/d Proposed Withdrawal between Palani Junction and Holualoa. . . . . . . . . . 55

Scenario 3--5.0 Mgal/d Proposed Withdrawal between Palani Junction and Holualoa. . . . . . . . . . 55

Model Limitations . . . . . . . . . . . . . . . . . . . . . . . . . . . . . . . . . . 57

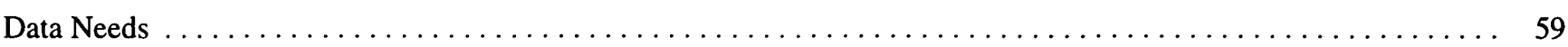

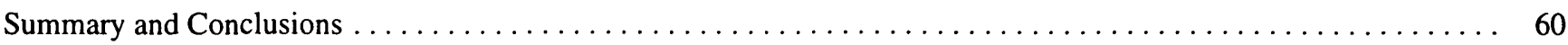

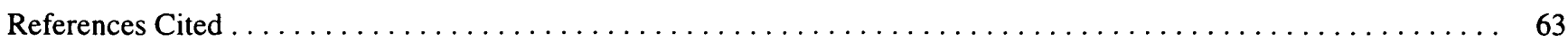

Appendix A. Model Response to Changes in Hydraulic Characteristics . . . . . . . . . . . . . . . . 66

Model Response to Horizontal Hydraulic Conductivity of the Dike-Complex Zone . . . . . . . . . . 66

Model Response to Horizontal Hydraulic Conductivity of the Dike-Free Zone. . . . . . . . . . . . . 70

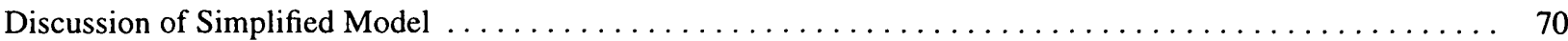

\section{FIGURES}

1-5. Maps showing:

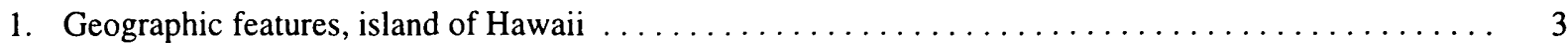

2. Kona study area and district boundaries, island of Hawaii $\ldots \ldots \ldots \ldots \ldots \ldots$

3. Selected wells in the Kona area, island of Hawaii $\ldots \ldots \ldots \ldots \ldots \ldots \ldots \ldots \ldots \ldots \ldots \ldots \ldots \ldots \ldots \ldots \ldots$

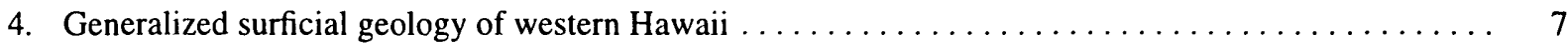

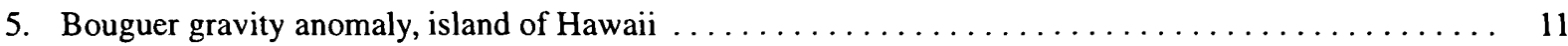

6. Schematic cross sections showing geologic structures that may be impounding ground water to high levels (greater than 40 feet above sea level) in the Kona area, island of Hawaii: (A) buried dike complex; $(\mathrm{B})$ buried fault system; $(\mathrm{C})$ buried, massive lava flows $\ldots \ldots \ldots \ldots \ldots \ldots \ldots$

7. Graph showing drawdown as a function of time at well 3155-01 during an aquifer test starting

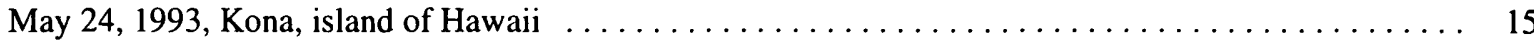

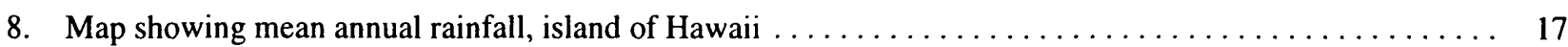

9. Graphs showing annual and mean monthly rainfall at stations $68,73.2$, and 73 , Kona, island of Hawaii ... 18

10-12. Maps showing:

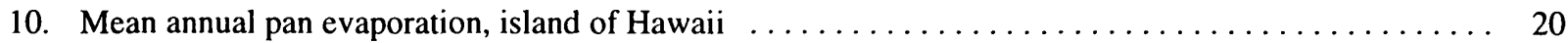

11. Aquifer-system boundaries (Mink and Lau, 1993) and previously estimated ground-water

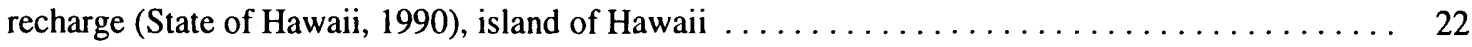

12. Average annual ground-water recharge within the Kona study area, island of Hawaii. . . . . . . 23

13-14. Graphs showing:

13. Monthly pumpage from selected wells located seaward of the high water-level area, Kona,

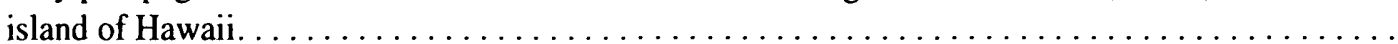


14. Monthly pumpage from selected Hawaii County wells, high water-level area, Kona, island of

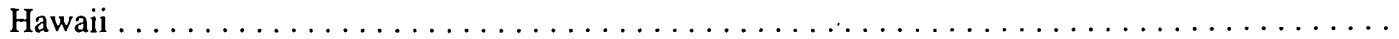

15. Map showing time-averaged measured water levels for 1991-93 in the Kona area, island of Hawaii

16-20. Graphs showing:

16. Water levels estimated from air-line pressure measurements in selected wells located seaward of the high water-level area, Kona, island of Hawaii $\ldots \ldots \ldots \ldots \ldots \ldots \ldots \ldots \ldots$

17. Measured water levels in selected wells located seaward of the high water-level area,

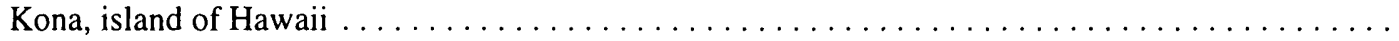

18. Measured water levels in selected wells, high water-level area, Kona, island of Hawaii . . . . . . 34

19. Salinity profiles, measured on June 15 and 21,1991 , in selected monitoring wells, northern

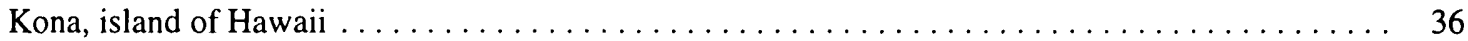

20. Chloride concentration of water samples from selected wells, Kona, island of Hawaii . . . . . . . 38

21-23. Maps showing:

21. Finite-difference model grid and hydraulic-conductivity zones for the Kona area, island of Hawaii ....

22. Finite-difference model grid and head-dependent discharge cells for the Kona area, island of Hawaii ...

23. Average annual recharge used in the ground-water flow model for the Kona area, island of

Hawaii

24. Graph showing measured and model-calculated water levels for 1991-93 pumping conditions, Kona, island of Hawaii, for a coastal leakance of 0.05 feet per day per foot, a horizontal hydraulic conductivity of 7,500 feet per day for the dike-free, volcanic-rocks zone, a horizontal hydraulic conductivity of 0.1 feet per day for the dike-complex zone, a horizontal hydraulic conductivity of 0.5 feet per day for the southern marginal dike zone, and a horizontal hydraulic conductivity of 10 feet per day for

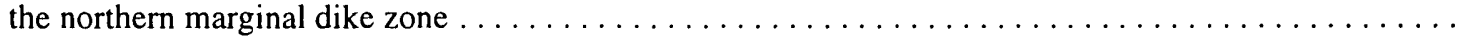

25-29. Maps showing:

25. Model-calculated and measured 1991-93 water levels for the Kona area, island of Hawaii .........

26. Model-calculated 1997 water levels for the Kona area, island of Hawaii . . . . . . . . . . . . . . . . . . .

27. Model-calculated water-level drawdown and coastal-discharge reduction, relative to 1997 model-calculated conditions, caused by attempting to withdraw $25.6 \mathrm{Mgal} / \mathrm{d}$ from the high water-level area, Kona, island of Hawaii

28. Model-calculated water-level drawdown and coastal-discharge reduction, relative to 1997 model-calculated conditions, caused by attempting to withdraw $9.0 \mathrm{Mgal} / \mathrm{d}$ from the high

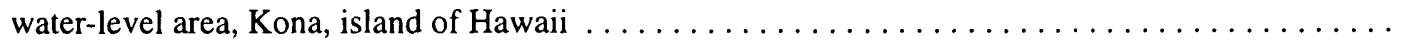

29. Model-calculated water-level drawdown and coastal-discharge reduction, relative to 1997 model-calculated conditions, caused by withdrawing $5.0 \mathrm{Mgal} / \mathrm{d}$ from the high water-level area between Palani Junction and Holualoa, Kona, island of Hawaii

\section{APPENDIX FIGURES}

A1-3. Graphs showing:

A1. Measured and model-calculated water levels for 1991-93 pumping conditions, Kona, island of Hawaii, for various values of coastal leakance, a horizontal hydraulic conductivity of 7,500 feet per day for the combined dike-free, volcanic-rocks zone, and a horizontal hydraulic conductivity of 0.1 feet per day for the combined dike-complex zone

A2. Measured and model-calculated water levels for 1991-93 pumping conditions, Kona, island of Hawaii, for various values of coastal leakance, a horizontal hydraulic conductivity of 7,500 feet per day for the combined dike-free, volcanic-rocks zone, and a horizontal hydraulic conductivity of 0.5 feet per day for the combined dike-complex zone $\ldots \ldots \ldots \ldots \ldots \ldots$ 
A3. Measured and model-calculated water levels for 1991-93 pumping conditions, Kona, island of Hawaii, for various values of coastal leakance, a horizontal hydraulic conductivity of 2,500 feet per day for the combined dike-free, volcanic-rocks zone, and a horizontal hydraulic conductivity of 0.1 feet per day for the combined dike-complex zone $\ldots \ldots \ldots \ldots \ldots \ldots \ldots$

\section{TABLES}

1. U.S. Geological Survey continuous-record surface-water stations, Kona, island of Hawaii . . . . . . . . . . . . 19

2. Initial available water level from selected wells in the Kona area, island of Hawaii . . . . . . . . . . . . . . . . 29

3. Initial available chloride concentration of water from selected wells in the Kona area, island of Hawaii. . . . . . 37

4. Description of pumped wells and reported pumping rates, Kona area, island of Hawaii. . . . . . . . . . . 44

5. Final parameter values used in the Kona ground-water flow model, island of Hawaii $\ldots \ldots \ldots \ldots \ldots \ldots \ldots$

6. Recharge used in the model and distribution of model-calculated ground-water discharge, Kona, island of Hawaii . . . . . . . . . . . . . . . . . . . . . . . . . . . . . . . . . . . . . . 49

7. Pumping rates used in model scenarios 1 through 3, Kona area, island of Hawaii $\ldots \ldots \ldots \ldots \ldots \ldots \ldots .52$

8. Model cells in which the water table is lowered below the bottom of simulated wells, and modelcalculated rate of saltwater pumpage from cells in which the interface rises above the bottom of simulated wells, Kona, island of Hawaii $\ldots \ldots \ldots \ldots \ldots \ldots \ldots \ldots \ldots \ldots \ldots \ldots \ldots \ldots \ldots \ldots \ldots \ldots \ldots \ldots$

\section{Conversion Factors}

\begin{tabular}{rll}
\hline Multiply & By & To obtain \\
mile $(\mathrm{mi})$ & 1.609 & kilometer \\
inch $(\mathrm{in})$. & 25.4 & millimeter \\
inch per year $(\mathrm{in} / \mathrm{yr})$ & 2.54 & centimeter per year \\
foot $(\mathrm{ft})$ & 0.3048 & meter \\
foot per day $(\mathrm{ft} / \mathrm{d})$ & 0.3048 & meter per day \\
foot per day per foot $(\mathrm{ft} / \mathrm{d} / \mathrm{ft})$ & 1 & meter per day per meter \\
square foot per pound $\left(\mathrm{ft}^{2} / \mathrm{lb}\right)$ & 0.020885 & square meter per newton \\
foot per mile $(\mathrm{ft} / \mathrm{mi})$ & 0.1894 & meter per kilometer \\
pound per cubic foot $\left(\mathrm{lb} / \mathrm{ft}^{3}\right)$ & 16.02 & kilogram per cubic meter \\
pound second per square foot $\left(\mathrm{lb} \bullet \mathrm{s} / \mathrm{ft}^{2}\right)$ & 47.88 & pascal per second \\
gallon per minute $(\mathrm{gal} / \mathrm{min})$ & 0.003785 & cubic meter per minute \\
million gallons per day $(\mathrm{Mgal} / \mathrm{d})$ & 0.04381 & cubic meter per second
\end{tabular}

Water temperature is given in degree Celsius $\left({ }^{\circ} \mathrm{C}\right)$, which can be converted to degrees Fahrenheit $\left({ }^{\circ} \mathrm{F}\right)$ by the following equation:

$$
{ }^{\circ} \mathrm{F}=1.8 \times{ }^{\circ} \mathrm{C}+32 \text {. }
$$

Abbreviations used in water-quality descriptions: $\mathrm{mg} / \mathrm{L}$, milligrams per liter 


\section{Geohydrology and Numerical Simulation of the Ground- Water Flow System of Kona, Island of Hawaii}

\section{By Delwyn S. Oki}

\section{Abstract}

Prior to the early 1990's, ground-water in the Kona area, which is in the western part of the island of Hawaii, was withdrawn from wells located within about $3 \mathrm{mi}$ from the coast where water levels were less than 10 feet above sea level. In 1990, exploratory drilling in the uplands east of the existing coastal wells first revealed the presence of high water levels (greater than 40 feet above sea level) in the Kona area. Measured water levels from 16 wells indicate that high water levels exist in a zone parallel to and inland of the Kona coast, between Kalaoa and Honaunau. Available hydrologic and geophysical evidence is generally consistent with the concept that the high ground-water levels are associated with a buried dike complex.

A two-dimensional (areal), steady-state, freshwater-saltwater, sharp-interface ground-water flow model was developed for the Kona area of the island of Hawaii, to enhance the understanding of (1) the distribution of aquifer hydraulic properties, (2) the conceptual framework of the ground-water flow system, and (3) the regional effects of groundwater withdrawals on water levels and coastal discharge. The model uses the finite-difference code SHARP.

To estimate the hydraulic characteristics, average recharge, withdrawals, and water-level conditions for the period 1991-93 were simulated. The following horizontal hydraulic-conductivity values were estimated: (1) 7,500 feet per day for the dikefree volcanic rocks of Hualalai and Mauna Loa, (2) 0.1 feet per day for the buried dike complex of Hualalai, (3) 10 feet per day for the northern marginal dike zone (north of Kalaoa), and (4) 0.5 feet per day for the southern marginal dike zone between Palani Junction and Holualoa. The coastal leakance was estimated to be 0.05 feet per day per foot.

Measured water levels indicate that ground water generally flows from inland areas to the coast. Model results are in general agreement with the limited set of measured water levels in the Kona area. Model results indicate, however, that water levels do not strictly increase in an inland direction and that a ground-water divide exists within the buried dike complex. Data are not available, however, to verify model results in the area near and inland of the model-calculated ground-water divide.

Three simulations to determine the effects of proposed withdrawals from the high water-level area on coastal discharge and water levels, relative to model-calculated, steady-state coastal discharge and water levels for 1997 withdrawal rates, show that the effects are widespread. During 1997, the total withdrawal of ground water from the high water-level area between Palani Junction and Holualoa was about 1 million gallons per day. Model results indicate that it may not be possible to withdraw 25.6 million gallons per day of freshwater from this area between Palani Junction and Holualoa, but that it may be possible to withdraw between 5 to 8 million gallons per day from the same area. For a proposed withdrawal rate of 5.0 million gallons per day uniformly distributed to 12 sites between Palani Junction and Holualoa, the model-calculated drawdown of 0.01 foot or more extends about 9 miles north-northwest and about 7 miles south of the proposed well sites. In all scenarios, freshwater coastal discharge is reduced by an 
amount equal to the additional freshwater withdrawal.

Additional data needed to improve the understanding of the ground-water flow system in the Kona area include: (1) a wider spatial distribution and longer temporal distribution of water levels, (2) improved information about the subsurface geology, (3) independent estimates of hydraulic conductivity, (4) improved recharge estimates, and (5) information about the vertical distribution of salinity in ground water.

\section{INTRODUCTION}

The Kona area of the island of Hawaii (fig. 1) is a popular destination for visitors to the island. The Kona area in this report includes the South Kona District and parts of the North Kona and Kau Districts (fig. 2), and is bounded on the north by the northwest rift zone of Hualalai Volcano, on the east by the south-southeast rift zone of Hualalai Volcano and the southwest rift zone of Mauna Loa Volcano, and on the west and south by the coast. The demand for potable water in the Kona area has increased in response to increases in the resident population and the number of visitors to the area. For instance, from 1970 to 1990 , the combined resident population in the North and South Kona Districts of western Hawaii increased from 8,836 to 29,942 (State of Hawaii, 1994). Although rain catchments have and continue to provide water for some households, ground water is currently the main source of domestic water in the Kona area. Reported ground-water withdrawals from wells in the Kona area increased from about 0.5 $\mathrm{Mgal} / \mathrm{d}$ in 1966 (Davis and Yamanaga, 1968) to 14.0 $\mathrm{Mgal} / \mathrm{d}$ in 1997 (computed from unpub. data from Hawaii Commission on Water Resource Management).

Prior to the early 1990's, ground water was withdrawn from wells in an area adjacent to the coast that is characterized by relatively low water levels (generally less than $10 \mathrm{ft}$ above sea level), small-magnitude horizontal head gradients (on the order of a foot per mile), and high-permeability dike-free volcanic rocks. The ground water withdrawn from these wells is from a body of freshwater or brackish water floating on denser, underlying saltwater. In 1990, exploratory drilling in the uplands east of the existing coastal wells first revealed the presence of high water levels in the area between Kalaoa and Honaunau (fig. 2). For the purposes of this report, high water levels are defined as water levels greater than $40 \mathrm{ft}$ above sea level. In the Kona area, a high water level was first discovered at Keauhou well 3355-01 (fig. 3), drilled about $2.1 \mathrm{mi}$ from the coast to a depth of $33 \mathrm{ft}$ above sea level (well $3355-01$ is open or screened between altitudes of $33 \mathrm{ft}$ and $258 \mathrm{ft}$ ). On August 2, 1990, the water level measured in well 3355-01 was $278 \mathrm{ft}$ above sea level, considerably higher than the water levels measured in wells closer to the coast. A high water level was also discovered to the north of well 3355-01 about a month later at the State Kalaoa Exploratory Well 4358-01 (fig. 3), drilled about $4.3 \mathrm{mi}$ from the coast to a depth of $51 \mathrm{ft}$ below sea level (well 4358-01 is open or screened between altitudes of $-51 \mathrm{ft}$ and $69 \mathrm{ft}$ ). On September 18 , 1990 , the water level measured in well 4358-01 was 255 ft above sea level. Since 1990, a total of 16 wells (including well 3857-01 which was abandoned) with measured water levels higher than $40 \mathrm{ft}$ above sea level have been drilled in the area between Kalaoa and Honaunau at land surface altitudes of about $1,600 \mathrm{ft}$.

In 1997, $2.1 \mathrm{Mgal} / \mathrm{d}$ of fresh ground water was withdrawn from four Hawaii County wells in which high water levels were measured (computed from unpub. data from Hawaii Commission on Water Resource Management). Because the demand for ground water from the high water-level area is likely to increase, there is a need to better understand the hydrologic effects of additional withdrawals if the groundwater system in the Kona area is to be effectively managed.

In cooperation with the State of Hawaii Commission on Water Resource Management (CWRM), the U.S. Geological Survey (USGS) undertook an investigation of the ground-water flow system of the Kona area. A numerical ground-water flow model of the Kona area was developed to enhance the understanding of (1) the conceptual framework of the ground-water flow system, (2) the distribution of aquifer hydraulic properties, and (3) the regional effects of ground-water withdrawals on water levels and coastal discharge. During the course of this investigation, data needs for improving the understanding of the ground-water flow system were identified. 


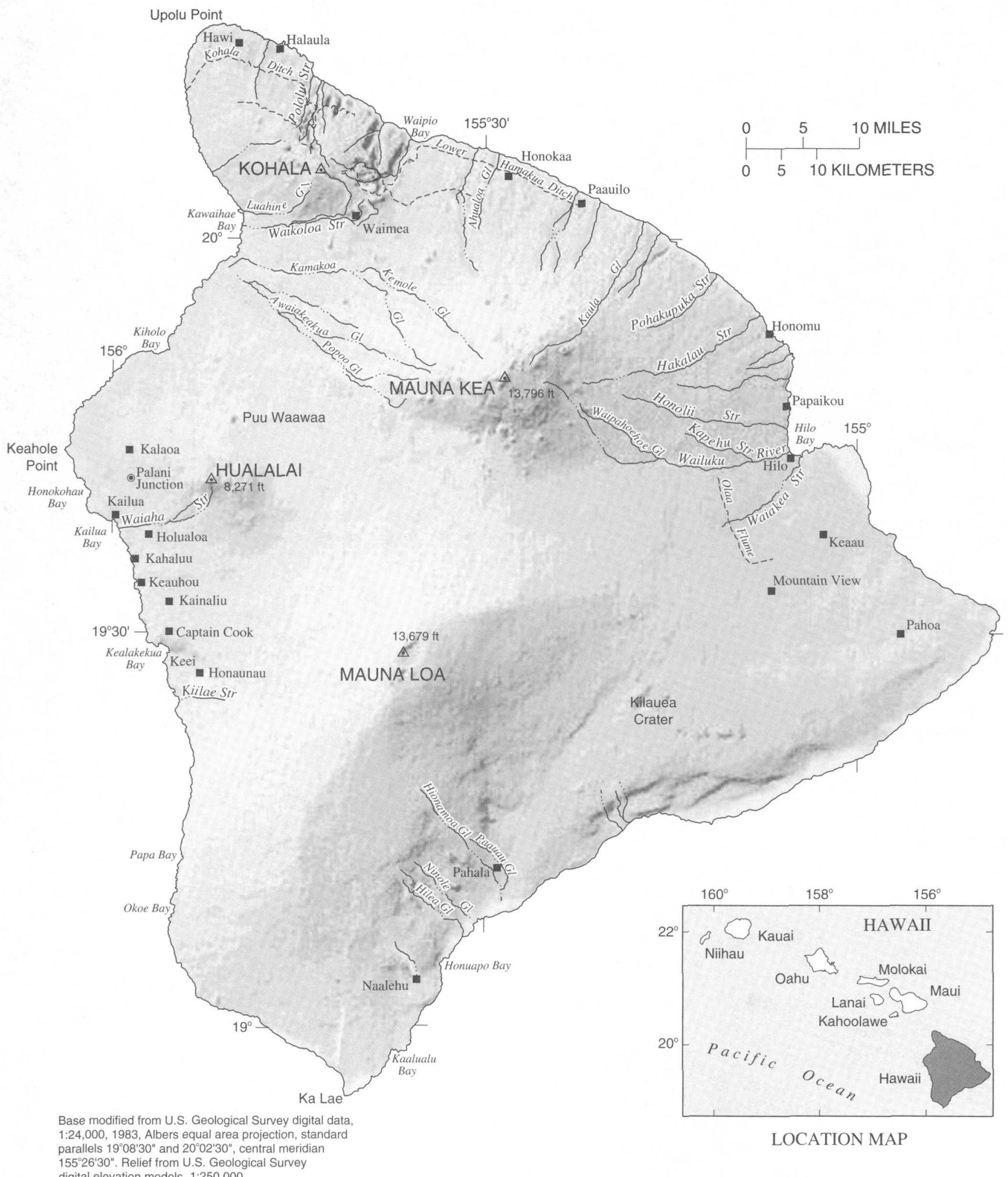

$155^{\circ} 26^{\prime} 30^{\prime \prime}$. Relief from U.S. Geological Survey

digital elevation models, 1:250,000

Figure 1. Geographic features, island of Hawaii. 


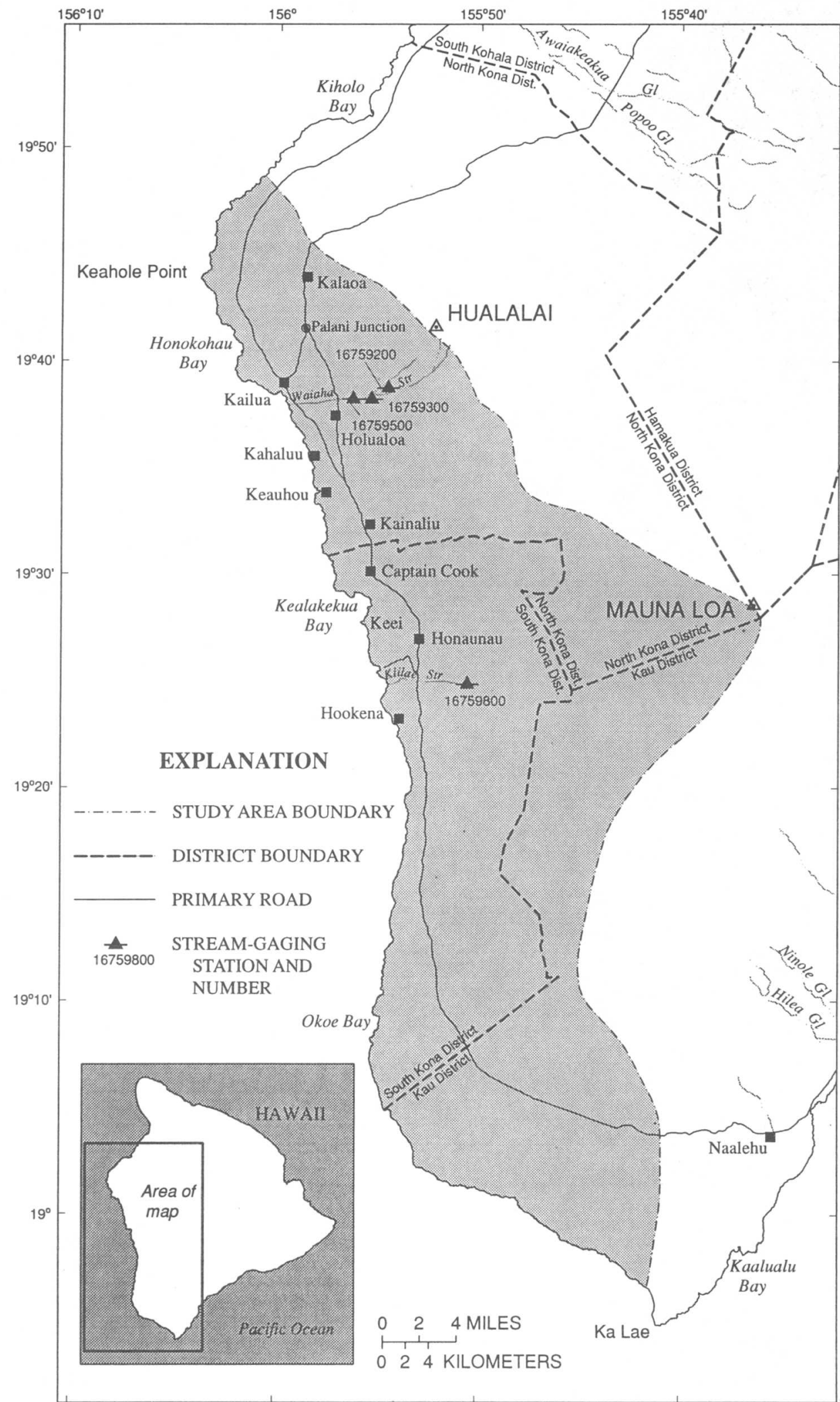

Base modified from U.S. Geological Survey digital data, $1: 24,000,1983$, Albers equal area projection, standard parallels $19^{\circ} 08^{\prime} 30^{\prime \prime}$ and $20^{\circ} 02^{\prime} 30^{\prime \prime}$, central meridian $155^{\circ} 26^{\prime} 30^{\prime \prime}$

Figure 2. Kona study area and district boundaries, island of Hawaii. 


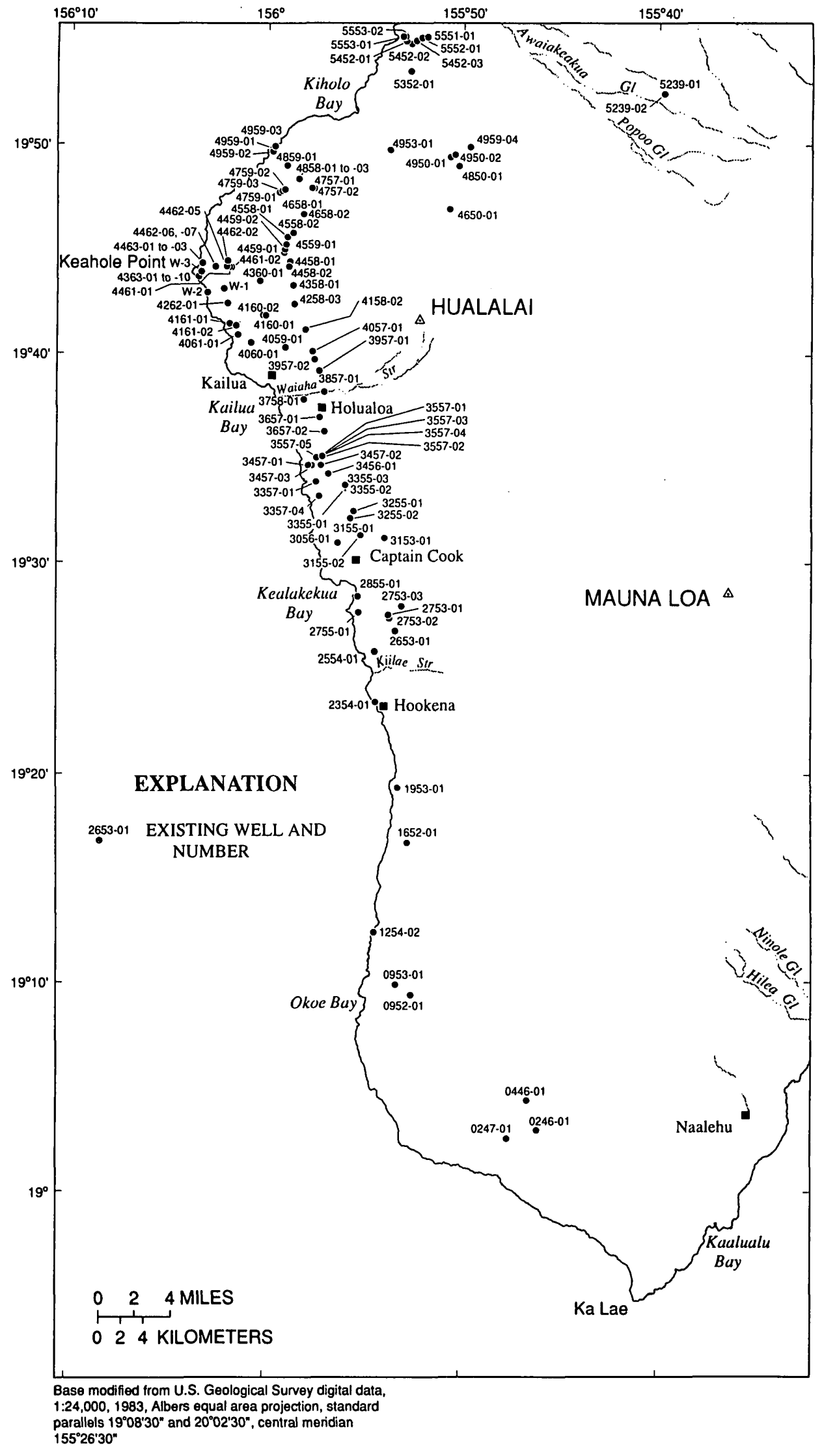

Figure 3. Selected wells in the Kona area, island of Hawaii. 


\section{Purpose and Scope}

The purpose of this report is to describe (1) the geologic and hydrologic setting of the Kona area, (2) the numerical ground-water flow model developed, (3) the results of model simulations that qualitatively assess the hydrologic effects of withdrawals at rates in excess of the average 1997 rates, and (4) data needs.

No new data were collected as part of this study; only existing water-level and ground-water withdrawal information were used to develop the conceptual framework of the ground-water flow system. A numerical ground-water flow model of the Kona area was used to refine the conceptual framework and to estimate the effects of different withdrawal scenarios on regional ground-water levels and ground-water discharge. The numerical model used data from the period 1991 through 1993 to estimate hydraulic properties of the volcanic rocks. Average ground-water withdrawals for 1997 and estimated long-term average natural recharge were used in the model to simulate ground-water levels and discharge, which in turn were used as the base to compute simulated water-level drawdown and change in freshwater coastal discharge for three withdrawal scenarios.

\section{Well-Numbering System}

Wells mentioned in this report are numbered according to the State of Hawaii numbering system. Well numbers contain seven digits and are based on a latitude-longitude one-minute grid system. Well numbers are of the form:

$$
\text { a-bbcc-dd, }
$$

where:

$a$ is the island code;

$\mathrm{bb}$ is the minutes of latitude of the southeastern corner of the one-minute grid;

$\mathrm{cc}$ is the minutes of longitude of the southeastern corner of the one-minute grid, and

dd is the sequential well number within the oneminute grid.

An island code of "8" is used for all wells on the island of Hawaii and is omitted in this report. For wells to the west of longitude $156^{\circ} \mathrm{W}$, the value for $\mathrm{cc}$ is the minutes of longitude of the southeastern corner of the one-minute grid plus 60 .

\section{Description of Study Site}

\section{Physical Setting}

The island of Hawaii, which has an area of about $4,030 \mathrm{mi}^{2}$, is the largest of the Hawaiian islands and lies between longitude $154^{\circ} 48^{\prime} \mathrm{W}$ and $156^{\circ} 04^{\prime} \mathrm{W}$ and between latitude $18^{\circ} 54^{\prime} \mathrm{N}$ and $20^{\circ} 17^{\prime} \mathrm{N}$ (fig. 1). The island is composed of five shield volcanoes: Kohala, Mauna Kea, Hualalai, Mauna Loa, and Kilauea (Langenheim and Clague, 1987). The Kona study area includes the southern and northwestern parts of Hualalai and the western part of Mauna Loa. Hualalai, which last erupted in 1801 , rises to an altitude of $8,271 \mathrm{ft}$. Mauna Loa last erupted in 1984 and rises to an altitude of 13,679 ft. The slopes of Hualalai and Mauna Loa generally are smooth, except where shallow stream courses have formed or where cinder cones exist. A seaward-facing escarpment at Kealakekua Bay is the expression of the Kealakekua fault system which extends inland for about $3 \mathrm{mi}$ (fig. 4) (Macdonald and others, 1983).

\section{Land Use}

Land use in the State is classified by the Hawaii State Land Use Commission into conservation, urban, rural, and agricultural zones. In the Kona area, conservation and agricultural zones cover more than 90 percent of the land. The conservation lands generally represent forest reserve and other unused areas. Agricultural lands are used primarily for livestock grazing or for orchards. Coffee and macadamia nuts are among the commercial crops grown in the Kona area.

Natural vegetation on the slopes of Mauna Loa and Hualalai (Jacobi, 1989) reflect altitudinal changes in climate. In the wet areas, between about 2,000 and $6,000 \mathrm{ft}$ altitude, native-tree forests of koa (Acacia koa) and ohia (Metrosideros polymorpha) exist. On Mauna Loa, at altitudes above $9,000 \mathrm{ft}$, conditions are dry and extensive forests are nonexistent.

\section{Climate}

The average annual air temperature of Hawaii ranges from about $73^{\circ} \mathrm{F}$ near the coast to less than $43^{\circ} \mathrm{F}$ near the summits of Mauna Kea and Mauna Loa (Nullet and Sanderson, 1993). The climate of the island of Hawaii is extremely diverse: lava deserts, tropical rain forests, and snow-capped mountain peaks all exist on the island. Using the Thornthwaite climatic classification, which considers the relation between precipitation 


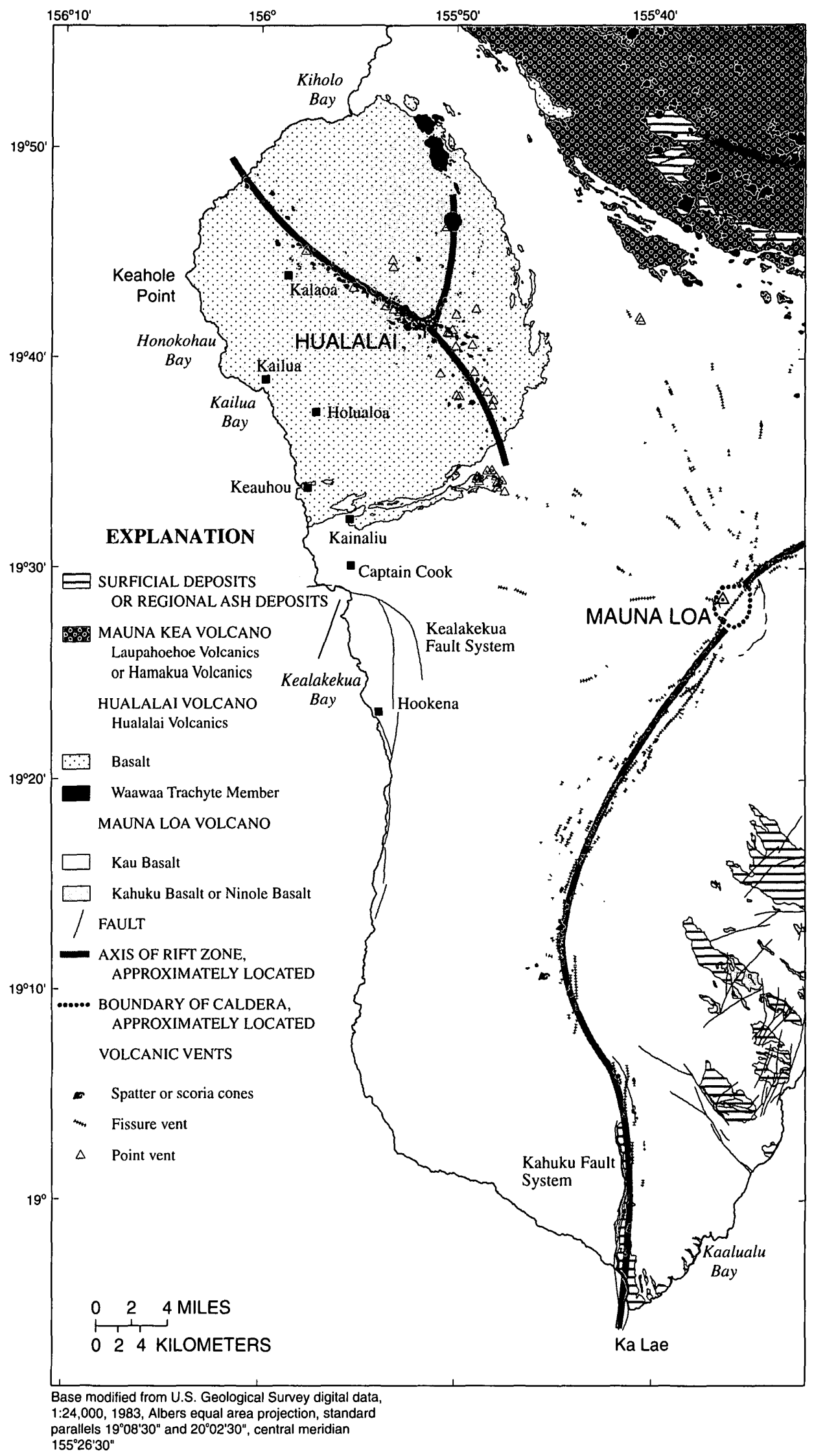

Figure 4. Generalized surficial geology of western Hawaii (modified from Wolfe and Morris, 1996). 
and potential evapotranspiration, Hawaii was found to have semiarid, subhumid, humid, and perhumid zones (Giambelluca and Sanderson, 1993).

In the Kona area, climate is controlled primarily by topography, a temperature inversion, and the location of the north Pacific anticyclone and other migratory systems relative to the island. The north Pacific anticyclone produces persistent northeasterly winds, known locally as tradewinds, in the vicinity of the Hawaiian islands. During the summer (May through September) tradewinds blow 80 to 95 percent of the time, and during the winter (October through April), when the highpressure ridge moves southward, tradewinds blow 50 to 80 percent of the time (Blumenstock and Price, 1967; Sanderson, 1993).

A temperature inversion, which marks the lower boundary of dry air subsiding in the north Pacific anticyclone, exists at a mean altitude of about $6,560 \mathrm{ft}$ over Hawaii (Schroeder, 1993). This inversion, commonly referred to as the tradewind inversion, greatly influences the climate and vegetation on mountain slopes in Hawaii. Diurnal and annual variability in climatic variables such as solar radiation, air temperature, and humidity, are affected by the altitude of the inversion (Giambelluca and Nullet, 1991). Because the inversion restricts upward flow of air (Mendonca and Iwaoka, 1969), an arid zone exists above an altitude of about $7,900 \mathrm{ft}$ where air is isolated from the oceanic moisture source (Giambelluca and Nullet, 1991).

Tradewinds are diverted around high mountain barriers, such as Mauna Kea and Mauna Loa, that extend above the inversion level. Because the Kona area is partly sheltered from the tradewinds by Mauna Loa and Mauna Kea, the daily weather in the Kona area is frequently dominated by a local, thermally driven wind. During the day, solar heating causes the air temperature above the land to exceed the air temperature above the ocean, which creates a pressure imbalance leading to a sea breeze. During the night, cooling of the land surface causes the air temperature above the ocean to exceed the air temperature above the land, which creates a pressure imbalance leading to a land breeze. In the Kona area, sea breezes converge with tradewinds that have passed through the saddle between Mauna Kea and Mauna Loa and over the upper slopes of Mauna Loa (Schroeder, 1993). Because the main rainfall-producing mechanism in the Kona area is related to the convergence of the sea breeze and the tradewinds, which are most persistent in the summer, rainfall in the Kona area is greatest in the summer months (Giambelluca and others, 1986). This is in contrast to most other areas throughout the State which have wet winters and dry summers. During the winter, migratory low-pressure systems bring heavy, widespread rains to the island.

\section{Previous Investigations}

The first comprehensive study of the water resources of the Kona area was conducted by Kimble (1915), who reported no perennial streams in the Kona area and six intermittent streams, the largest of which is Kiilae Stream (fig. 2). Kimble (1915) studied available surface-water and ground-water information, and recommended that a water system serving the zone between altitudes of 900 and 2,400 ft in the Kona area should consist of rainfall catchment and storage. Stearns and Macdonald (1946) provided a comprehensive description of the geohydrologic framework of Hawaii and compiled available ground-water and surface-water data, including chloride concentrations of water samples from dug wells, springs, and water holes in the Kona area. Taliaferro (1958) summarized the spatial and temporal variations of rainfall in the Kona area. Fischer and others (1966) used infrared images to identify the locations of coastal springs. Davis and Yamanaga (1968) described the surface-water and groundwater resources of the Kona area and concluded that more data were required to evaluate the potential for ground-water development in the area. Juvik and Ekern (1978) described the distribution of fog along transects on Mauna Loa and Hualalai and found that fog can contribute to the water balance of mountain areas on Hawaii.

The general geology of the island of Hawaii has been described by numerous investigators (see for example Stearns and Macdonald, 1946; Macdonald and others, 1983, Stearns, 1985). Langenheim and Clague (1987) described the stratigraphic framework of volcanic rocks on the island of Hawaii. Wolfe and Morris (1996) compiled a geologic map of Hawaii. Moore and others (1987) summarized geologic, petrologic, and geophysical data related to Hualalai Volcano.

Before the 1990 discovery of high ground-water levels in the Kona area, geophysical methods were used to evaluate the ground-water resources (Kauahikaua and others, 1985; Adams and others, 1969). Blackhawk 
Geosciences, Inc. (1991) reported on the results of a time domain electromagnetic (TDEM) geophysical survey in the vicinity of Palani Junction in which the inland limit of a geologic structure associated with high ground-water levels was delineated. Kauahikaua and others (1998) later completed a gravity survey of the Kona area to locate geologic structures, and identify the nature of these structures, that are related to the high water levels discovered in wells in the Kona area. Other geophysical studies on Hawaii include gravity (Kinoshita and others, 1963; Kinoshita, 1965), magnetic (Malahoff and Woollard, 1966; Hildenbrand and others, 1993), and seismic-refraction (Zucca and others, 1982; Hill and Zucca, 1987) surveys used to interpret the subsurface geology.

\section{GEOLOGY}

The evolution of Hawaiian volcanoes generally progresses through four stages--preshield, shield, postshield, and rejuvenated. However, not all Hawaiian volcanoes have a postshield stage or a rejuvenated stage. The preshield stage is the earliest, submarine phase of activity. Lava from the preshield stage consists predominantly of alkalic basalt (basalt that is low in silica and high in sodium and potassium). Lava from the principal stage of volcano building, called the shield stage, consists of fluid tholeiitic basalts (silica-saturated basalt) that characteristically form thin flows. This basalt forms during submarine, as well as subaerial, eruptions. A large central caldera can form during the preshield or shield stages and might later be partly or completely filled during subsequent eruptions. Thousands of lava flows erupt from the central caldera and from two or three rift zones that radiate out from the central part of the volcano. Intrusive dikes fed by rising magma extend down the rift zones and may erupt if they reach the surface. The shield stage is the most voluminous phase of eruptive activity during which more than 95 percent of the volcano is formed. The postshield stage is marked by a change in lava chemistry and character. Postshieldstage lava includes alkalic basalt, and more viscous hawaiite, ankaramite, mugearite, and trachyte. Lava from the postshield stage may erupt from locations outside of the rift zones formed during the shield stage and forms a veneer atop the shield-stage basalt. After a period of quiescence, lava might issue from isolated vents on the volcano during the rejuvenated stage.
The volcanic rocks in the Kona area can be divided into three main groups on the basis of modes of emplacement: lava flows, dikes, and pyroclastic deposits. In general, lava flows that erupt from rift zones are less than $10 \mathrm{ft}$ thick and are either pahoehoe, which is characterized by smooth, ropy surfaces, or aa, which contains a massive central core typically sandwiched between rubbly clinker layers. Aa flows are typically more abundant at greater distances from eruptive sources (Lockwood and Lipman, 1987). Mauna Loa contains about equal proportions of aa and pahoehoe (Lockwood and Lipman, 1987).

Dikes are thin, near-vertical sheets of massive rock that intrude existing rocks, commonly lava flows. Dikes are commonly exposed by erosion within the rift zones of older volcanoes (see for example Takasaki and Mink, 1985), including Kohala on the island of Hawaii.

Because Mauna Loa and Hualalai have not been significantly dissected, dikes are generally not exposed on these volcanoes. On Mauna Loa, some dikes have been exposed in the walls of the central caldera and in craters near the summit (Stearns and Macdonald, 1946, p. 96). Evidence from volcanoes on other Hawaiian islands suggests that dikes associated with the rift zones of Mauna Loa and Hualalai are probably most abundant within the central part of the rift zones.

The dikes and the rocks they intrude are collectively referred to as dike complexes. In the central part of a rift zone, the number of dikes can be as many as 1,000 per mile of horizontal distance across the zone (Takasaki and Mink, 1985). The number of dikes decreases toward the outer edges of a rift zone. Within the central part of a dike complex, the dike rocks typically compose 10 percent or more of the total rock volume. At the outer part of the dike complex, within the marginal dike zone, dikes usually constitute less than 5 percent of the total rock volume (Takasaki and Mink, 1985). Wentworth and Macdonald (1953) estimate that 200 dikes are needed to build $1,000 \mathrm{ft}$ of a shield volcano.

Pyroclastic rocks are rocks that form by explosive volcanic activity and that are deposited by transport processes related to this activity. Pyroclastic rocks, such as ash, cinder, and spatter, can be deposited during all of the subaerial stages of eruption but probably form less than 1 percent of the mass of a Hawaiian volcano (Wentworth and Macdonald, 1953). 
The island of Hawaii is formed primarily by the shield-stage volcanic rocks of Mauna Loa and Kilauea and the shield- and postshield-stage volcanic rocks of Kohala, Hualalai, and Mauna Kea (Langenheim and Clague, 1987). Volcanic rocks from Hualalai and Mauna Loa cover the Kona study area (fig. 4).

\section{Hualalai Volcano}

The primary rift zones of Hualalai trend northwest and south-southeast, emanate from near the summit of the volcano, and are marked by numerous cinder and spatter cones (fig. 4). A third, less well-defined rift zone extends north from the summit of Hualalai (Macdonald and others, 1983; Moore and others, 1987). The subaerial part of the northwest rift zone is 1.2 to $2.5 \mathrm{mi}$ wide and $15 \mathrm{mi}$ long. The submarine part of the northwest rift zone may extend about $43 \mathrm{mi}$ offshore. The southsoutheast rift zone is 1.9 to $3.1 \mathrm{mi}$ wide and about $8 \mathrm{mi}$ long (Moore and others, 1987). There is no direct evidence that a caldera ever existed on Hualalai (Macdonald and others, 1983). Magnetic lows, which are probably related to rocks that have been chemically altered by hydrothermal fluids, exist near the three rift zones (Hildenbrand and others, 1993). A positive gravity anomaly (fig. 5) exists near, but is somewhat west of, the south-southeast rift zone of the volcano (Kinoshita and others, 1963; Kinoshita, 1965). Zucca and others (1982) analyzed gravity and seismic-refraction data, and indicated that a dense structure with high seismic velocity lies parallel to the Kona coast in the vicinity of the positive gravity anomaly and probably represents a buried rift zone.

The entire subaerial surface of Hualalai consists of postshield-stage alkalic basalt, with minor hawaiite and trachyte, collectively named the Hualalai Volcanics (Wolfe and Morris, 1996; Langenheim and Clague, 1987). Although the shield-stage tholeiitic basalt of Hualalai is not exposed on the land surface, submarine samples from dredges (Clague, 1982) and samples from drilled wells (Moore and others, 1987; Clague, 1987) have contained tholeiitic rocks. Clague (1987) reported that a well (presumably Huehue Ranch well 4559-01; fig. 3) near the northwest rift zone of Hualalai penetrated about $1,000 \mathrm{ft}$ of alkalic basalt flows before penetrating trachyte overlying tholeiitic basalt. In addition, tholeiitic basalt possibly originating from Hualalai was found about $250 \mathrm{ft}$ below the ground surface at Kahaluu shaft (well 3557-05) (Clague, 1987). The Waawaa Trachyte Member of the Hualalai Volcanics consists of a trachyte cone (Puu Waawaa, fig. 1) and trachyte flow. On the flanks of Hualalai, mapped dips of the Hualalai Volcanics are typically about $2^{\circ}$ to $15^{\circ}$ (Stearns and Macdonald, 1946).

The Hualalai Volcanics ranges in age from Pleistocene to Holocene. The oldest exposed basalt flow of the Hualalai Volcanics is at least 13,000 years old (Wolfe and Morris, 1996). The youngest rocks from Hualalai are from an 1801 flow originating from the northwest rift zone. Funkhouser and others (1968) published a potassium-argon age of $0.4 \pm 0.3 \mathrm{Ma}$ (million years) for the Waawaa Trachyte Member, and Langenheim and Clague (1987) report an age of about 0.105 Ma.

\section{Mauna Loa Volcano}

The primary rift zones of Mauna Loa trend roughly southwest and northeast and extend from near the summit caldera of the volcano. Both the southwest and northeast rift zones are marked by numerous fissure vents (fig. 4). In addition, positive gravity anomalies that extend from near the summit region (Kinoshita and others, 1963; Kinoshita, 1965) (fig. 5) suggest the presence of dense, intrusive dikes associated with the southwest and northeast rift zones. Magnetic anomalies also have been measured in the vicinity of the two primary rift zones (Hildenbrand and others, 1993). The northwest flank of Mauna Loa contains at least 60 linear eruptive features oriented radially to the summit. These radial vents are generally marked by linear curtain-offire ramparts (Lockwood and Lipman, 1987). In addition, vents associated with an 1877 submarine eruption exist offshore near Kealakekua Bay (Fornari and others, 1980; Moore and others, 1985; Moore and Clague, 1987).

All of the exposed volcanic rocks of Mauna Loa are shield-stage tholeiitic basalt. In the Kona area, the shield-stage volcanic rocks from Mauna Loa were named the Kau Basalt, which consists of tholeiitic basalt, olivine tholeiitic basalt, and picritic tholeiitic basalt (Wolfe and Morris, 1996; Langenheim and Clague, 1987). On the western flank of Mauna Loa, mapped dips of the Kau Basalt are typically about $3^{\circ}$ to $10^{\circ}$ (Stearns and Macdonald, 1946). Some of the Kau 
Upolu Point

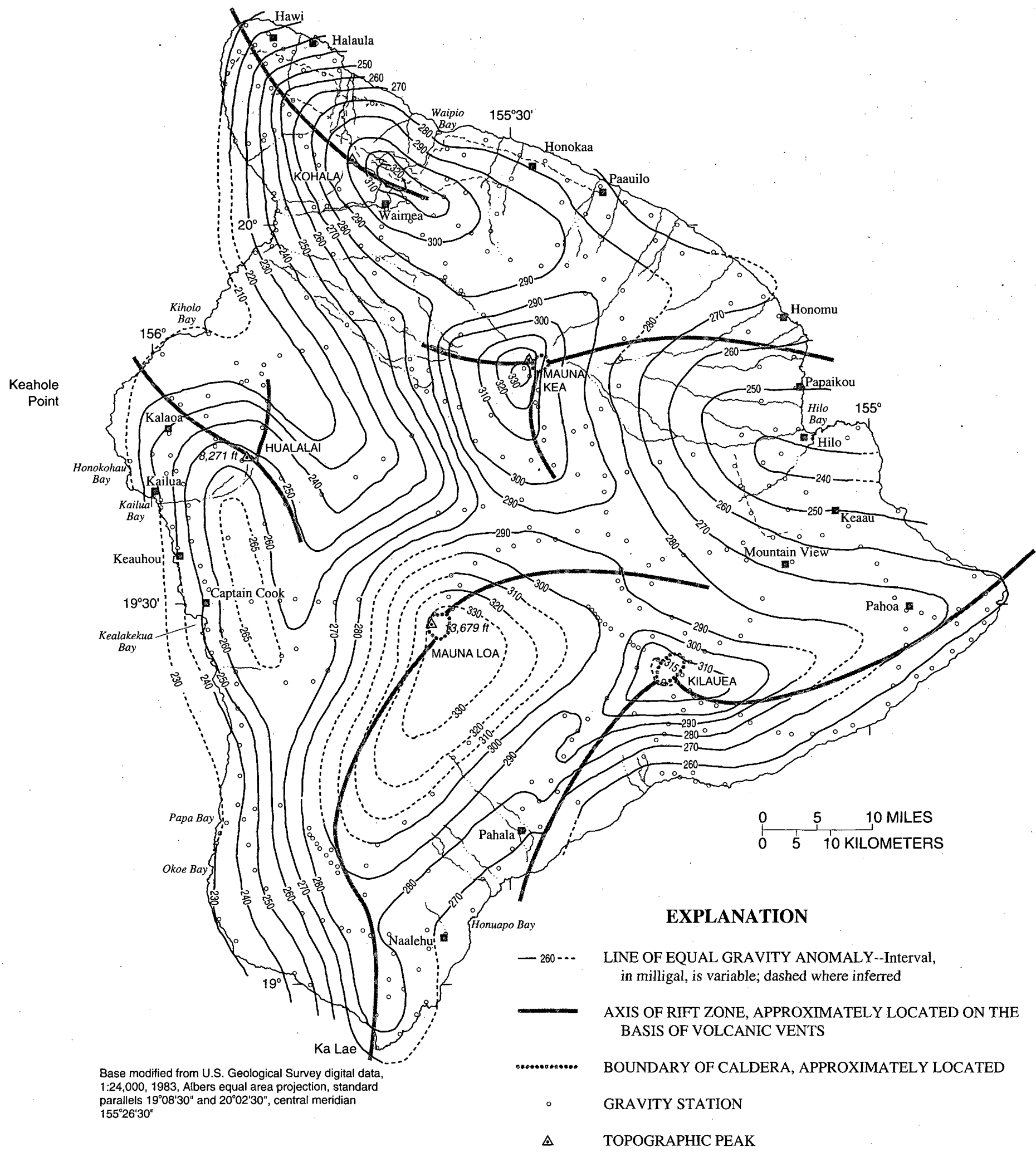

Figure 5. Bouger gravity anomaly map, island of Hawaii (modified from Kinoshita and others, 1963). 
Basalt interfingers with and overlies Hualalai Volcanics (Stearns and Macdonald, 1946, p. 76, 139). The Kau Basalt ranges in age from Pleistocene to Holocene.

\section{Coastal Deposits}

Coastal deposits in the Kona area are limited. Terrestrial sediments in particular are limited in extent because little erosion has taken place. Several drowned carbonate reefs exist off the west coast of Hawaii (Moore and Szabo, 1986; Clague, 1987). The youngest carbonate reef drowned 13,000 years ago and exists 500 ft below sea level (Moore and Fornari, 1984; Moore and Clague, 1987). The reef is covered in places by younger lava flows from both Hualalai and Mauna Loa. The next deeper reef is about $1,300 \mathrm{ft}$ below sea level and has an age of about 120,000 years (Szabo and Moore, 1986).

\section{Faults}

Mass-wasting deposits related to prodigious submarine landslides have been identified off the Kona coast using sonar images (Lipman and others, 1988; Moore and others, 1989). Debris avalanches in the Kona area moved about $60 \mathrm{mi}$ from their source near the present shoreline to depths of about 16,000 ft (Moore and others, 1989). The subaerially exposed Kealakekua and Kahuku fault systems (fig. 4) are associated with large-scale submarine landslides in the Kona area. There may be additional onshore faults in the Kona area that have been buried by younger lava flows.

\section{HYDRAULIC CONDUCTIVITY OF THE ROCKS}

Hydraulic conductivity is a quantitative measure of the capacity of a rock to transmit water (see for example Domenico and Schwartz, 1990). Few published estimates exist for the hydraulic conductivity of volcanic rocks in the Kona area of Hawaii. In qualitative terms, permeability describes the ease with which fluid can move through a porous rock (see for example Domenico and Schwartz, 1990). The permeability of volcanic rocks is variable and depends mainly on the mode of emplacement of the rocks.

\section{Lava Flows}

In a layered sequence of subaerial, shield-stage lava flows along the flanks of a volcano, where dike intrusions are not present, the overall permeability is high (Stearns and Macdonald, 1946). The main features of lava flows contributing to the high permeability are (1) clinker zones associated with aa flows, (2) voids along the contacts between flows, (3) cooling joints normal to flow surfaces, and (4) lava tubes associated with pahoehoe flows. In volcanic-rock aquifers composed of mainly flat-lying lava flows, the hydraulic conductivity is greatest parallel to the direction of the flows, and is least perpendicular to the layered sequence of flows. On the island of Oahu, the horizontal hydraulic conductivity of the volcanic-rock aquifer has been estimated to be 200 times greater than the vertical hydraulic conductivity (Souza and Voss, 1987). In general, trachyte flows on Hualalai are poorly permeable (Stearns and Macdonald, 1946) and form confining units in some areas.

Nance (1991) estimated the hydraulic conductivity of the volcanic rocks near Keahole Point using measured ground-water level variations caused by ocean tides. Nance (1991) reported a range of horizontal hydraulic-conductivity values of 500 to $33,900 \mathrm{ft} / \mathrm{d}$. For the area between Kiholo Bay and Kawaihae Bay, Kanehiro and Peterson (1977) estimated a horizontal hydraulic-conductivity value of $9,100 \mathrm{ft} / \mathrm{d}$ from the estimated ground-water flow rate and head gradient. Kanehiro and Peterson (1977) also used measured ground-water-level variations caused by ocean tides to estimate a range of horizontal hydraulic-conductivity values from 3,400 to $12,600 \mathrm{ft} / \mathrm{d}$.

\section{Dikes}

Although most dikes are typically less than $10 \mathrm{ft}$ thick, dikes are hydrologically important because they have low permeability and can extend vertically and laterally for thousands of feet. Within a dike complex, dikes intersect at various angles and compartmentalize the more permeable intruded rock in which ground water can be impounded to high altitudes. Because dikes lower overall rock porosity and permeability, the average hydraulic conductivity of a dike complex decreases as the number of dike intrusions increases. In addition, hydraulic conductivity is expected to be 
higher in a direction along the strike of the dikes rather than perpendicular to the strike.

Meyer and Souza (1995) used a numerical model to estimate that the average effective horizontal hydraulic conductivity of a dike complex ranges from about 0.01 to $0.1 \mathrm{ft} / \mathrm{d}$. These values reflect the influence of both the intrusive dikes as well as the lava flows between dikes. The hydraulic conductivity of the intrusive dike material was estimated to range from $10^{-5}$ to $10^{-2} \mathrm{ft} / \mathrm{d}$ (Meyer and Souza, 1995). Williams and Soroos (1973) published analyses of aquifer tests conducted in areas with dikes on the islands of Oahu, Molokai, and Maui, but no estimates were made of the effective hydraulic conductivity of the dike complexes.

\section{Pyroclastic Deposits}

The permeability of pyroclastic deposits, which are commonly granular, depends on grain size and degree of sorting. Coarse deposits, such as cinder, are generally more permeable than fine ash. Takasaki and Mink (1982) estimated that the hydraulic conductivity of pyroclastic deposits of southeast Oahu generally ranges from 1 to $500 \mathrm{ft} / \mathrm{d}$. No estimates are available for the hydraulic conductivity of pyroclastic deposits in the Kona area.

\section{Weathering}

Weathering tends to reduce the permeability of volcanic rocks. The reduction of permeability may be attributed to secondary mineralization which clogs the original open spaces, or clays and colloids that precipitate from percolating water (Mink and Lau, 1980). A hydraulic-conductivity value of $0.058 \mathrm{ft} / \mathrm{d}$ was estimated from an injection test conducted in weathered basalt on Oahu (R.M. Towill Corporation, 1978). Wentworth (1938) conducted laboratory permeameter tests on core samples and estimated the hydraulic conductivity of weathered basalt to be between 0.083 and 0.128 $\mathrm{ft} / \mathrm{d}$. Miller (1987) used the water-retention characteristics of core samples collected in central Oahu to estimate the saturated hydraulic conductivity of weathered basalt and found values ranging from 0.0028 to $283 \mathrm{ft} / \mathrm{d}$. The wide range of hydraulic-conductivity values estimated by Miller (1987) was attributed to the variability in macroporosity among samples.
Poorly permeable weathered ash zones may exist between lava flows. These weathered zones likely impede the flow of ground water wherever they exist. Because the thickness and areal extent of weathered zones are largely unknown, the overall hydrologic significance of these zones cannot be determined.

\section{GEOLOGIC ORIGIN OF HIGH WATER LEVELS}

Wells with measured water levels higher than $40 \mathrm{ft}$ above sea level have been drilled in the area between Kalaoa and Honaunau at land surface altitudes of about $1,600 \mathrm{ft}$. Ground-water levels are substantially higher in this area than in the downgradient part of the aquifer near the coast. The abrupt rise in water levels indicates that a major hydrogeologic feature, trending approximately north-south, exists inland of the coastal, dikefree part of the aquifer and impedes the flow of ground water. The geologic nature of the structure or structures associated with the high water levels in the Kona area is unknown. The high water levels may be associated with buried, low-permeability rocks in the form of dikes, lava-draped fault scarps, or massive lava flows (fig. 6).

Gravity and seismic-refraction data (Zucca and others, 1982) indicate that a dense structure with high seismic velocity, such as a buried dike complex, may exist where high water levels have been measured. Low permeability dikes can impede the seaward flow of ground water and impound water to high levels (fig. 6A). The water table is generally at different altitudes within the different compartments that are formed by the dikes.

Fault scarps draped by subsequent lava flows (fig. 6B) represent another possible explanation for the presence of high water levels in the Kona area (Kauahikaua, 1993). The hydraulic conductivity of a lava flow in the direction perpendicular to the flow surface is generally less than the hydraulic conductivity in the longitudinal and transverse directions of the lava flow. Thus, lava draped over a subvertical fault scarp can create an impediment to horizontal ground-water flow. In addition, offsetting of lava flows caused by faulting could reduce overall permeability of the volcanic rocks in the plane of the lava flows.

Kauahikaua and others (1998) modeled gravity profiles in the Kona area and suggested that westward- 


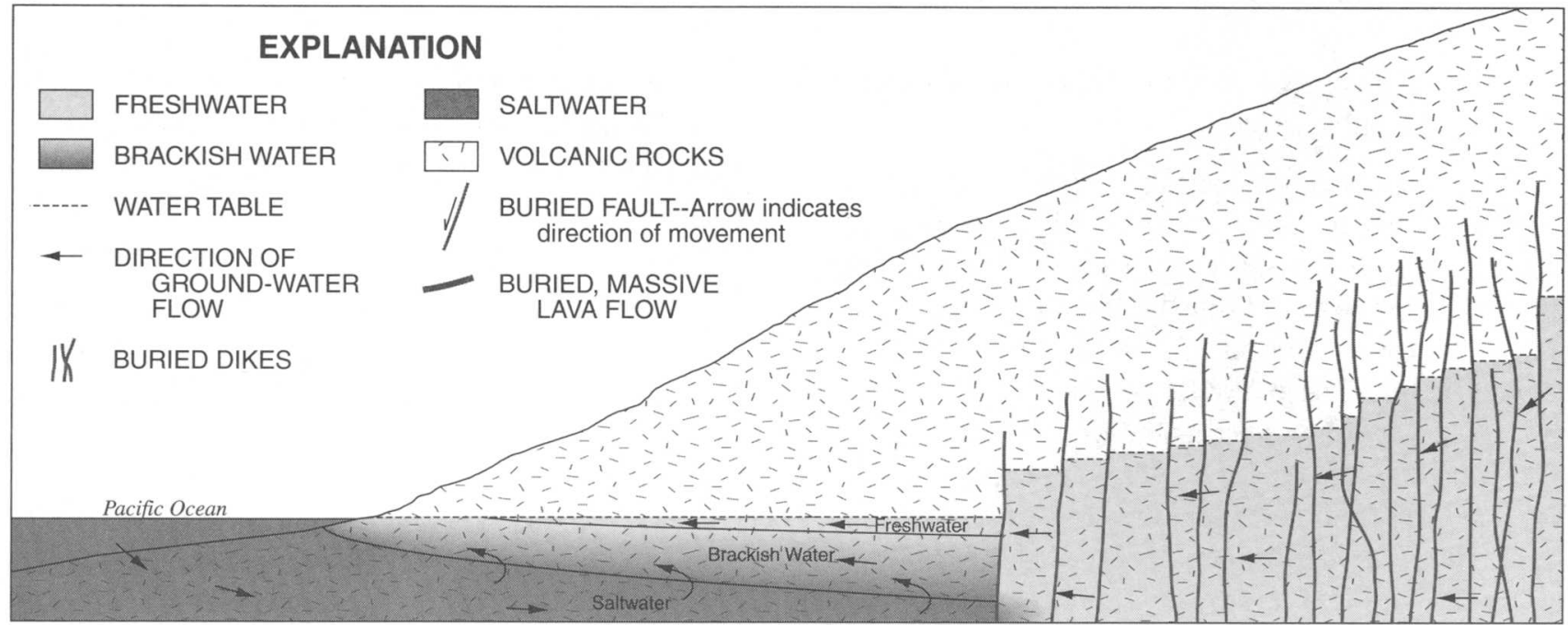

B

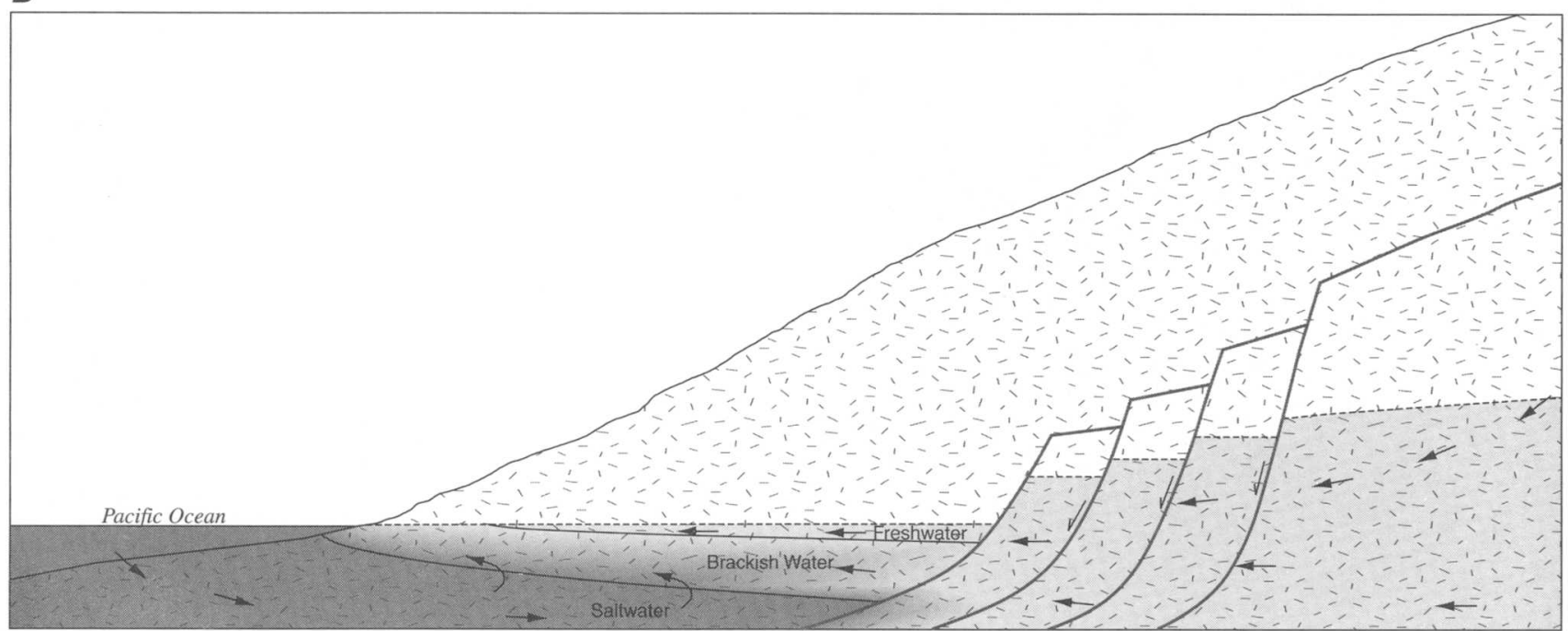

C

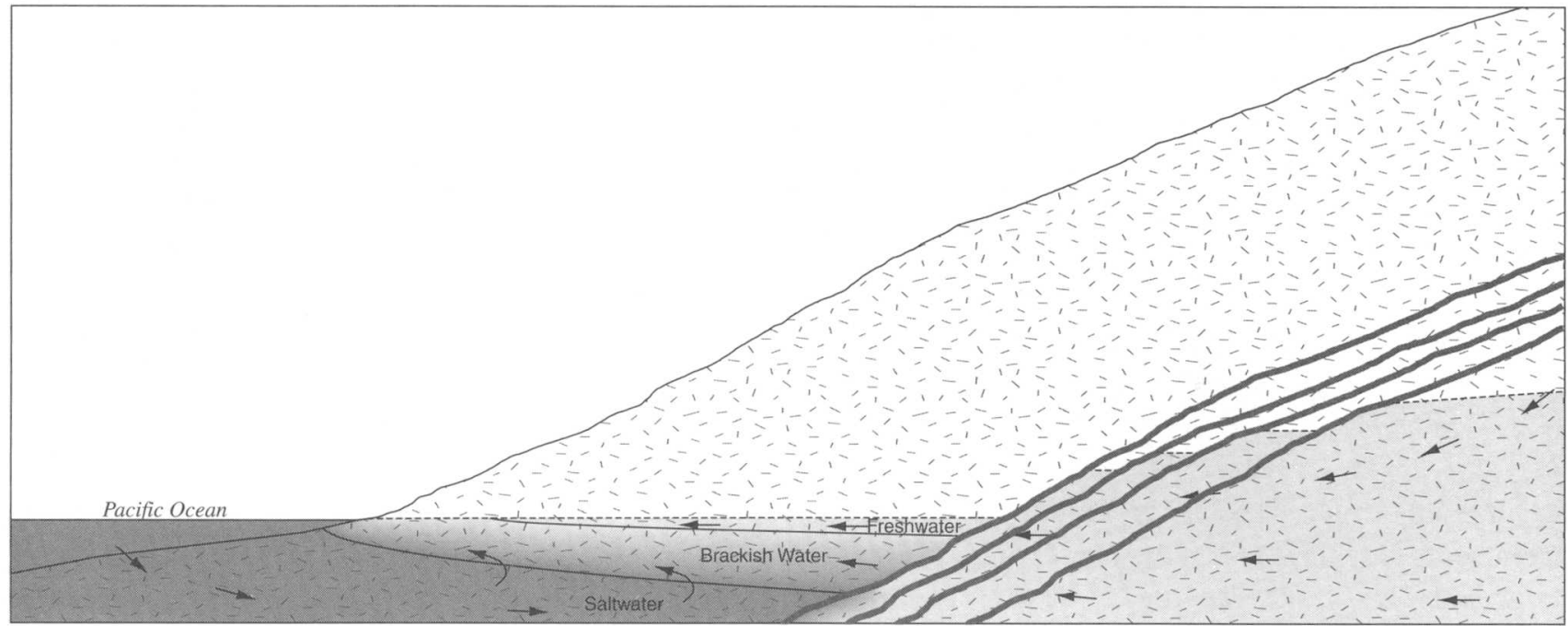

Figure 6. Schematic cross sections showing geologic structures that may be impounding ground water to high levels (greater than 40 feet above sea level) in the Kona area, island of Hawaii: $(\boldsymbol{A})$ buried dike complex; $(\boldsymbol{B})$ buried fault system; (C) buried, massive lava flows. 


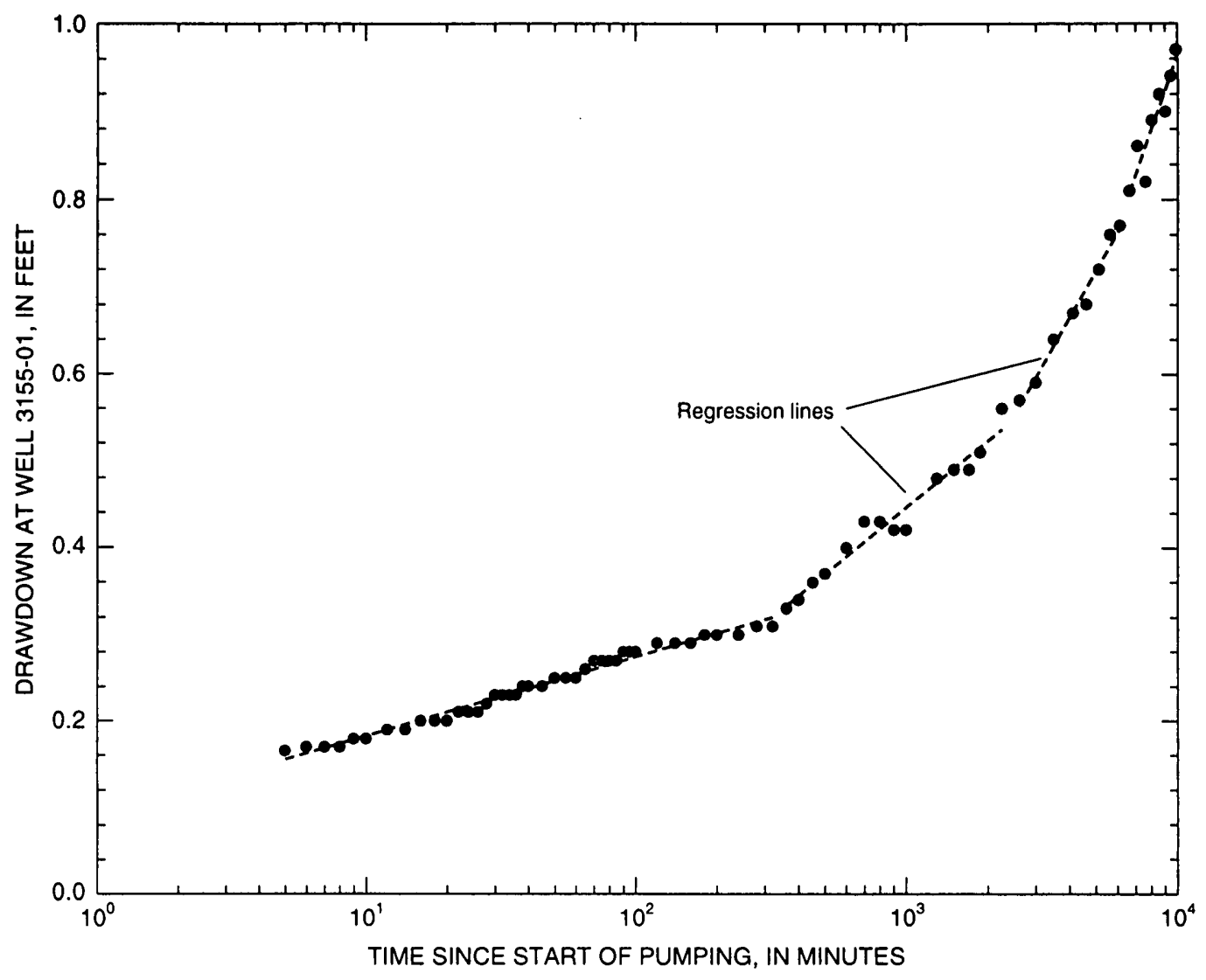

Figure 7. Drawdown as a function of time at well 3155-01 during an aquifer test starting May 24, 1993, Kona, island of Hawaii. Well 3155-02, located about 34 feet from observation well 3155-01, was pumped at a sustained rate of about 1,230 gallons per minute.

dipping trachyte flows may be responsible for impeding ground-water flow and creating high water levels (fig. 6C). Low-permeability trachyte can form confining units and may be responsible for creating artesian conditions in some areas. The water level in State Hualalai exploratory well 4258-03 rose from $190.70 \mathrm{ft}$ on August 5, 1993 to $292.44 \mathrm{ft}$ on October 7,1993 after the well penetrated material characterized as trachyte (Glenn Bauer, 1993, unpub. geologic log in CWRM well file).

Although the geologic nature of the structure associated with the high water levels in the Kona area is unknown, aquifer tests have provided some insight into the hydrogeologic characteristics of the structure. One test was done from May 24 to 31, 1993 (unpub. data, USGS Hawaii District well files), when the State Halekii well 3155-02 (fig. 3) was pumped at a rate of about $1,225 \mathrm{gal} / \mathrm{min}$ and USGS Halekii well 3155-01, located about $34 \mathrm{ft}$ from the pumped well, was used as an observation well. A semilogarithmic plot of drawdown as a function of time (fig. 7) at the observation well, with time plotted on the logarithmic scale, shows changes in slope that are typically associated with ground-water barriers (see for example Ferris and others, 1962). This aquifer test, and other similar tests done in the Kona area, indicate that the aquifer has a compartmental nature that could be related to the presence of dikes. Results from the test alone do not rule out the possibility that the structure may be related to faulting. However, a buried dike complex is most consistent with all the available hydrologic and geophysical evidence. There is a possibility that faults or low-permeability lava flows may exist in combination with a buried dike complex.

\section{WATER BUDGET}

Freshwater in the Kona area is derived mainly from rain, snow, and intercepted cloud vapor that 
precipitates as fog drip. The precipitation either (1) runs off, (2) evaporates or is transpired by vegetation, or (3) recharges the ground-water system.

Because data are unavailable to compute a detailed water budget using a daily or even a monthly time interval, recharge in the Kona area was estimated for this study using a steady-state annual water budget of the form:

$$
G=P+F-R-E
$$

where:

$G=$ average annual ground-water recharge $[\mathrm{L} / \mathrm{T}]$,

$P=$ average annual precipitation (excludes fog drip) $[\mathrm{L} / \mathrm{T}]$,

$F=$ average annual fog drip $[\mathrm{L} / \mathrm{T}]$,

$R=$ average annual runoff $[\mathrm{L} / \mathrm{T}]$, and

$E=$ average annual evapotranspiration $[\mathrm{L} / \mathrm{T}]$.

\section{Precipitation}

Precipitation, mainly in the form of rainfall, in the Kona area is characterized by a maximum between altitudes of 2,000 and 3,000 ft, and minima near the summits of Mauna Loa and Hualalai (fig. 8). Near the coast, mean annual rainfall is 20 to 40 in. For comparison, mean annual rainfall over the open ocean is estimated to be between 21.7 in. and 27.6 in. (Elliot and Reed, 1984; Dorman and Bourke, 1979).

The thermally induced sea breeze in the Kona area causes warm, moisture-laden air from over the ocean to flow inland. Warm air that is orographically lifted up the slopes of Mauna Loa and Hualalai is cooled, and this frequently results in cloud formation and rainfall during the afternoon hours. In the Kona area, maximum rainfall of about $80 \mathrm{in} / \mathrm{yr}$ is measured between altitudes of 2,000 and 3,000 ft (Giambelluca and others, 1986).

Descending air above the temperature inversion is dry, and thus, clouds that penetrate the inversion rapidly evaporate (Schroeder, 1993). At the summit of Mauna Loa, which is above the temperature inversion, precipitation is about 20 in. (Giambelluca and others, 1986).

Most of the precipitation near the summit is in the form of snow or hail (Schroeder, 1993).

Near the coast, at an altitude of $10 \mathrm{ft}$, annual rainfall at rain gage 68 (fig. 8) ranged from about 15 to 51 in. during 1918-78 (fig. 9). Farther upslope, at an altitude of $1,500 \mathrm{ft}$ near Kainaliu, annual rainfall at rain gage 73.2 (fig. 8) ranged from about 40 to 94 in. during 1931-83 (fig. 9). At an altitude of $4,850 \mathrm{ft}$, annual rainfall at rain gage 73 (fig. 8) ranged from about 11 to 48 in during 1923-82 (fig. 9). The annual rainfall cycle at station 73.2 reflects a summertime maximum (fig. 9).

\section{Fog Drip}

Although mountain fog frequently develops in association with convective rainfall in the Kona area, fog can also form in the absence of rainfall (Juvik and Ekern, 1978). On the slopes of Mauna Loa and Hualalai, ground-water recharge from infiltration of rainfall can be enhanced by intercepted cloud vapor that precipitates as fog drip. Fog develops predominantly in the afternoon hours of the day (Juvik and Ekern, 1978) and can be intercepted by vegetation and the ground surface.

Juvik and Ekern (1978) used louvered-screen fog gages (McKnight and Juvik, 1975) to estimate fog drip in the Kona area and developed the following linear regression equation that describes the relation between the fog-to-rain ratio and altitude:

$$
\begin{gathered}
F=0.1776(0.3048 / 1000) z-0.1229 \text { for } z>2,270 \mathrm{ft}(2) \\
F=0 \text { for } z \leq 2,270 \mathrm{ft}
\end{gathered}
$$

where:

$F$ is the ratio of fog to rain, and

$z$ is altitude in feet.

(Note that $z$ in the original equation was expressed in terms of kilometers. Also note that the $y$-intercept in the original equation should be a negative value.) Because data indicate that there is very little cross-slope fog variation, the altitudinal model developed by Juvik and Ekern (1978) adequately describes the distribution of fog in the Kona area.

In developing equation 2, Juvik and Ekern (1978) expressed fog values in terms of unit vertical catch by dividing the intercepted fog values by a factor of 5 , which represents the ratio of the surface area of the cylindrical fog gage to the cross-sectional area of the rain gage. The factor of 5 is probably most appropriate for sites having omnidirectional exposure to clouds, such as at the summit of Hualalai. More recently, Juvik and Nullet (1995) studied fog on the southwest slope of Mauna Kea and divided the intercepted fog values by a factor of 2.83, which represents the ratio of the projected vertical area of the cylindrical fog gage to the 


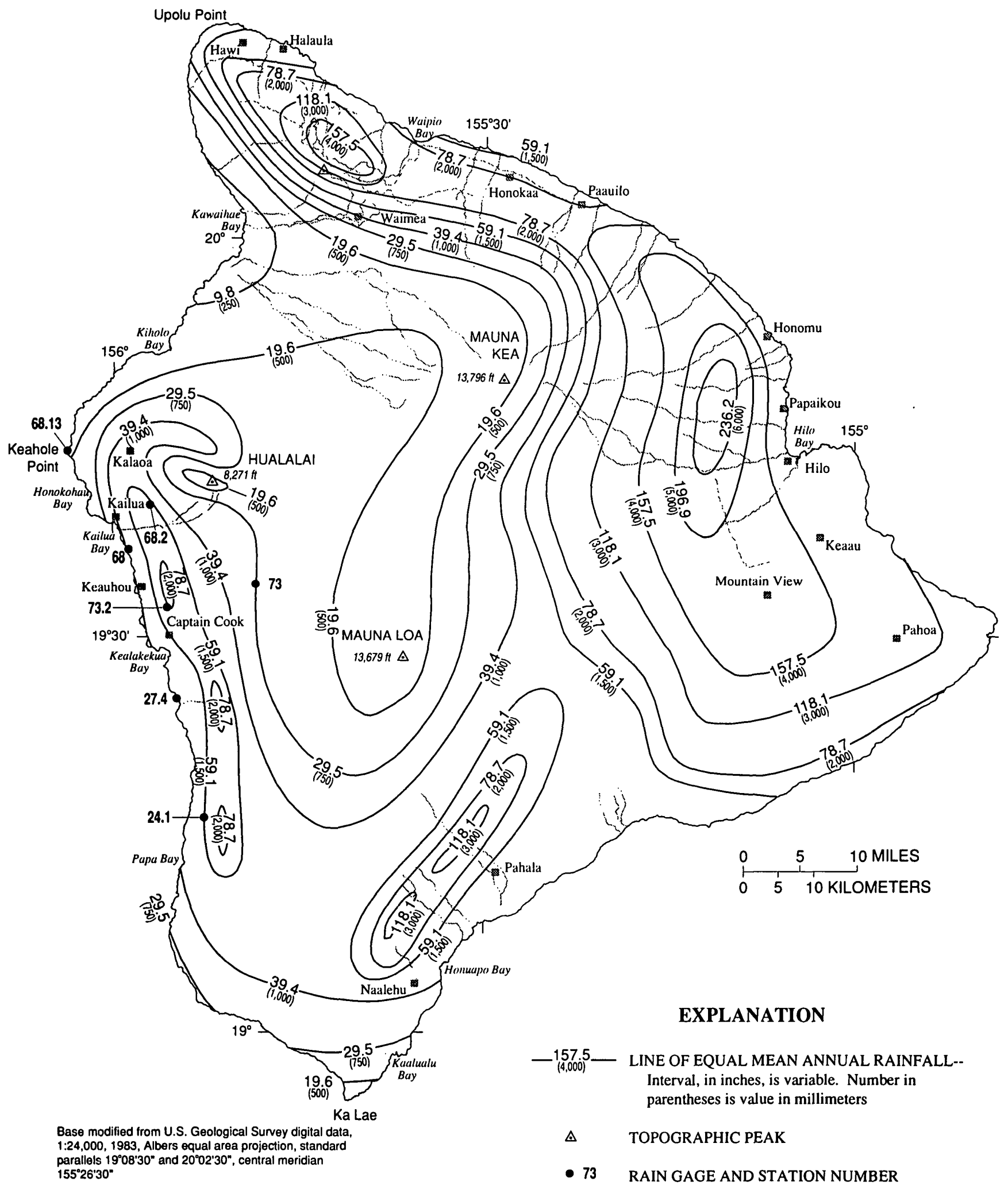

Figure 8. Mean annual rainfall, island of Hawaii (modified from Giambelluca and others, 1986). 

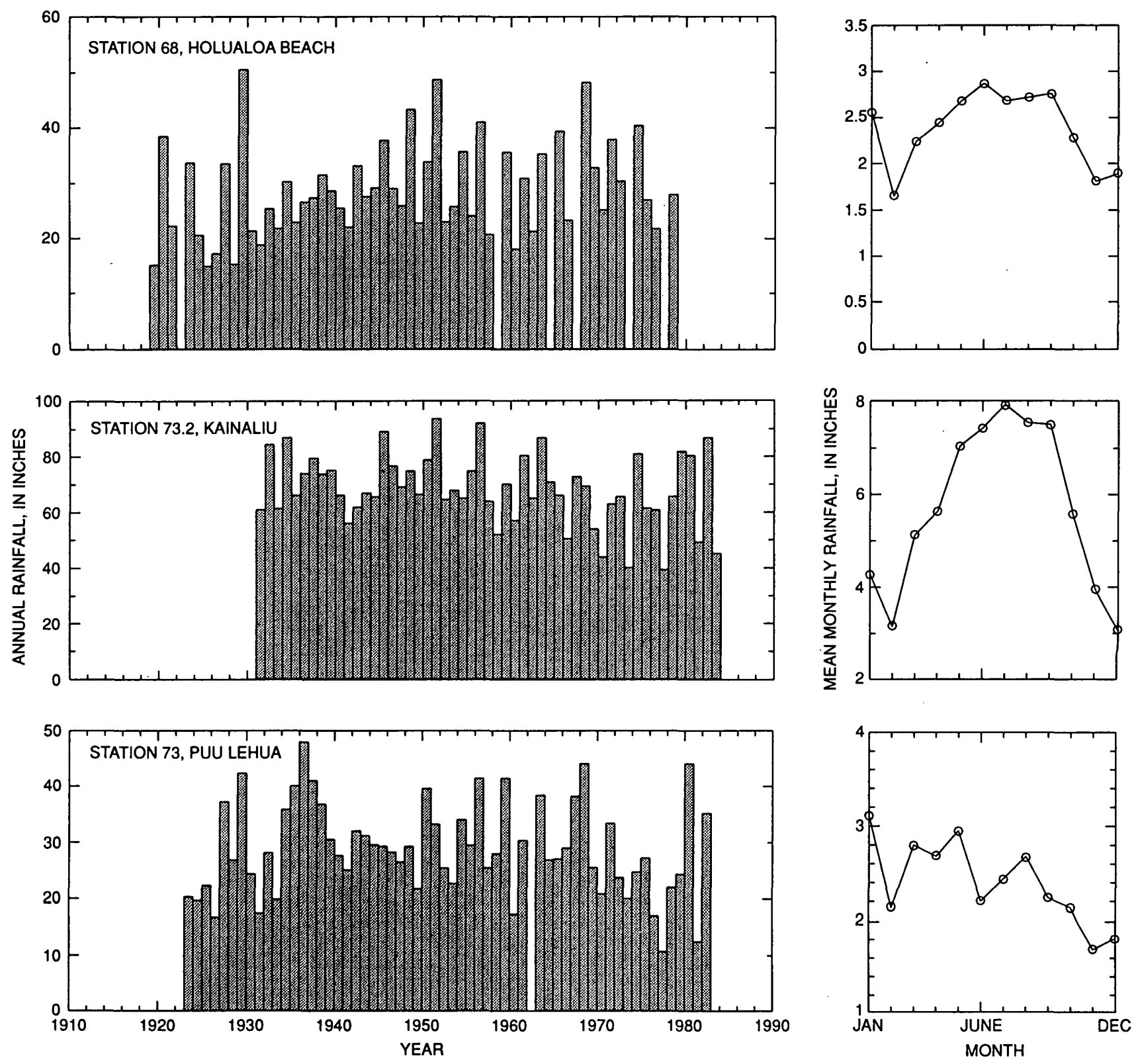

Figure 9. Annual and mean monthly rainfall at stations $68,73.2$, and 73 (locations are shown on figure 8 ), Kona, island of Hawaii. Years with annual rainfall shown as zero represent missing data. Annual rainfall from Commission on Water Resource Management files, and mean monthly rainfall from Giambelluca and others (1986). 
Table 1. U.S. Geological Survey continuous-record surface-water stations, Kona, island of Hawaii [Mgal/d, million gallons per day]

\begin{tabular}{ccccc}
\hline Station & Station name & Period of record & $\begin{array}{c}\text { Average } \\
\text { discharge } \\
\text { (Mgal/d) }\end{array}$ & $\begin{array}{c}\text { Days of zero } \\
\text { discharge } \\
\text { (percent) }\end{array}$ \\
\hline 16759200 & Right Branch Waiaha Stream near Holualoa & $5 / 60-9 / 82$ & 0.21 & 30 \\
16759300 & Waiaha Stream at Luawai near Holualoa & $5 / 60-9 / 71$ & 0.60 & 40 \\
16759500 & Waiaha Stream near Holualoa & $1 / 58-9 / 68$ & 0.71 & 52 \\
16759800 & Kiilae Stream near Honaunau & $5 / 58-9 / 82$ & 0.14 & 38 \\
\hline
\end{tabular}

cross-sectional area of the rain gage. Similar gages were used by Juvik and Ekern (1978) and Juvik and Nullet (1995). Because rainfall and fog on the western slope of Mauna Loa are almost exclusively associated with the upslope wind (Juvik and Ekern, 1978), it is reasonable to assume that the fog intercepted by the gage is related to the projected vertical area of the gage as opposed to the entire surface area. Thus, the relation between the fog-to-rain ratio and altitude (equation 2) can be adjusted by a factor of $5 / 2.83$ to provide a more representative estimate of fog drip (J.O. Juvik, University of Hawaii at Hilo, oral commun., 1998):

$$
\begin{gathered}
F=(5 / 2.83)[0.1776(0.3048 / 1000) z-0.1229] \\
\text { for } z>2,270 \mathrm{ft} \\
F=0 \text { for } z \leq 2,270 \mathrm{ft}
\end{gathered}
$$

\section{Runoff}

No perennial streams flow in the Kona area. Although shallow water courses do exist on the slopes of Mauna Loa and Hualalai, runoff does not reach the ocean except after intense rainfall (Davis and Yamanaga, 1968). Using an equation relating annual rainfall and annual runoff, Giambelluca and Sanderson (1993, figs. 4.2 and 4.5), estimated annual runoff in the Kona area to be about 5 to 10 percent of the annual rainfall.

The USGS maintained continuous-record surfacewater stations at four sites in the Kona study area on Kiilae and Waiaha Streams (fig. 2). By the end of 1982, all four of the continuous-record surface-water stations had been discontinued (Fontaine, 1996) (table 1).

Flow in Kiilae Stream normally begins in a marshy forested area at an altitude of about 3,200 ft (Davis and Yamanaga, 1968). The average flow of Kiilae Stream at station 16759800 (gage altitude $2,898 \mathrm{ft}$ ) was 0.14 $\mathrm{Mgal} / \mathrm{d}$ during the period 1958-82, and peak discharge was reported to be $67 \mathrm{Mgal} / \mathrm{d}$ (Chinn and others, 1983). The stream has no flow about 38 percent of the time. During the period July 1962 to June 1963, Davis and Yamanaga (1968) estimated that discharge accounted for probably less than 10 percent of the rainfall in the drainage basin.

Flow of the Right Branch of Waiaha Stream at an altitude of $3,280 \mathrm{ft}$, above any diversions, was measured at station 16759200 and averaged $0.21 \mathrm{Mgal} / \mathrm{d}$ during the period 1960-82 (Chinn and others, 1983). The reported peak discharge was $1,050 \mathrm{Mgal} / \mathrm{d}$ (Chinn and others, 1983). At stations 16759300 and 16759500 , measured discharge was affected by upstream diversions.

\section{Evaporation}

Over the open ocean, the computed evaporation rate is about $65 \mathrm{in} / \mathrm{yr}$ (Seckel, 1962). Near the coast in the Kona area, the mean annual pan-evaporation rate was estimated to be about 60 to 80 in. (fig. 10) (Ekern and Chang, 1985). Evaporation profiles on Mauna Loa (Bean and others, 1994) indicate that the evaporation rate decreases with altitude from sea level to about $3,900 \mathrm{ft}$, and then increases with altitude above $3,900 \mathrm{ft}$. At an altitude of 3,900 ft, an average pan-evaporation rate of $27 \mathrm{in} / \mathrm{yr}$ was estimated from atmometer measurements. At an altitude of $11,150 \mathrm{ft}$, the average pan-evaporation rate was $88 \mathrm{in} / \mathrm{yr}$.

Near lowland coastal areas, evaporation rates are generally high because of positive heat advection from both oceanic and land sources (Nullet and Giambelluca, 1990). Fog associated with the sea breeze reduces solar radiation and increases humidity, and this results in minimum rates of evaporation on the lower slopes of Mauna Loa at an altitude of about 3,900 ft. Between altitudes of 5,900 and $7,900 \mathrm{ft}$, where the inversion base is most frequently found (Giambelluca and Nullet, 


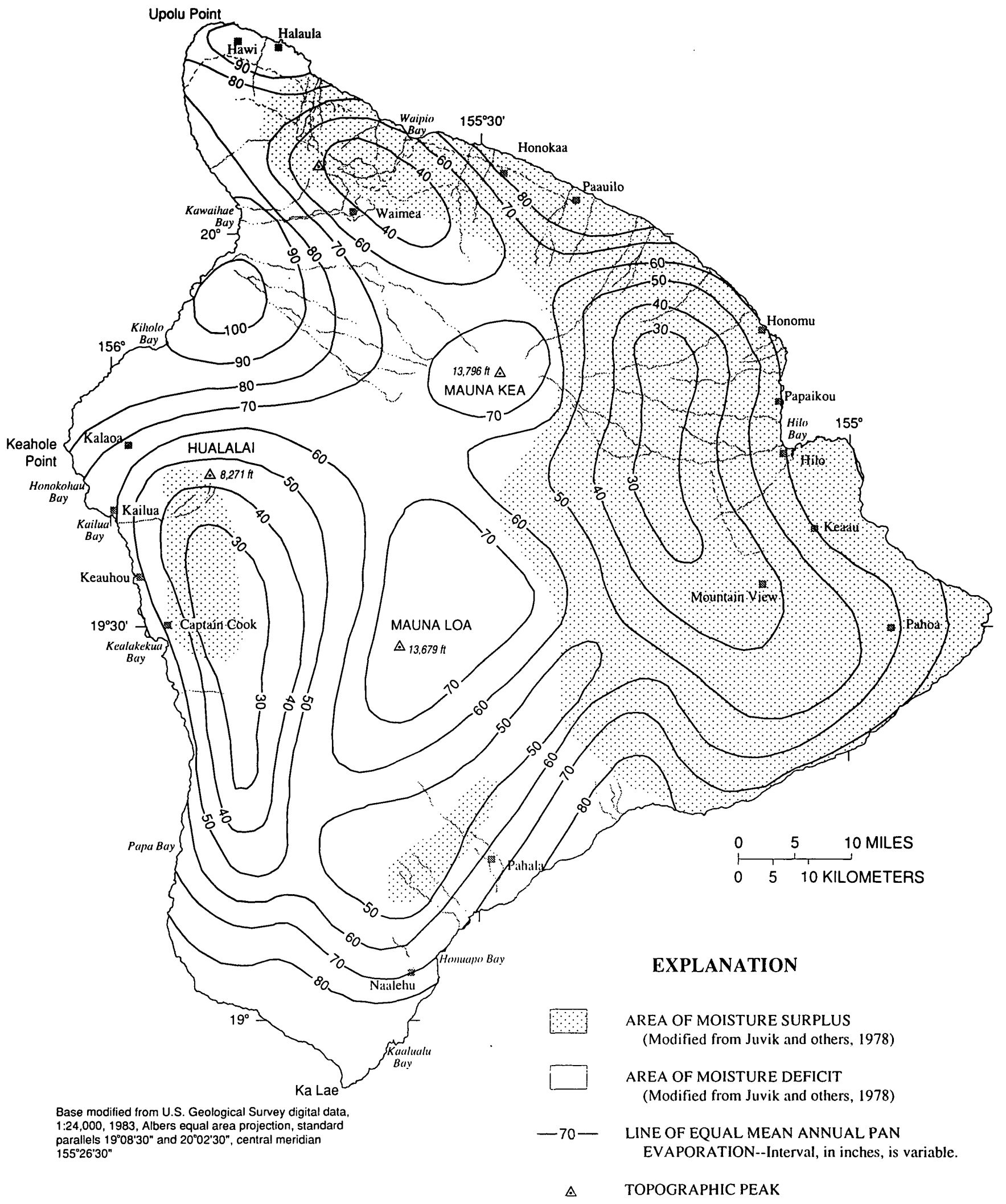

Figure 10. Mean annual pan evaporation, island of Hawaii (modified from Ekern and Chang, 1985). 
1991), the evaporation rate increases because of positive heat advection (Giambelluca and Nullet, 1992). The magnitude of the evaporation-rate gradient is greatest in the zone from 5,900 to 7,900 ft (Bean and others, 1994). Above an altitude of $7,900 \mathrm{ft}$, air above the inversion is dry and the evaporation rate continues to increase with altitude (Bean and others, 1994).

\section{Ground-Water Recharge}

Juvik and others (1978) mapped areas of annual moisture surplus and deficit on the island of Hawaii. In the Kona area, the coastal areas and upper slopes of Mauna Loa were mapped as areas of moisture deficit. A moisture-surplus area was mapped on the lower slopes of Mauna Loa and Hualalai (fig. 10).

Ground-water recharge in the Keauhou, Kealakekua, Kaapuna, and Manuka aquifer systems (fig. 11) (Mink and Lau, 1993) was estimated to be $87,86,115$, and $96 \mathrm{Mgal} / \mathrm{d}$, respectively (State of Hawaii, 1990), representing about 25 percent of the rainfall to these areas. The area formed by the Keauhou, Kealakekua, Kaapuna, and Manuka aquifer systems (Mink and Lau, 1993) is about the same as the recharge area used in this study. In an area just north of the Kona area, Kanehiro and Peterson (1977) estimated that about 15 percent of the annual rainfall becomes ground-water recharge. Mink and others (1993) suggested that the permeable volcanic rocks, even when covered by dense vegetation, can have high infiltration capacities, and that as much as two-thirds of precipitation becomes recharge.

For this study, the spatial distribution of average annual precipitation estimated by Giambelluca and others (1986) (see fig. 8) was used as input to the water budget. Areas between adjacent lines of equal rainfall (fig. 8) were assigned the average of the rainfall values for the lines. The fog drip contribution to the water budget was estimated using equation 3 , figure 8 , and landsurface altitudes from a USGS topographic map (U.S. Geological Survey, 1975). Areas between adjacent topographic contours were assigned an altitude equal to the average of the altitudes for the two contours. Fog drip was assumed to be zero below the 2,400 -ft contour. Average annual runoff was estimated to be 5 percent of average annual precipitation. Average annual evapotranspiration was estimated to be equal to average annual pan evaporation (fig. 10), except in wet, forested areas (Jacobi, 1989). In the wet, forested areas, average annual evapotranspiration was estimated to be 130 percent of pan evaporation (see for example Giambelluca, 1983).

Equation 1 predicts zero recharge for areas where evapotranspiration plus runoff exceeds precipitation plus fog drip. The annual water budget, however, fails to recognize recharge associated with individual periods of rainfall. Because the surface rocks and soils in the Kona area have high infiltration capacities, it is not realistic to assume zero recharge even in areas with high evapotranspiration rates. Individual periods of rainfall, especially larger storms, are likely to lead to some ground-water recharge. Thus, for this study, a conservative lower bound, equal to 15 percent of average annual precipitation, was placed on the recharge estimate. That is, in areas where equation 1 predicted recharge as being less than 15 percent of precipitation, recharge was set equal to 15 percent of precipitation. The 0.15 rechargeto-rainfall ratio represents the most conservative published recharge-to-rainfall ratio for the Kona area (Kanehiro and Peterson, 1977; State of Hawaii, 1990; Mink and others, 1993).

Using equation 1 and a minimum 0.15 recharge-torainfall ratio, average annual recharge in the Kona study area was estimated to be $357.5 \mathrm{Mgal} / \mathrm{d}$. Of this total, it is estimated that fog drip accounts for about $63 \mathrm{Mgal} / \mathrm{d}$. The water-budget results suggest that fog drip does not contribute significantly to recharge above an altitude of $8,000 \mathrm{ft}$. Spatially, average annual recharge ranges from less then 5 in. near the summit of Mauna Loa and near the coast at Keahole Point and $\mathrm{Ka} \mathrm{Lae}$, to as much as 53 in. at an altitude of about 2,700 ft near Kiilae Stream (fig. 12).

Although the average annual recharge estimated for this study is within 7 percent of the previously estimated value of $384 \mathrm{Mgal} / \mathrm{d}$ (State of Hawaii, 1990), there is an unquantified uncertainty associated with the estimate obtained for this study. The uncertainty is associated with the data (spatial distributions of precipitation, fog drip, and evapotranspiration) as well as the annual water-budget model. Nevertheless, rigorous recharge and associated uncertainty estimates for the Kona area cannot be made until more data become available and the understanding of the physical processes affecting recharge is improved. 


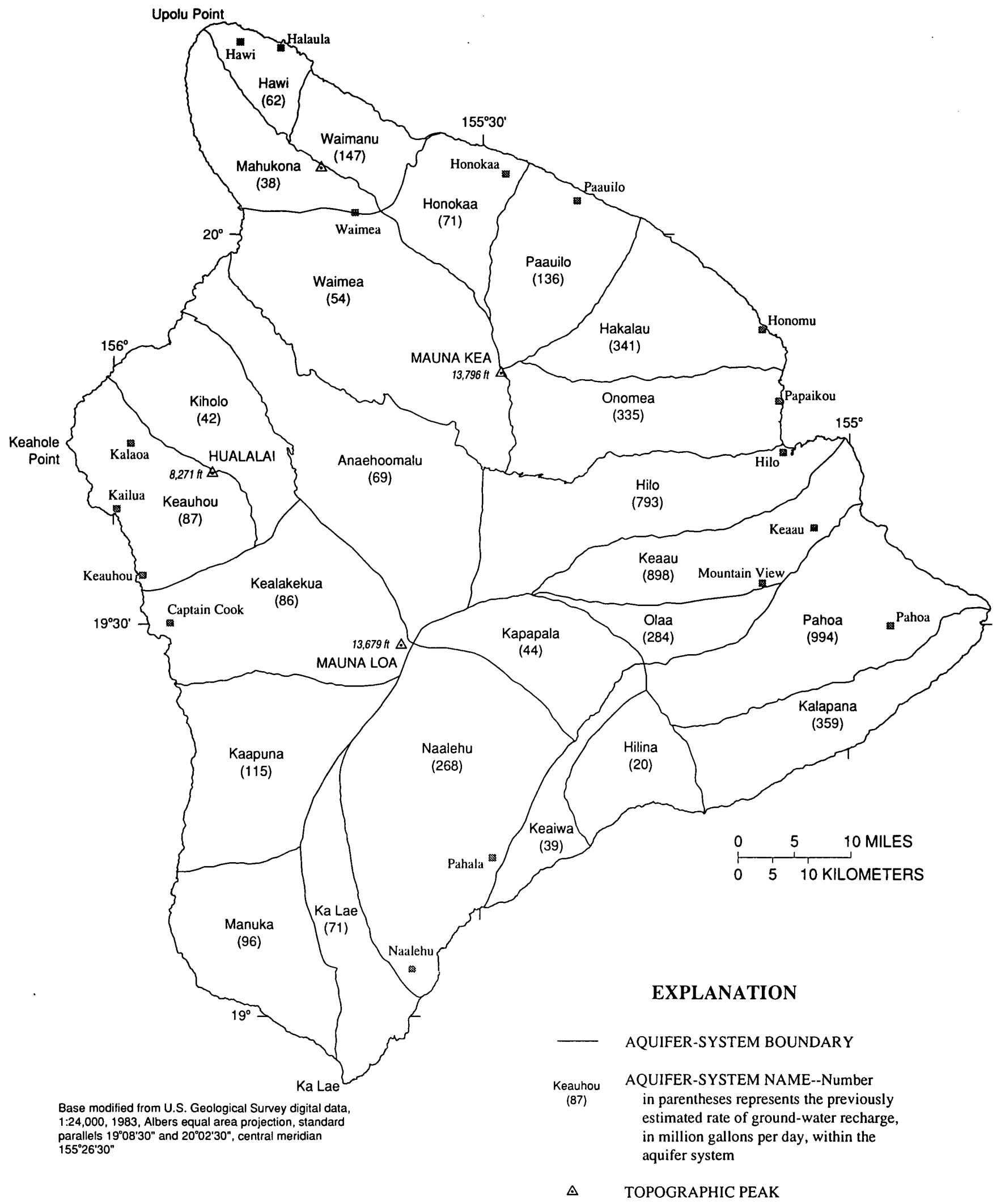

Figure 11. Aquifer-system boundaries (Mink and Lau, 1993) and previously estimated ground-water recharge (State of Hawaii, 1990), island of Hawaii. 


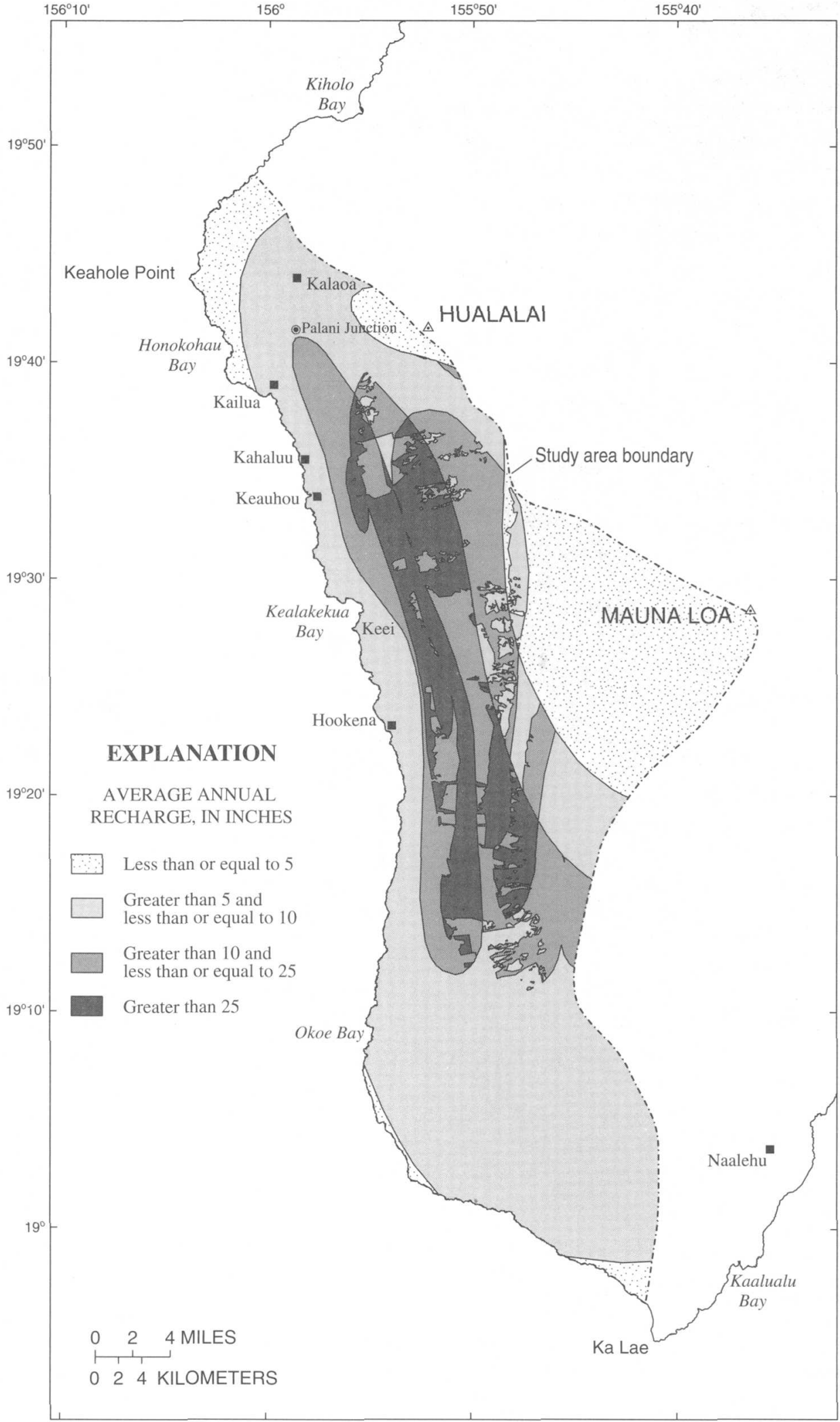

Base modified from U.S. Geological Survey digital data, 1:24,000, 1983, Albers equal area projection, standard parallels $19^{\circ} 08^{\prime} 30^{\prime \prime}$ and $20^{\circ} 02^{\prime} 30^{\prime \prime}$, central meridian $155^{\circ} 26^{\prime} 30^{\prime \prime}$

Figure 12. Average annual ground-water recharge within the Kona study area, island of Hawaii. 


\section{GROUND-WATER DATA}

Because most of the ground-water development in the Kona study area has taken place north of Honaunau, data related to ground-water levels and ground-water quality are available mainly to the north of Honaunau (see fig. 2). Although high water levels (greater than 40 $\mathrm{ft}$ above sea level) have not been measured in wells south of Honaunau, very few wells have been drilled in inland areas above an altitude of $1,000 \mathrm{ft}$ in the southern part of the study area.

\section{Ground-Water Withdrawals}

Most of the ground water withdrawn from the Kona area is from a coastal body of freshwater or brackish water floating on denser saltwater, and a smaller amount is withdrawn from the inland area where high water levels exist. The total reported annual mean pumpage for the Kona area during 1997 was 11.1 $\mathrm{Mgal} / \mathrm{d}$ (computed from unpub. data from Hawaii Commission on Water Resource Management). An additional estimated $2.9 \mathrm{Mgal} / \mathrm{d}$ of saline water was withdrawn from the Kona area. Of the reported 11.1 $\mathrm{Mgal} / \mathrm{d}$ withdrawn in $1997,9.8 \mathrm{Mgal} / \mathrm{d}$ was withdrawn by the County of Hawaii Department of Water Supply (DWS).

The DWS maintains five wells near Kahaluu (3557-01 to -05), three wells near Keei (2653-01, 275301 to -02), and one well near Holualoa (3657-01) that are used to withdraw water from the coastal part of the ground-water system, seaward of the area where high water levels exist. Combined withdrawals from these nine DWS wells have increased with time (fig. 13) and averaged 7.7 Mgal/d in 1997. The Kahaluu wells (355701 to -05) were drilled between 1959 and 1976, the Keei wells (2653-01, 2753-01 to -02) were drilled between 1958 and 1978, and the Holualoa well (3657-01) was drilled in 1983.

Beginning in 1994, the DWS began withdrawing ground water from the area with high water levels from Kalaoa well 4358-01. By 1997, the DWS was using three additional wells (Keei well D, 2753-03; Queen Liliuokalani Trust well, 4057-01; and Halekii well, 3155-02) to withdraw ground water from the high water-level area. During 1997, the average combined withdrawal from the four DWS wells in the high waterlevel area was 2.1 Mgal/d. During December 1997, combined withdrawal from these four DWS wells reached 2.5 Mgal/d (fig. 14).

A number of privately owned wells are used to withdraw water from the coastal part of the groundwater system in the Kona area, where water levels are generally less than $10 \mathrm{ft}$ above sea level. Reported combined withdrawal from two agricultural irrigation wells (0952-01 and 0953-01) near Okoe Bay has averaged about $0.5 \mathrm{Mgal} / \mathrm{d}$ from 1989-97 (fig. 13). Reported combined withdrawal from three privately owned golfcourse irrigation wells (3357-04, 3457-01, and 345703 ) near Keauhou has usually been between 0.5 and 1.5 $\mathrm{Mgal} / \mathrm{d}$ since 1996 . Five privately owned wells (Huehue Ranch wells 4459-01 to -02, 4558-01 to -02, and 455901) near Kalaoa are used for both domestic and irrigation purposes. Combined withdrawals from the Huehue Ranch wells have usually been between 0.2 and 0.5 Mgal/d since 1991. During the 1990's, the estimated withdrawal of saline water for aquaculture from Keahole wells 4363-01 to -10 has been about 2.9 Mgal/d (Neal Fujii, Hawaii Commission on Water Resource Management, oral commun., 1998). Total unreported withdrawals from other privately owned wells that are used to withdraw ground water from the Kona area are probably small.

\section{Ground-Water Levels}

Ground-water flow rates and directions are difficult to measure directly, and are usually inferred from water levels. Changes in ground-water levels also are an indicator of changes in recharge or withdrawals from the ground-water system. In the Kona area, measured ground-water levels range from near sea level to 1,280 $\mathrm{ft}$ above sea level.

\section{Spatial Distribution}

Because existing data from wells are limited, a reliable contour map of water levels for the entire Kona study area cannot be drawn. Measured water levels are available primarily at wells within about $5 \mathrm{mi}$ of the coast (fig. 15, table 2). The general distribution of water levels in the Kona area (fig. 15) was obtained from measurements taken from 1991-93. The 1991-93 time period was selected for the study area because (1) ground-water withdrawals were relatively steady during this period, (2) the best available spatial distribution of water-level measurements are from this period, and 

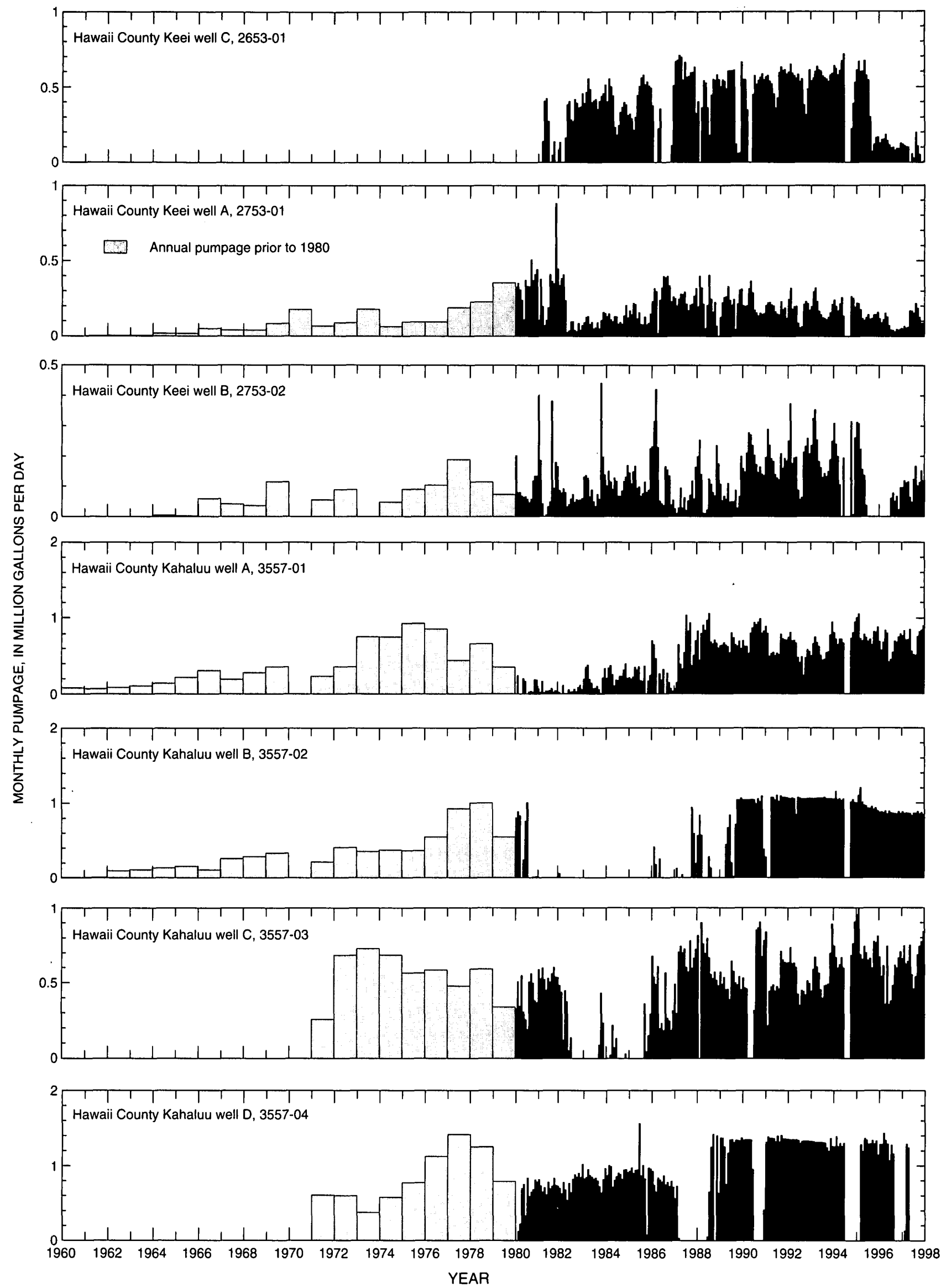

Figure 13. Monthly pumpage from selected wells located seaward of the high water-level area, Kona, island of Hawaii (data after 1980 from Commission on Water Resource Management, 1998, unpub.). Data missing from July 1994 to September 1994 for Hawaii County wells. 

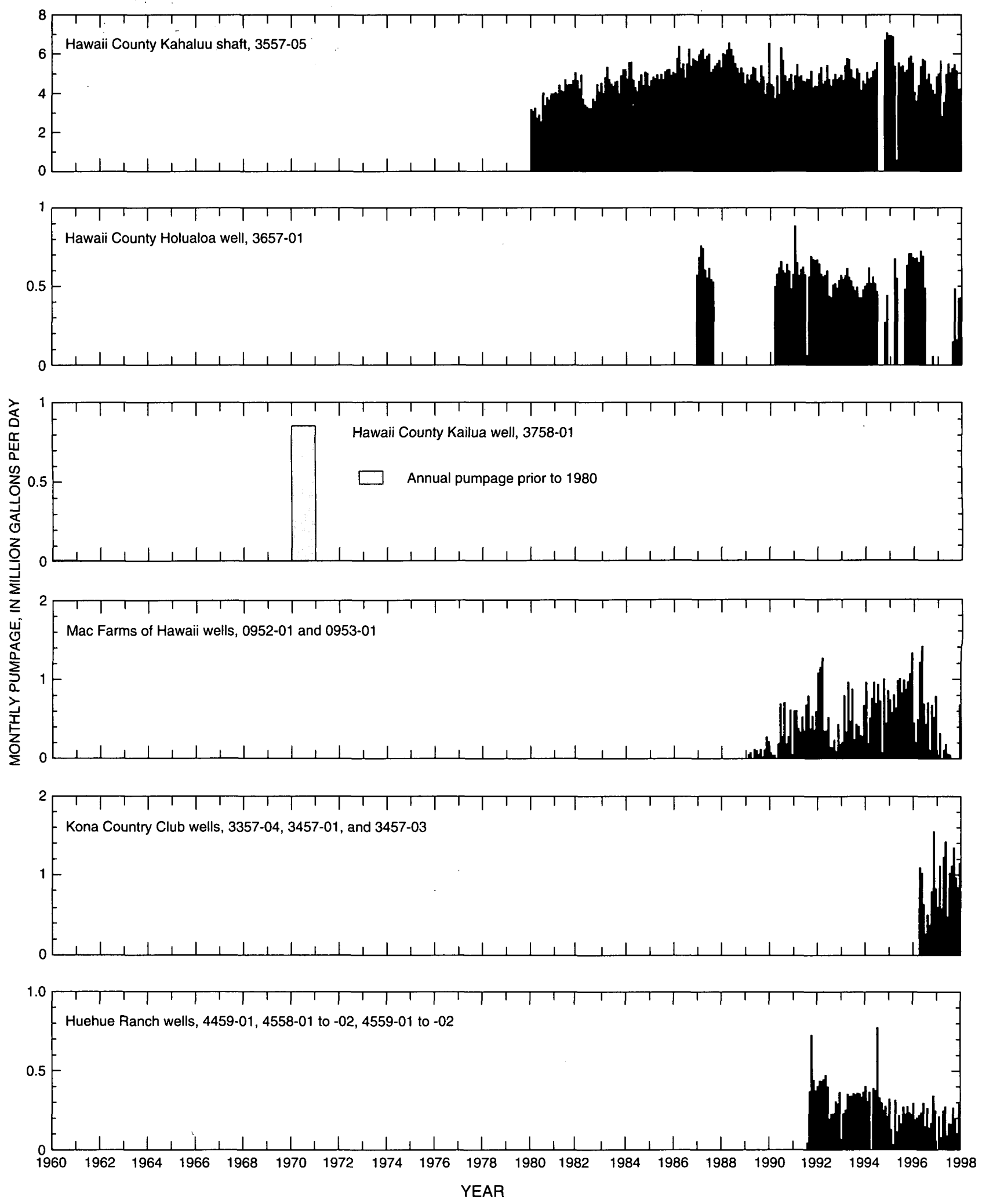

Figure 13. Monthly pumpage from selected wells located seaward of the high water-level area, Kona, island of Hawaii (data after 1980 from Commission on Water Resource Management, 1998, unpub.). Data missing from July 1994 to September 1994 for Hawaii County wells--Continued. 

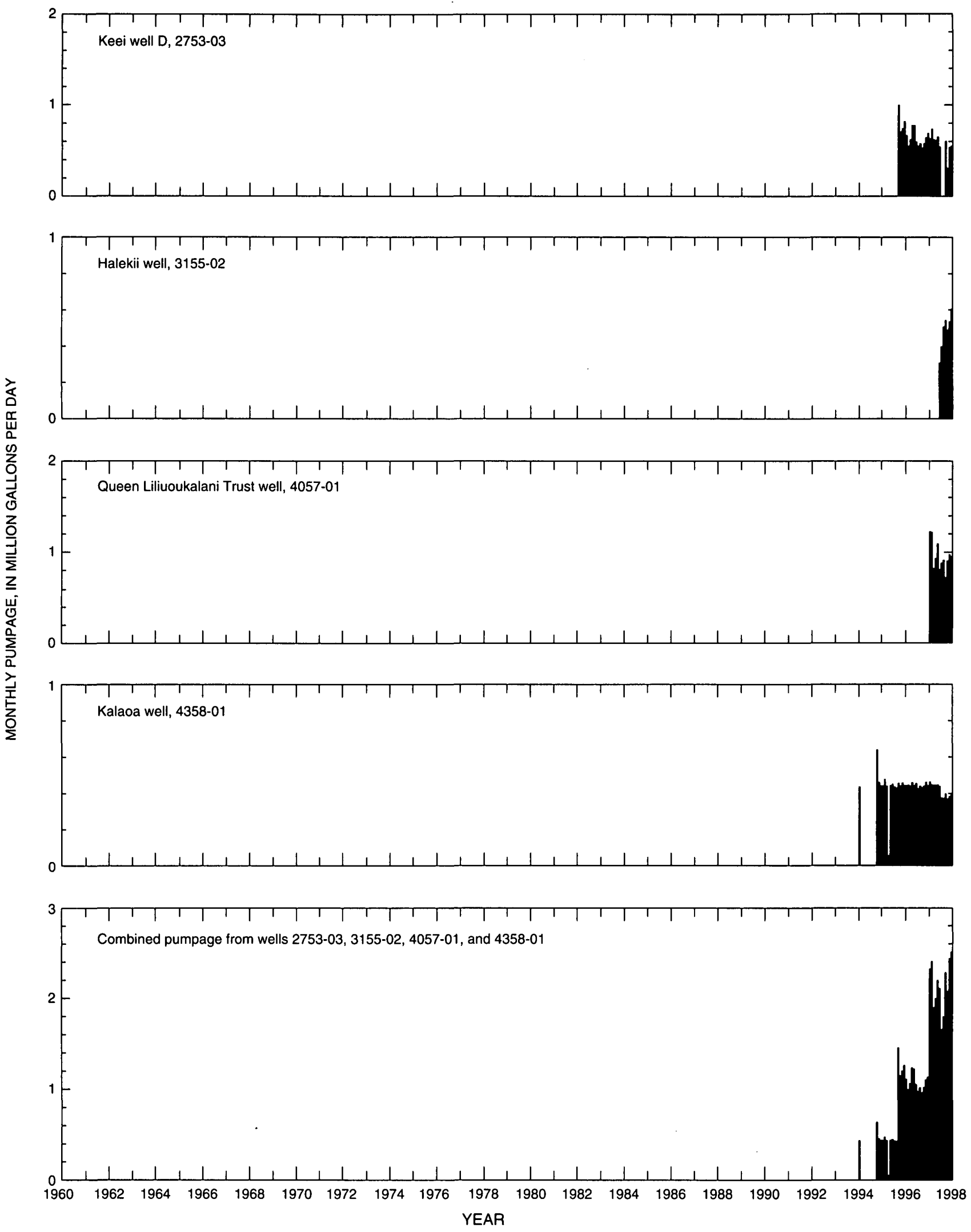

Figure 14. Monthly pumpage from selected Hawaii County wells, high water-level area, Kona, island of Hawaii (data from Commission on Water Resource Management, 1998, unpub.). 


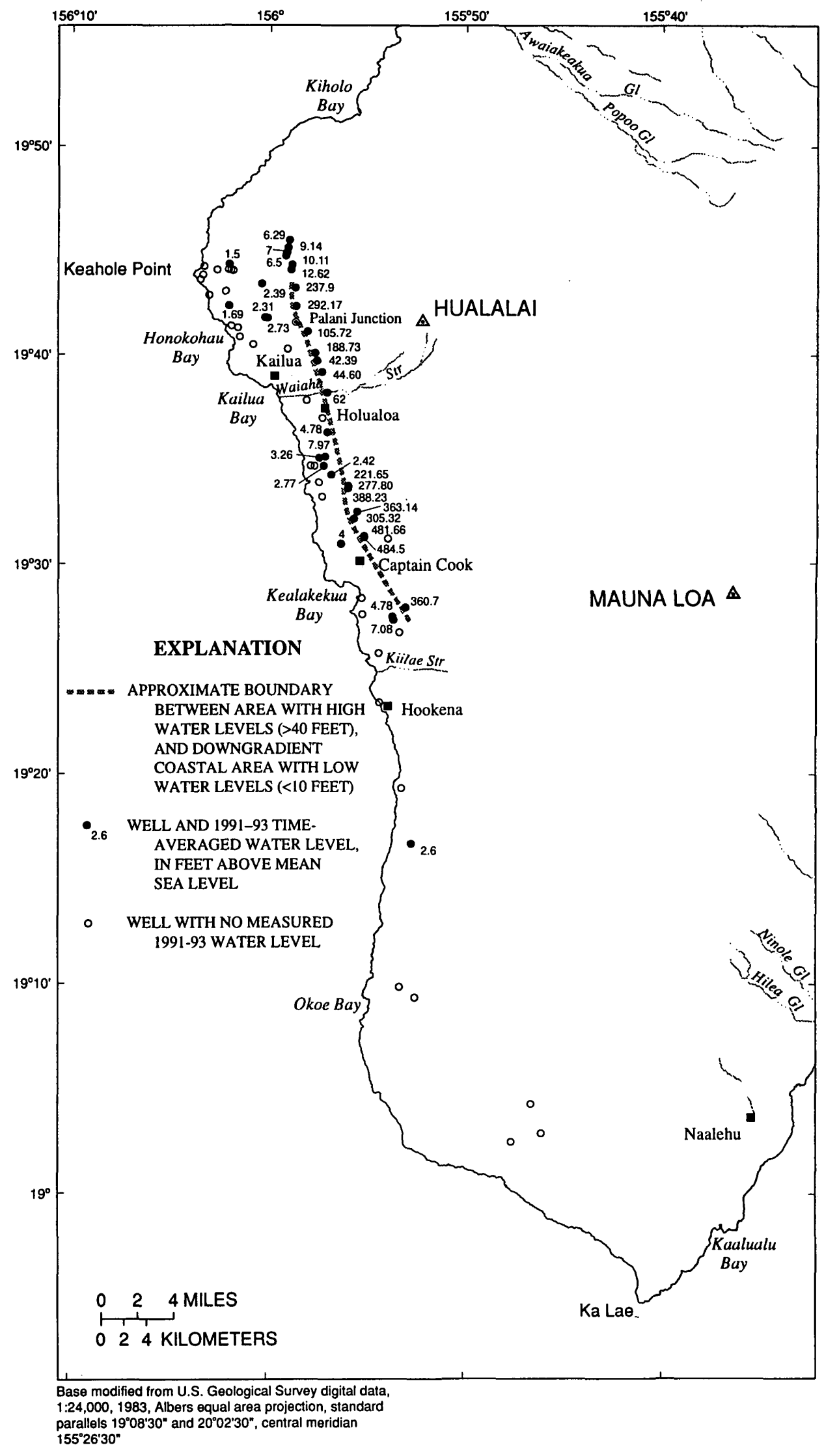

Figure 15. Time-averaged measured water levels for 1991-93 in the Kona area, island of Hawaii. 
Table 2. Initial available water level from selected wells in the Kona area, island of Hawaii

[CWRM, Commission on Water Resource Management; USGS, U.S. Geological Survey; n.a., not applicable; --, measuring device not specified]

\begin{tabular}{|c|c|c|c|c|}
\hline Well number & $\begin{array}{c}\text { Water level } \\
\text { (feet) }\end{array}$ & Date & Measuring device & Source of data \\
\hline $0246-01$ & 9.5 & $12 / 1 / 83$ & steel tape & CWRM well file \\
\hline $0247-01$ & 7.85 & n.a. & air line & CWRM well file \\
\hline 0953-01 & 3.8 & $9 / 80$ & -- & CWRM well completion report \\
\hline $1652-01$ & 2.6 & $4 / 8 / 93$ & -- & CWRM well completion report \\
\hline $2653-01$ & 4.25 & $8 / 7 / 78$ & air line & CWRM well file \\
\hline 2753-01 & 2.75 & $12 / 17 / 58$ & air line & USGS well file \\
\hline $2753-02$ & 2.30 & $4 / 29 / 63$ & wire and milliameter & USGS well file \\
\hline $2753-03$ & 360.7 & $11 / 20 / 91$ & -- & CWRM well completion report \\
\hline $3056-01$ & 4 & $2 / 3 / 93$ & -- & CWRM well completion report \\
\hline $3153-01$ & 1,280 & $11 / 19 / 96$ & -- & CWRM well completion report \\
\hline $3155-01$ & 481.89 & $8 / 4 / 93$ & electronic meter & USGS well file \\
\hline $3155-02$ & 484.5 & $12 / 92$ & -. & CWRM well completion report \\
\hline $3255-01$ & 364.50 & $9 / 6 / 91$ & electronic meter & CWRM well file \\
\hline $3255-02$ & 306.46 & $8 / 3 / 93$ & -- & CWRM well completion report \\
\hline $3355-01$ & 278.09 & $8 / 2 / 90$ & -- & CWRM well completion report \\
\hline $3355-02$ & 386 & $7 / 13 / 92$ & -- & CWRM well completion report \\
\hline $3355-03$ & 228 & $6 / 17 / 93$ & -- & CWRM well completion report \\
\hline $3357-04$ & 2 & $10 / 12 / 90$ & -- & CWRM well completion report \\
\hline $3456-01$ & 3.5 & 1989 & -- & CWRM well completion report \\
\hline $3457-02$ & 2.85 & $9 / 5 / 85$ & -- & USGS well file \\
\hline $3557-01$ & 4.04 & $5 / 21 / 59$ & -- & USGS well file \\
\hline $3557-02$ & 3.2 & $10 / 7 / 59$ & -- & USGS well file \\
\hline $3557-03$ & 2.46 & $2 / 5 / 75$ & air line & USGS well file \\
\hline $3557-04$ & 5.27 & $3 / 20 / 73$ & air line & USGS well file \\
\hline $3557-05$ & 3.39 & $11 / 4 / 93$ & -. & USGS well file \\
\hline $3657-01$ & 5.64 & $12 / 1 / 83$ & steel tape & State of Hawaii, 1984 \\
\hline $3657-02$ & 4.28 & $7 / 16 / 90$ & -- & CWRM well completion report \\
\hline $3758-01$ & 1.58 & $6 / 14 / 47$ & -- & USGS well file \\
\hline $3857-01$ & 62 & n.a. & -- & State of Hawaii, 1995 \\
\hline $3957-01$ & 42.00 & $8 / 4 / 92$ & electronic meter & CWRM well file \\
\hline $3957-02$ & 40 & $7 / 15 / 91$ & electronic meter & USGS well file \\
\hline $4057-01$ & 188.73 & $11 / 15 / 93$ & electronic meter & CWRM well file \\
\hline $4059-01$ & 1.44 & $9 / 17 / 58$ & -- & USGS well file \\
\hline $4060-01$ & 2 & $7 / 7 / 95$ & -- & CWRM well completion report \\
\hline $4061-01$ & 0.87 & $4 / 3 / 96$ & electronic meter & USGS well file \\
\hline $4158-02$ & 109.51 & $3 / 18 / 91$ & -- & CWRM well completion report \\
\hline $4160-01$ & 2.5 & $7 / 15 / 85$ & -- & CWRM well completion report \\
\hline $4160-02$ & 1.4 & $11 / 25 / 85$ & -- & CWRM well completion report \\
\hline 4161-01 & 1.14 & $4 / 3 / 96$ & electronic meter & USGS well file \\
\hline $4161-02$ & 1.08 & $4 / 3 / 96$ & electronic meter & USGS well file \\
\hline $4258-03$ & 292.44 & $10 / 7 / 93$ & electronic meter & CWRM well file \\
\hline $4262-01$ & 1.50 & $1 / 28 / 93$ & electronic meter & CWRM well file \\
\hline $4358-01$ & 255 & $9 / 18 / 90$ & -- & CWRM well completion report \\
\hline $4360-01$ & 3.2 & $10 / 29 / 68$ & electric sounding probe & State of Hawaii, 1968 \\
\hline $4458-01$ & 10.4 & $5 / 30 / 90$ & logger & Water Resource Associates, 1991 \\
\hline $4458-02$ & 14.94 & $3 / 11 / 91$ & logger & CWRM well file \\
\hline $4459-01$ & 6.5 & 1991 & -- & CWRM well completion report \\
\hline $4459-02$ & 7 & $5 / 25 / 92$ & -- & CWRM well completion report \\
\hline $4462-02$ & 1.5 & $12 / 14 / 92$ & -- & CWRM well completion report \\
\hline 4558-01 & 9.91 & 1991 & -- & CWRM well completion report \\
\hline $4558-02$ & 22.5 & $9 / 25 / 92$ & -- & CWRM well completion report \\
\hline $4559-01$ & 8 & $2 / 85$ & -- & CWRM well completion report \\
\hline
\end{tabular}


(3) there were no significant water-level trends during this period (particularly outside of the high water-level area). For each well, the time-averaged water level shown in figure 15 was computed by determining the area under the water-level hydrograph for the well from 1991-93 (see figs. 16-18), and dividing the area by the length of the time period ( 2 years). In some cases, only one measurement was available during 1991-93, and in one case (well 4458-02), eight measurements were available.

Within 2 mi from the coast, measured water levels are less than $10 \mathrm{ft}$ above sea level. However, water levels less than $10 \mathrm{ft}$ above sea level have been measured farther inland in some places. In the area north of Kalaoa, for example, wells with water levels less than $10 \mathrm{ft}$ above sea level have been drilled as far as $4.5 \mathrm{mi}$ inland. Where water levels less than $10 \mathrm{ft}$ above sea level exist, the magnitude of the horizontal head gradient is generally on the order of a foot per mile. Measured water levels increase in an inland direction.

Wells with measured water levels greater than 40 $\mathrm{ft}$ above sea level have been drilled between Kalaoa and Honaunau, at distances ranging from 2 to $4.5 \mathrm{mi}$ inland. In this area, measured water levels are generally between about 40 and $500 \mathrm{ft}$ above sea level. Between Palani Junction and Holualoa, measured water levels are between 40 and $200 \mathrm{ft}$ above sea level. North of Palani Junction and south of Holualoa, measured water levels are between 200 and $500 \mathrm{ft}$ above sea level with one exception. As of May 1998, only one well (315301 ) had a measured water level greater than $500 \mathrm{ft}$. On November 11, 1996, the water level measured in well 3153-01, located at a ground-surface altitude of 2,530 $\mathrm{ft}$, was reported to be $1,280 \mathrm{ft}$ above sea level. Of the wells drilled prior to May 1998 in the high water-level area, Kainaliu well $3255-02$ is nearest to the coast, at a distance of about 2 mi inland.

Data are not sufficient to fully describe the spatial pattern of water levels in the compartmentalized part of the aquifer where high water levels exist. Water levels can vary significantly over relatively short distances. For example, measured water levels from wells 335502 and 3355-03, which are located within about $800 \mathrm{ft}$ of each other, differ by about $160 \mathrm{ft}$.

The transition between the high water-level area and the downgradient coastal area with water levels less than $10 \mathrm{ft}$ above sea level can occur over a short distance. For example, Keei well 2753-03, which has a measured water level of $360.7 \mathrm{ft}$ above sea level, is less than 0.9 mi inland from Keei well 2753-01, which has measured water levels less than $10 \mathrm{ft}$ above sea level. Near these wells, the magnitude of the horizontal head gradient is greater than $380 \mathrm{ft} / \mathrm{mi}$.

Water levels measured in some wells may not be an accurate indicator of the position of the water table because of vertical head gradients. Water levels measured in State Hualalai exploratory well 4258-03 increased by about $100 \mathrm{ft}$ after the well was deepened by about $100 \mathrm{ft}$, which indicates that the magnitude of the average vertical head gradient over the bottom 100 $\mathrm{ft}$ of the well is about $1 \mathrm{ft} / \mathrm{ft}$. Where vertical head gradients exist, water levels measured in wells represent a vertically averaged water level for the part of the aquifer penetrated by the well.

In the inland area north of Kalaoa, wells with water levels ranging from 6 to $23 \mathrm{ft}$ above sea level have been drilled. These wells are located within a transition area between the coastal part of the system, where water levels are less than $10 \mathrm{ft}$ above sea level, and the high water-level area.

\section{Temporal Variation}

At many wells, only single water-level measurements are available, and the reference datums used for some of these wells are not accurately known. Reliable long-term water-level records do not exist for most wells in the Kona area. Five wells (2753-01, 2753-02, 3557-01, 3557-03, and 3758-01) in the Kona area have measured water levels in at least 10 different years from 1947 to 1995 (fig. 16). Water levels in these five pumped wells were measured using air-line devices with limited accuracy. Measured water levels from wells 2753-01, 2753-02, 3557-01, and 3557-03 show relatively large variations from one measurement to the next. These large variations could be attributed partly to pumping, but are most likely related to the inaccuracy of the pressure measurements made with an air-line device. The hydrograph for well 2753-02 (fig. 16) indicates an increase in water levels from about $3 \mathrm{ft}$ in the 1970 's to about $7 \mathrm{ft}$ in the 1990's. This upward trend probably does not accurately reflect water-level conditions in the aquifer (both withdrawals and chloride concentrations of water from pumped wells have increased from the 1970's to the 1990's).

In 1991, CWRM began a program of water-level measurements in the Kona area. Measured water levels 

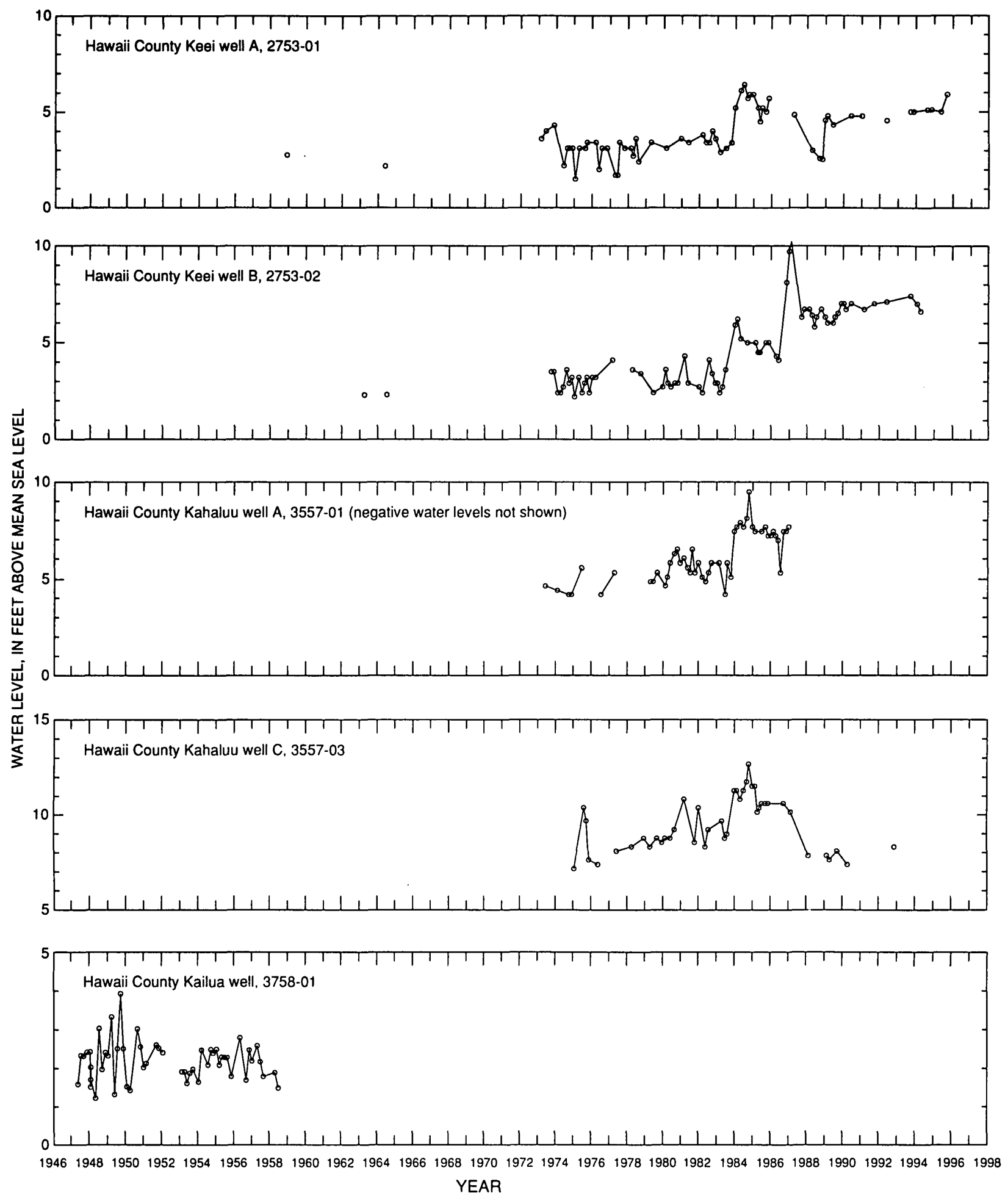

Figure 16. Water levels estimated from air-line pressure measurements in selected wells located seaward of the high water-level area, Kona, island of Hawaii. Only measurements made with the pump off are shown (data points not connected for data gaps exceeding one year). 

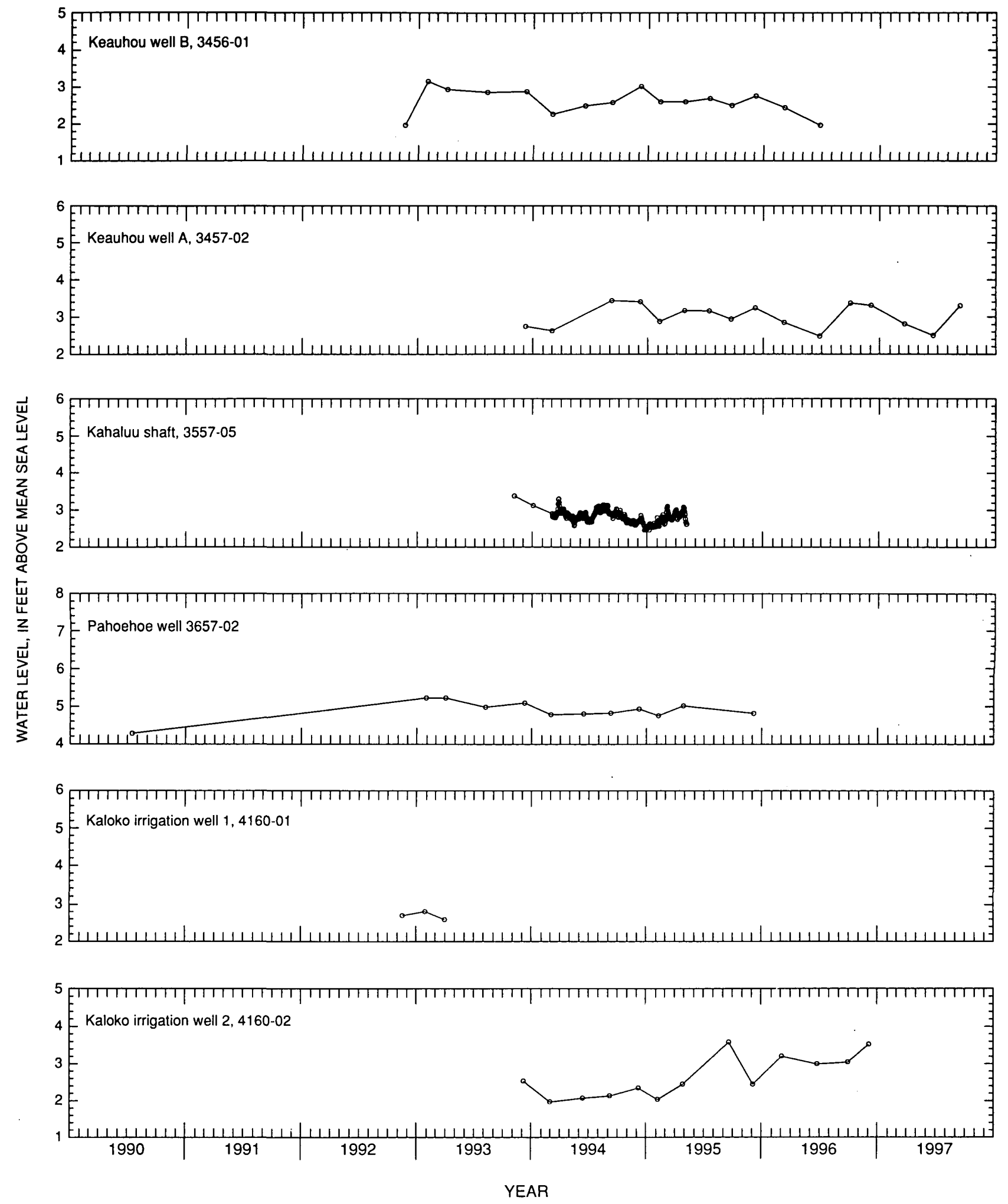

Figure 17. Measured water levels in selected wells located seaward of the high water-level area, Kona, island of Hawaii (data for all wells except 3557-05 from Commission on Water Resource Management, 1997, unpub.). 

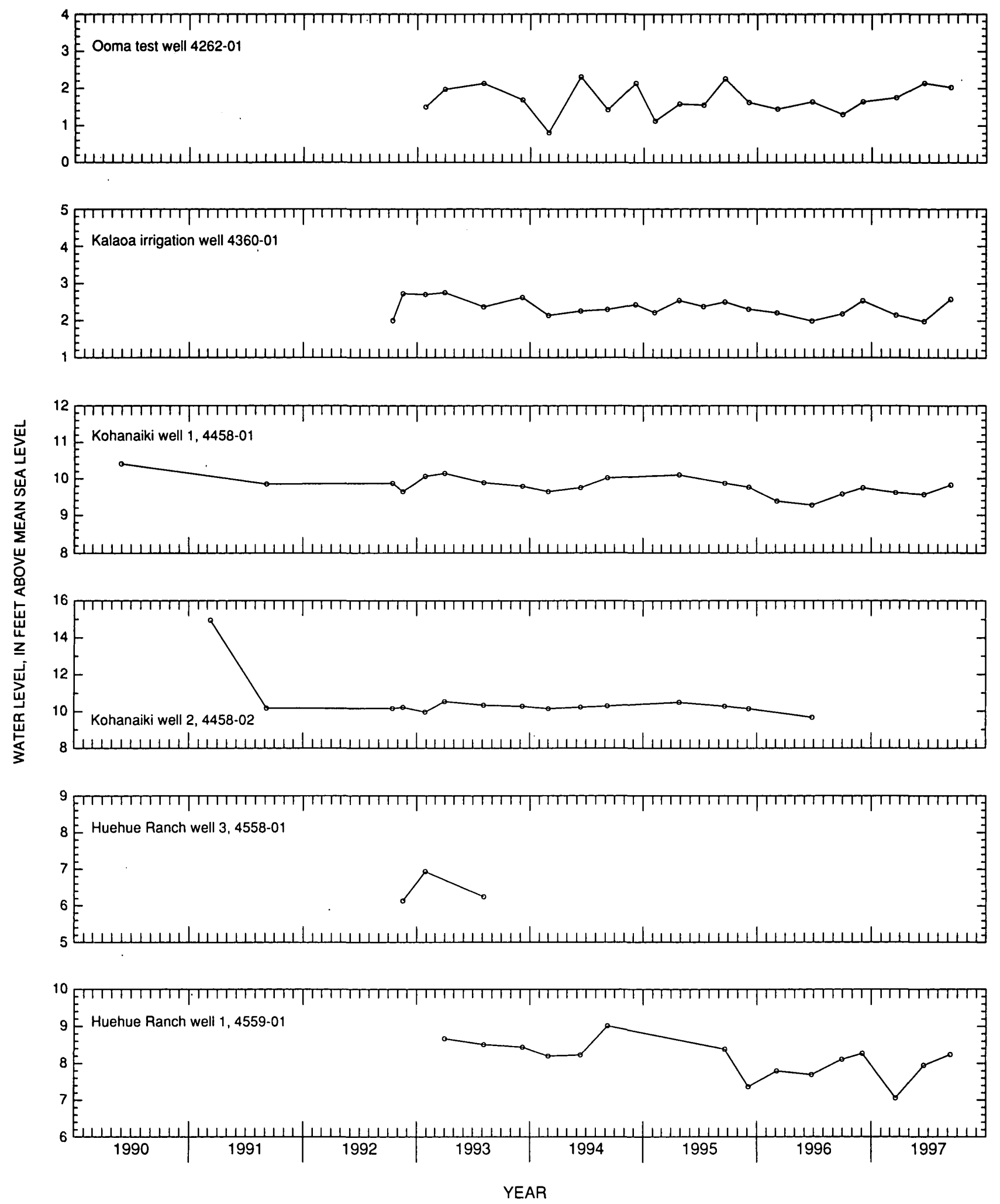

Figure 17. Measured water levels in selected wells located seaward of the high water-level area, Kona, island of Hawaii (data for all wells except 3557-05 from Commission on Water Resource Management, 1997, unpub.)--Continued. 

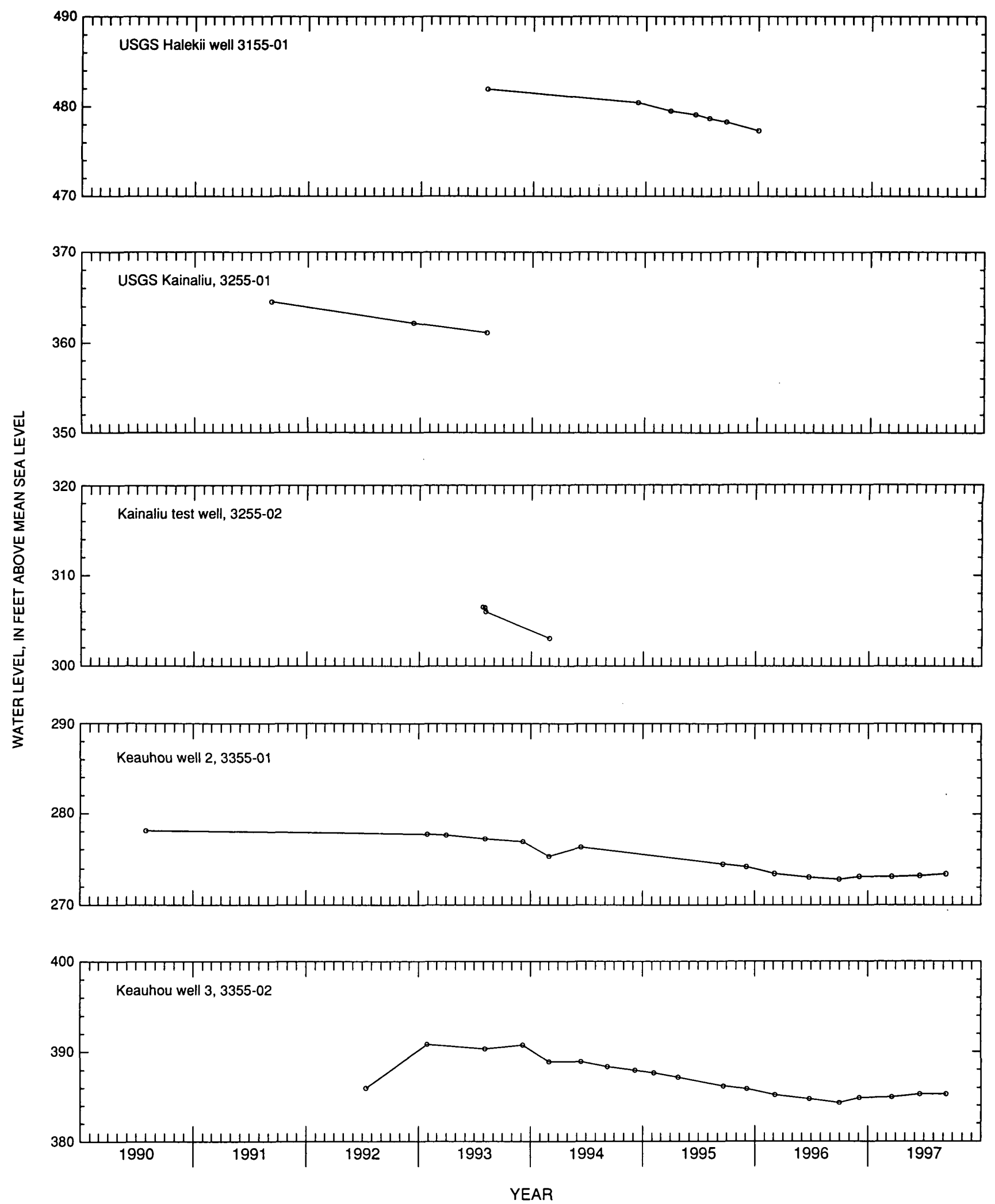

Figure 18. Measured water levels in selected wells, high water-level area, Kona, island of Hawaii (data from Commission on Water Resource Management, 1997, unpub.). 

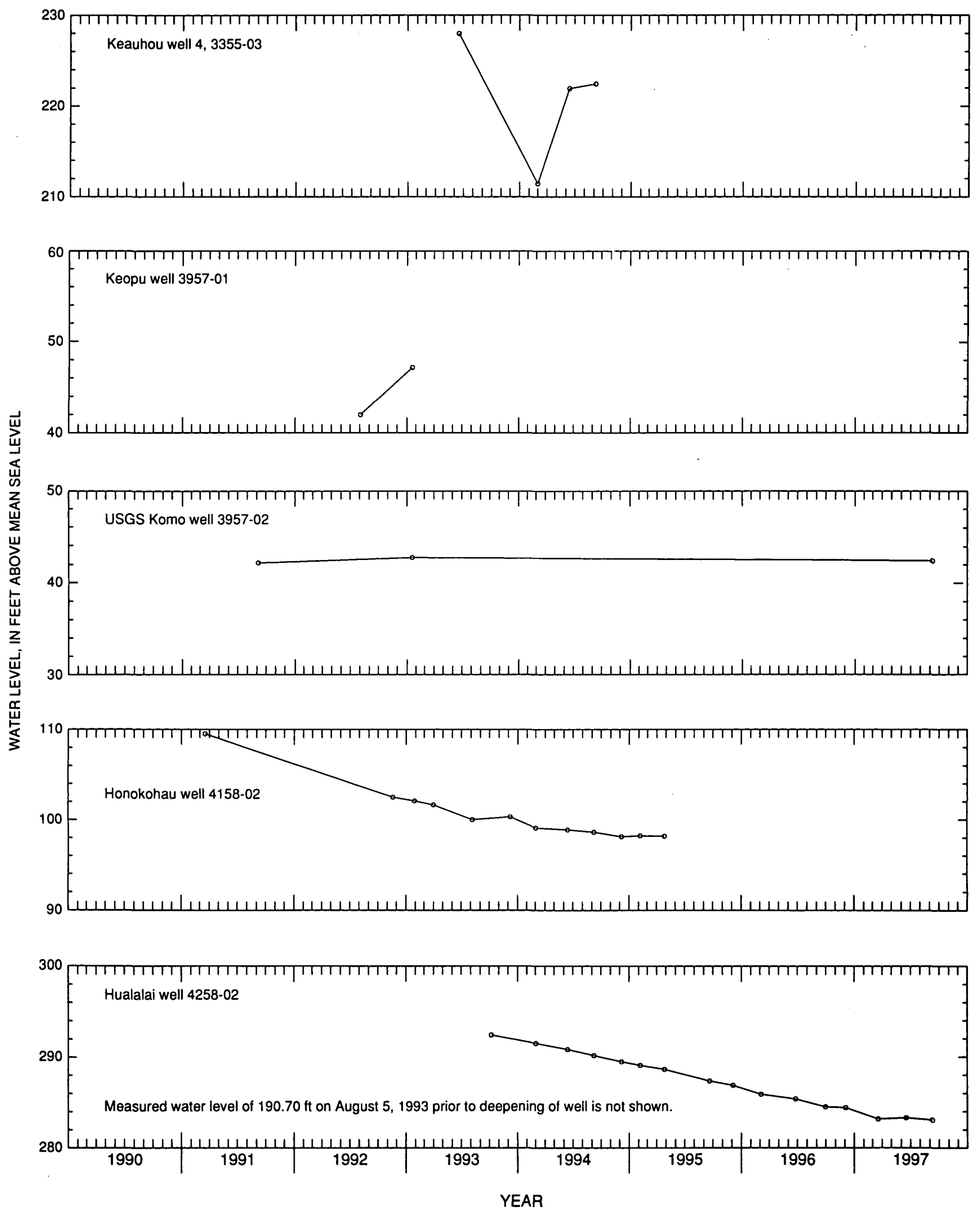

Figure 18. Measured water levels in selected wells, high water-level area, Kona, island of Hawaii (data from Commission on Water Resource Management, 1997, unpub.)--Continued. 
for wells with water levels less than $40 \mathrm{ft}$ above sea level (fig. 17) do not show any consistent upward or downward trend during 1991-97. Water levels in well 4160-02 indicate a slight upward trend from 1993 to 1996 (fig. 17). However, water levels in well 4559-01 (fig. 17) indicate a slight downward trend from 1993 to 1996. This same downward water-level trend exists in data from several wells that are located in the high water-level area (fig. 18). Although measured water levels from some wells located in the high water-level area have a downward trend during the 1990's, the magnitude of the water-level change from a given well (with the exception of well 4158-02) is generally less than 5 percent of the average water level from that well. Note also that some of the initial water-level measurements (fig. 18, table 2) from the CWRM well-completion reports may be unreliable because accurate measuring devices or reference-mark altitudes may not have been available.

\section{Chloride Concentration}

Chloride concentration is generally used as an indicator of saltwater intrusion into the ground-water system. In general, chloride concentrations are expected to increase with depth in the aquifer and proximity to the ocean. Exceptions to this generalization, however, can exist because of local-scale heterogeneities in the aquifer. The chloride concentration of water pumped from a well in close proximity to the ocean generally increases with pumping rate.

Several shallow monitoring wells (less than $50 \mathrm{ft}$ into the aquifer) were drilled near Keahole Point to determine the salinity of ground water in the aquifer as a function of depth (Nance, 1991). Salinity profiles from these wells indicate an increase of salinity with depth (fig. 19). At a given depth, the salinity in well $\mathrm{W}-1$, located about 5,200 ft inland, is less than the salinity in well W-2, which is located closer to the coast (fig. 3 ). Note that chloride concentration is directly related to salinity.

Chloride concentrations of water samples from wells drilled in the high water-level area are less than 20 $\mathrm{mg} / \mathrm{L}$ (table 3). Chloride concentrations of water samples from wells drilled seaward of the high water-level area range from less than $10 \mathrm{mg} / \mathrm{L}$ to more than 1,000 $\mathrm{mg} / \mathrm{L}$ (table 3 ). For comparison, the chloride concentration of rainfall is typically less than 10 to $20 \mathrm{mg} / \mathrm{L}$

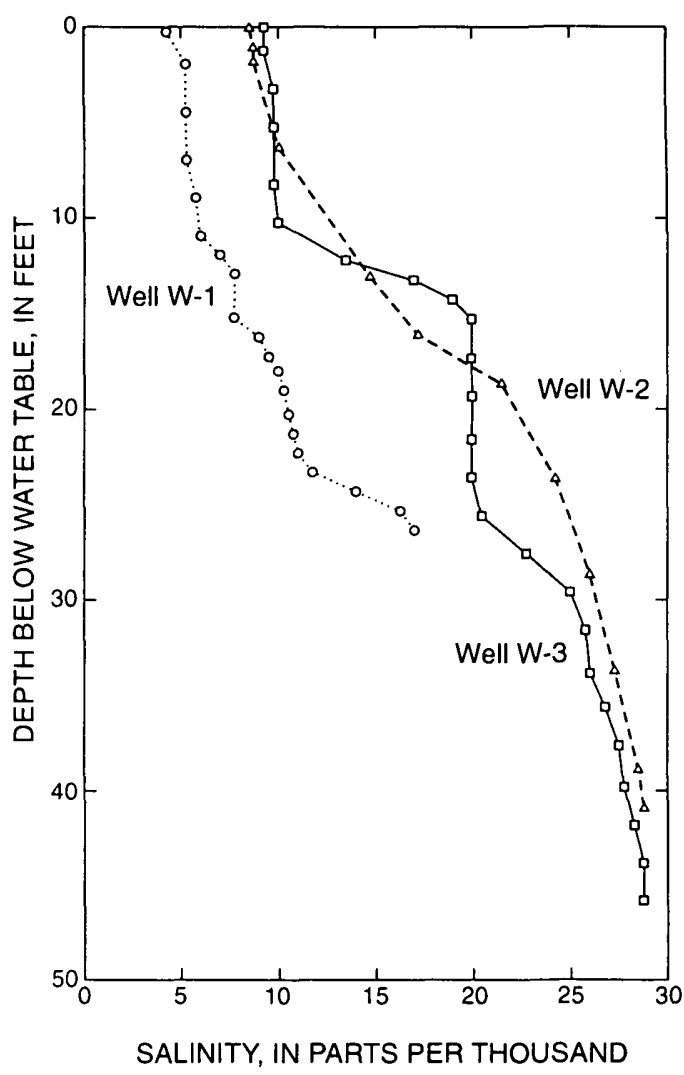

Figure 19. Salinity profiles, measured on June 15 and 21,1991 , in selected monitoring wells, northern Kona, island of Hawaii (modified from Nance, 1991). (Well locations shown in figure 3.)

(Swain, 1973), and the chloride concentration of seawater is about $19,500 \mathrm{mg} / \mathrm{L}$ (Wentworth, 1939).

Long-term records of chloride concentrations are available for eight pumped wells in the Kona area (fig. 20). At six of the eight wells, chloride concentrations of pumped water have remained less than $250 \mathrm{mg} / \mathrm{L}$. Chloride concentrations of pumped water from wells 2753 02 and 3557-05 have exceeded $250 \mathrm{mg} / \mathrm{L}$ in recent years. Chloride concentrations of pumped water have increased as pumping rates have increased (figs. 13 and 20).

\section{GROUND-WATER FLOW SYSTEM}

The ground-water flow system in the Kona area is bounded on the north by the northwest rift zone of Hualalai Volcano, and on the east by the south-southeast rift zone of Hualalai Volcano and the southwest rift zone of Mauna Loa Volcano. The central parts of these rift 
Table 3. Initial available chloride concentration of water from selected wells in the Kona area, island of Hawaii [USGS, U.S. Geological Survey; CWRM, Commission on Water Resource Management; mg/L, milligrams per liter; >, greater than; --, sampling date unknown]

\begin{tabular}{|c|c|c|c|}
\hline Well number & $\begin{array}{c}\text { Chloride } \\
\text { concentration } \\
\text { (mg/L) }\end{array}$ & Date & Source of data \\
\hline $0246-01$ & $>300$ & -- & USGS well file \\
\hline 0953-01 & 700 & $9 / 15 / 80$ & CWRM well completion report \\
\hline $1652-01$ & 110 & $4 / 12 / 93$ & CWRM well completion report \\
\hline 2354-01 & 2,640 & $5 / 5 / 94$ & CWRM well completion report \\
\hline $2554-01$ & $1,140-1,240$ & $7 / 19 / 56$ & USGS well file \\
\hline $2653-01$ & 22 & $8 / 7 / 78$ & CWRM well file \\
\hline $2753-01$ & 90 & $12 / 17 / 58$ & USGS well file \\
\hline $2753-02$ & 108 & $5 / 13 / 63$ & State of Hawaii, 1963 \\
\hline $2753-03$ & 10 & $4 / 7 / 92$ & CWRM well completion report \\
\hline $2755-01$ & 1,350 & $2 / 28 / 74$ & USGS well file \\
\hline $2855-01$ & 1,500 & $2 / 28 / 74$ & USGS well file \\
\hline $3056-01$ & 300 & $2 / 12 / 93$ & CWRM well completion report \\
\hline $3155-01$ & 7 & $5 / 24 / 93$ & USGS well file \\
\hline $3155-02$ & 7 & $5 / 24 / 93$ & USGS well file \\
\hline $3255-01$ & 18 & -- & CWRM well file \\
\hline $3255-02$ & 5 & $8 / 3 / 93$ & CWRM well file \\
\hline $3355-01$ & 5 & $3 / 18 / 91$ & CWRM well completion report \\
\hline $3355-02$ & 5 & $12 / 9 / 92$ & CWRM well completion report \\
\hline $3355-03$ & 6 & $11 / 3 / 93$ & CWRM well completion report \\
\hline $3357-01$ & 1,600 & 1966 & USGS well file \\
\hline $3357-04$ & 1,110 & $6 / 15 / 90$ & CWRM well file \\
\hline $3456-01$ & 220 & $10 / 2 / 89$ & USGS well file \\
\hline $3457-01$ & 1,020 & $6 / 14 / 56$ & USGS well file \\
\hline $3457-02$ & 295 & $10 / 28 / 85$ & USGS well file \\
\hline $3457-03$ & 970 & $1 / 29 / 85$ & CWRM well file \\
\hline $3557-01$ & 8 & $5 / 22 / 59$ & USGS well file \\
\hline $3557-02$ & 13 & $10 / 7 / 59$ & USGS well file \\
\hline $3557-03$ & 8.5 & $2 / 28 / 70$ & USGS well file \\
\hline $3557-04$ & 16 & $2 / 5 / 71$ & USGS well file \\
\hline $3557-05$ & 33 & $4 / 28 / 75$ & USGS well file \\
\hline $3657-01$ & 18 & $4 / 83$ & State of Hawaii, 1984 \\
\hline $3657-02$ & 328 & $12 / 28 / 90$ & CWRM well file \\
\hline $3758-01$ & 696 & $8 / 5 / 44$ & USGS well file \\
\hline $3957-01$ & 10 & $1 / 22 / 93$ & CWRM well file \\
\hline $4057-01$ & 10 & $11 / 15 / 93$ & CWRM well file \\
\hline $4059-01$ & 2,800 & $9 / 17 / 58$ & USGS well file \\
\hline $4060-01$ & $>500$ & $7 / 7 / 95$ & CWRM well completion report \\
\hline $4061-01$ & 3,298 & $5 / 3 / 96$ & USGS well file \\
\hline $4158-02$ & 8 & $8 / 12 / 91$ & CWRM well completion report \\
\hline $4160-01$ & 941 & $8 / 8 / 85$ & CWRM well completion report \\
\hline $4160-02$ & 955 & 1985 & CWRM well completion report \\
\hline $4161-01$ & 5,919 & $5 / 3 / 96$ & USGS well file \\
\hline $4161-02$ & 2,817 & $5 / 3 / 96$ & USGS well file \\
\hline $4258-03$ & 8 & $10 / 12 / 93$ & CWRM well file \\
\hline $4360-01$ & 600 & $9 / 23 / 68$ & State of Hawaii, 1968 \\
\hline 4363-01 & 15,000 & $3 / 5 / 90$ & CWMR well completion report \\
\hline $4458-01$ & 17 & $5 / 30 / 90$ & CWRM well completion report \\
\hline $4458-02$ & 9 & $7 / 15 / 91$ & CWRM well file \\
\hline $4459-01$ & 144 & $3 / 25 / 91$ & CWRM well file \\
\hline $4459-02$ & 110 & $6 / 4 / 92$ & CWRM well completion report \\
\hline $4461-01$ & 2,600 & $4 / 14 / 86$ & USGS well file \\
\hline 4462-02 & 3,825 & $1 / 28 / 93$ & CWRM well completion report \\
\hline $4558-01$ & 20 & $7 / 29 / 91$ & CWRM well file \\
\hline $4558-02$ & 35 & $10 / 5 / 92$ & CWRM well completion report \\
\hline $4559-01$ & 60 & 1985 & CWRM well completion report \\
\hline
\end{tabular}




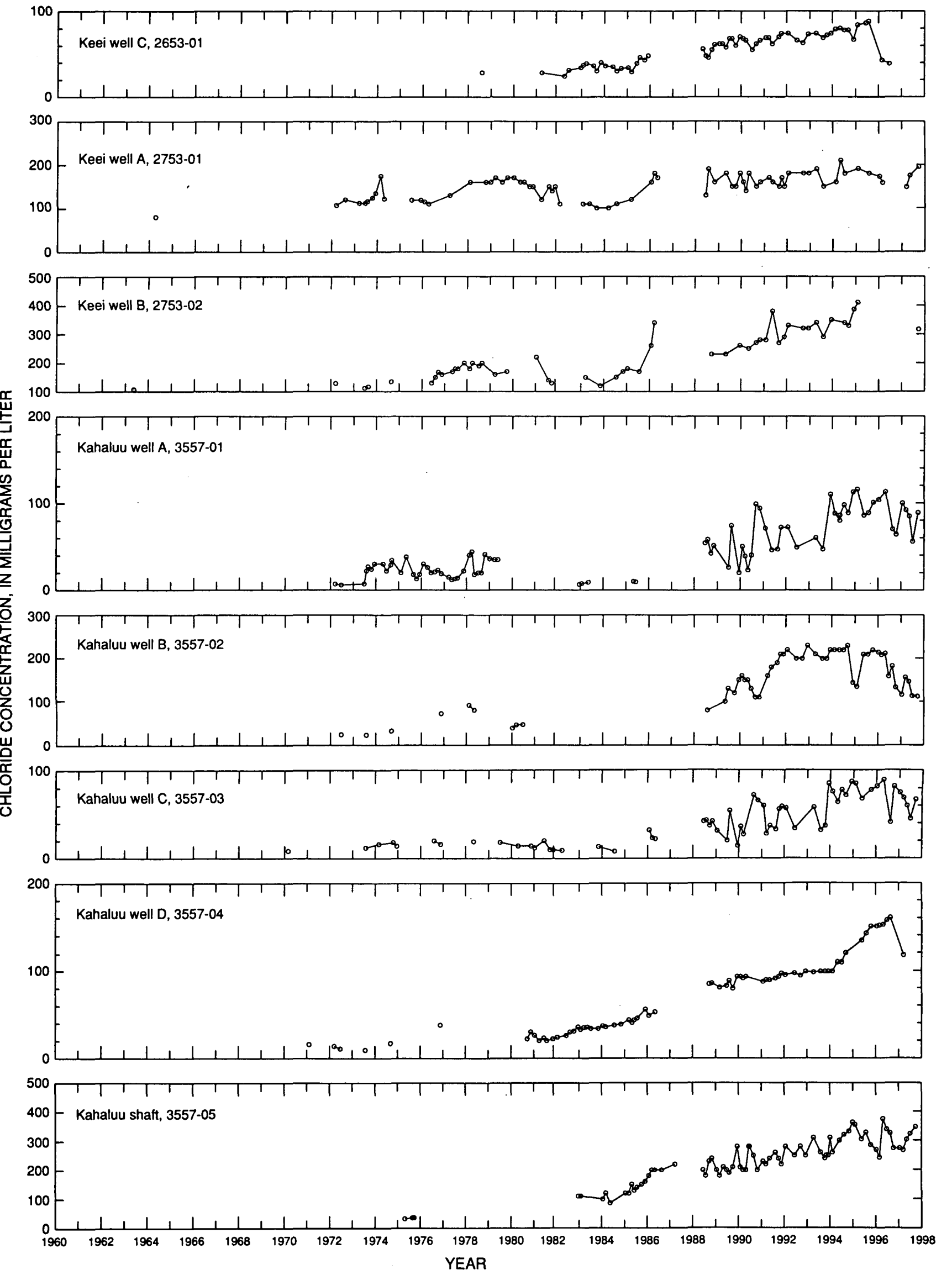

Figure 20. Chloride concentration of water samples from selected wells, Kona, island of Hawaii (data points not connected for data gaps exceeding one year). 
zones are assumed in this study to correspond to ground-water divides.

Ground water is recharged by infiltration of rainfall over most of the Kona study area. Near the coastal and summit areas, however, ground-water recharge rates are low because of the low rainfall and high evaporation rates. The area of greatest recharge lies between altitudes of 2,000 and 6,000 ft, where rainfall and fog drip are greatest. Water that recharges the ground-water system flows from zones of higher to lower hydraulic head, as measured by water levels. Water-level data and geophysical information indicate that ground water generally flows in westward and southward directions, from the mountainous interior areas to coastal discharge areas. Most of the fresh ground water that is not withdrawn from wells eventually discharges naturally from the aquifer at subaerial and submarine coastal springs and seeps. A small amount of ground water may be lost to evaporation and transpiration near the coast. Streams in the Kona area generally do not discharge ground water.

Ground water in the Kona area is generally unconfined in the inland areas. In some inland areas, however, low-permeability rocks may form local confining units.

Seismic-refraction studies (Zucca and others, 1982; Hill and Zucca, 1987) indicated that seismic velocity and density increase at a depth of about 6,000 $\mathrm{ft}$ below the ground surface in the Kona area. The increases in seismic velocity and density were attributed to a reduction of porosity at depth. Although the base of the aquifer in the Kona area is unknown, it may extend down to the depth where seismic velocity and density increase.

Fresh ground water in the Kona area is found in two main forms: (1) as a lens-shaped body of freshwater, called a freshwater lens, floating on denser, underlying saltwater within permeable lava flows near the coast, and (2) as water impounded to high levels within the inland part of the aquifer with lower overall permeability. For the purposes of this report, high water levels are defined as water levels greater than $40 \mathrm{ft}$ above sea level. Fresh ground water flows from the high water-level area to the downgradient freshwater lens, where water levels are generally less than $10 \mathrm{ft}$ above sea level.

\section{Freshwater Lens}

Within the highly permeable, dike-free lava flows near the coast, a lens of freshwater floats on denser, underlying saltwater derived from the ocean. The source of freshwater in the lens is ground-water recharge from (1) the upgradient high water-level area, (2) infiltration of rainfall and fog drip, and (3) irrigation water.

Freshwater in the highly permeable lava flows near the coast exists in only the upper part of the aquifer, and in only a small fraction of the total thickness of the aquifer. Fresh ground water flows from inland areas to coastal discharge areas. Because the volcanic rocks are highly permeable and crop out offshore, freshwater can readily discharge to the ocean, ground-water levels are relatively low (generally less than $10 \mathrm{ft}$ above sea level and commonly less than $5 \mathrm{ft}$ above sea level), and the magnitude of the horizontal head gradient is small (on the order of a foot per mile). In addition, because of the highly permeable offshore volcanic-rock outcrops, saltwater can readily enter the aquifer. A saltwater-circulation system exists beneath the freshwater lens (Cooper and others, 1964; Souza and Voss, 1987). Saltwater flows landward in the deeper parts of the aquifer, rises, and then mixes with seaward-flowing freshwater (fig. 6A). This mixing creates a brackish-water transition zone. In areas near the coast where saltwater mixes thoroughly with seaward-flowing freshwater, a freshwater lens may not form and brackish water may exist immediately below the water table.

For hydrostatic conditions, the thickness of a freshwater lens can be estimated by the Ghyben-Herzberg relation if the freshwater and saltwater are assumed to be immiscible fluids separated by a sharp interface. Assuming specific gravities for freshwater and saltwater of 1.000 and 1.025 , respectively, the GhybenHerzberg relation predicts that every foot of freshwater above sea level must be balanced by $40 \mathrm{ft}$ of freshwater below sea level. Thus, the depth of the freshwatersaltwater interface below sea level is predicted to be 40 times the altitude of the water table above sea level. The estimated freshwater-saltwater interface location is commonly considered to be the location where ground water in the transition zone is a mixture of 50 percent freshwater and 50 percent saltwater. 


\section{High Water-Level Area}

Wells with measured water levels greater than 40 $\mathrm{ft}$ above sea level have been drilled between Kalaoa and Honaunau, at distances ranging from 2 to $4.5 \mathrm{mi}$ inland. In this area, measured water levels generally are between 40 and $500 \mathrm{ft}$ above sea level, but a water level of $1,280 \mathrm{ft}$ above sea level has also been measured. Within the high water-level area, low-permeability rocks compartmentalize the more permeable rocks in which ground water is impounded to high altitudes. Because of this compartmentalization of the aquifer, water levels can change by hundreds of feet over horizontal distances of less than a mile.

Although the freshwater body is known to be more than $300 \mathrm{ft}$ thick in some places, no data exist to evaluate the depth to which rocks are saturated with freshwater in this high water-level area. In addition, no data from wells are available to determine the depth at which saltwater may exist beneath the freshwater body in the high water-level area.

The source of freshwater in the high water-level area is ground-water recharge from (1) infiltration of rainfall and fog drip and (2) irrigation water. Fresh ground water in the high water-level area that is not withdrawn from wells flows to downgradient areas where water levels are lower and where a freshwater lens may exist.

\section{DEVELOPMENT OF GROUND-WATER FLOW MODEL}

A two-dimensional (areal), ground-water flow model using the computer code SHARP (Essaid, 1990) was developed to simulate steady-state ground-water flow in the Kona area. The SHARP code uses a finitedifference approach to simulate flow in a ground-water system containing both freshwater and saltwater and treats freshwater and saltwater as immiscible fluids separated by a sharp interface. In reality, a diffuse transition zone exists between the core of freshwater and the underlying saltwater. In this study, it is assumed that the position of the surface defined by ground water with 50 percent seawater salinity (a mixture of half freshwater and half saltwater) is approximated by the sharp interface position. The SHARP code simulates vertically averaged freshwater heads and vertically averaged salt- water heads in the aquifer and assumes that flow within a model layer is entirely horizontal.

\section{Model Construction}

A steady-state ground-water flow model for the Kona area was developed to simulate measured groundwater levels from 1991-93. This period was selected because (1) ground-water withdrawals were relatively steady during this period, (2) there were no groundwater withdrawals from the high water-level area, (3) the best available spatial distribution of water-level measurements are from this period, and (4) there were no significant water-level trends, particularly outside of the high water-level area (fig. 17), during this period.

Since 1994, ground water has been withdrawn from the high water-level area, which caused water levels in some wells in this area to decline. The ultimate position to which water levels will decline for pumping conditions in the high water-level area is presently unknown. Consequently, it was desirable to avoid simulating withdrawals from the high water-level area for model construction. Withdrawals from the high waterlevel area were, however, simulated in the 1997 base case and future scenarios described in a later section of this report.

The model accounts for spatially varying hydraulic characteristics of the geologic materials, recharge, and ground-water withdrawals. The hydraulic characteristics were estimated from available data and were modified by varying them in the model to obtain acceptable agreement between measured and model-calculated water levels. However, the spatial coverage of measured water levels (fig. 15) is not adequate to calibrate a numerical ground-water flow model.

\section{Model Grid}

The finite-difference grid used in this study consists of 9,135 cells, arranged in a rectangular array with 145 rows and 63 columns, and has a geographic origin (upper left hand, or northwest corner) at longitude $156^{\circ} 09^{\prime} 03^{\prime \prime}$ and latitude $19^{\circ} 48^{\prime} 18^{\prime \prime}$ (fig. 21). The long side of the model grid is oriented $\mathrm{N} 15^{\circ} \mathrm{W}$. The model grid covers the entire Kona study area below a land-surface altitude of $6,000 \mathrm{ft}$. Although recharge within the study area above a land-surface altitude of $6,000 \mathrm{ft}$ was included in the model, ground-water flow in these areas 


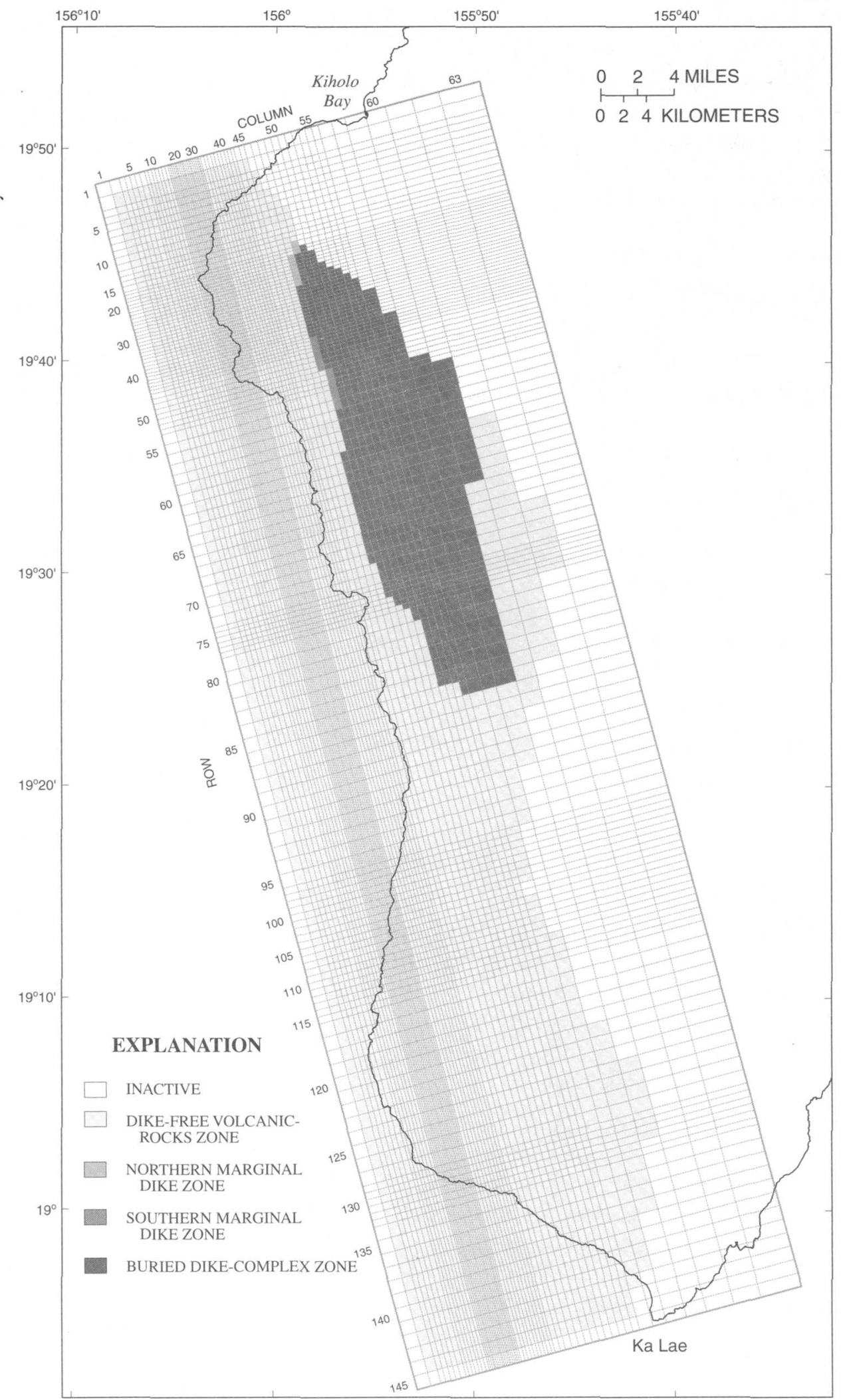

Base modified from U.S. Geological Survey digital data,

1:24,000, 1983, Albers equal area projection, standard

parallels $19^{\circ} 08^{\prime} 30^{\prime \prime}$ and $20^{\circ} 02^{\prime} 30^{\prime \prime}$, central meridian

$155^{\circ} 26^{\prime} 30^{\prime \prime}$

Figure 21. Finite-difference model grid and hydraulic-conductivity zones for the Kona area, island of Hawaii. 
was not modeled because ground-water conditions are uncertain. The active part of the grid extends at least a mile offshore to include the entire zone where fresh ground water discharges to the ocean. Within the active part of the grid, the grid spacing ranges from 500 to $8,000 \mathrm{ft}$. Grid spacing is finest near the coast where ground water discharges.

\section{Boundary Conditions}

SHARP supports three types of boundary conditions: (1) specified head, (2) specified flow (which includes no flow), and (3) head-dependent discharge. Specified-head boundary conditions were not used for this study. The outer rows and columns of the grid are no-flow boundaries in the SHARP code.

The aquifer bottom is treated as a no-flow boundary. Onshore, the aquifer bottom was assumed to exist at a depth of $6,000 \mathrm{ft}$ below the land surface, and offshore, the aquifer bottom was assumed to exist $6,000 \mathrm{ft}$ below the ocean floor. Interior areas above an altitude of $6,000 \mathrm{ft}$ were not modeled.

The central parts of the northwest and south-southeast rift zones of Hualalai and the southwest rift zone of Mauna Loa were used to define the boundaries of the study area and were assumed to correspond to groundwater divides. In the model, the central parts of these rift zones were assumed to be no-flow boundaries, and areas inland of the central parts of the rift zones were not modeled. Thus, the inland boundary of the modeled area is formed by either a rift zone or the $6,000-\mathrm{ft}$ landsurface contour.

All cells representing offshore areas and subaerial springs near the coast were modeled using a headdependent discharge boundary condition. All cells not simulated as a head-dependent discharge boundary are unconfined cells (fig. 22).

Freshwater flow out of the model at head-dependent discharge cells is assumed to be linearly related to the difference between the head in the aquifer and the head overlying the aquifer at the discharge site according to the equation:

$$
Q=\left(K^{\prime} / B^{\prime}\right) A\left(h-h_{0}\right)
$$

where:

$Q$ is the rate of discharge from a model cell $\left[\mathrm{L}^{3} / \mathrm{T}\right]$, $K^{\prime}$ is the vertical hydraulic conductivity of the confining unit overlying the aquifer $[\mathrm{L} / \mathrm{T}]$,
$B^{\prime}$ is the thickness of the confining unit overlying the aquifer [L],

$A$ is the area of the model cell $\left[\mathrm{L}^{2}\right]$,

$h$ is the head in the aquifer [L], and

$h_{0}$ is the head, measured relative to mean sea level, above the aquifer [L].

The vertical hydraulic conductivity of the confining unit divided by the confining-unit thickness is termed the coastal leakance in this report. Although a low-permeability coastal confining unit does not exist in the Kona area, the volcanic rocks do impede the discharge of ground water to the ocean. Thus, in the model, the vertical hydraulic conductivity of the confining unit is represented by the vertical hydraulic conductivity of the volcanic-rock aquifer, and the confining-unit thickness is represented by the aquifer thickness over which vertical discharge occurs. No attempt was made to estimate separate values for aquifer thickness over which vertical discharge occurs and vertical hydraulic conductivity for the Kona area; instead, the coastal leakance, which was assumed to be spatially constant, was estimated by trial and error.

The head, $h_{0}$, overlying the aquifer above onshore coastal-discharge cells is unknown but is probably near mean sea level, and is assumed to be zero. For offshore cells, $h_{0}$ was assigned a value corresponding to the freshwater-equivalent head of the saltwater column overlying the ocean floor within the cell. The freshwater-equivalent head, measured relative to a mean sealevel datum, was computed from the equation:

$$
h_{0}=-Z / 40
$$

where $Z$ is the altitude of the ocean floor (fig. 22).

\section{Hydraulic-Conductivity Zones}

The Kona study area was divided into four horizontal hydraulic-conductivity zones: (1) dike-free volcanic rocks of Hualalai and Mauna Loa, (2) buried Hualalai dike complex, (3) northern marginal dike zone (north of Kalaoa) where measured water levels range from about 6 to $13 \mathrm{ft}$, and (4) southern marginal dike zone inland of Kailua, between Palani Junction and Holualoa, where measured water levels range from about 40 to $200 \mathrm{ft}$ (fig. 21). It was necessary to create these four zones to adequately and efficiently represent the ground-water flow system. Available hydrologic and geologic information were considered insufficient to justify creation of additional zones. No hydraulic 


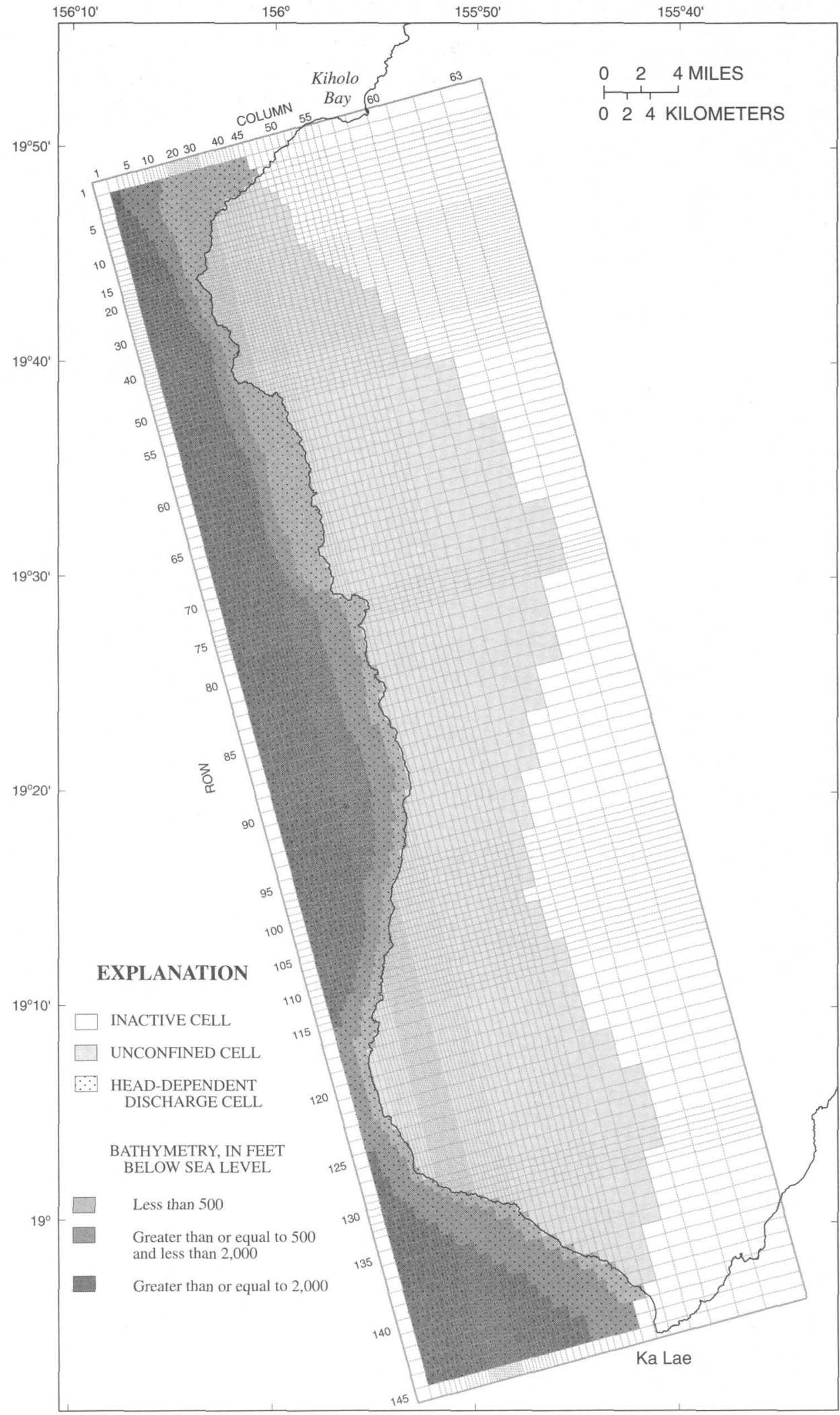

Base modified from U.S. Geological Survey digital data, $1: 24,000,1983$, Albers equal area projection, standard parallels $19^{\circ} 08^{\prime} 30^{\prime \prime}$ and $20^{\circ} 02^{\prime} 30^{\prime \prime}$, central meridian $155^{\circ} 26^{\prime} 30^{\prime \prime}$

Figure 22. Finite-difference model grid and head-dependent discharge cells for the Kona area, island of Hawaii. 
Table 4. Description of pumped wells and reported pumping rates, Kona area, island of Hawaii [Mgal/d, million gallons per day; --, top of shaft is near the water table]

\begin{tabular}{|c|c|c|c|c|c|}
\hline Well number & $\begin{array}{l}\text { Altitude of top } \\
\text { of open interval } \\
\text { (feet) }\end{array}$ & $\begin{array}{l}\text { Altitude of bottom } \\
\text { of open interval } \\
\text { (feet) }\end{array}$ & $\begin{array}{c}\text { Model cell } \\
\text { (row,column) }\end{array}$ & $\begin{array}{c}1991-93 \\
\text { pumping rate } \\
\text { (Mgal/d) }\end{array}$ & $\begin{array}{c}1997 \\
\text { pumping rate } \\
\text { (Mgal/d) }\end{array}$ \\
\hline 0952-01 & 0 & -25 & 117,31 & 0.35 & 0.08 \\
\hline 0953-01 & -2 & -32 & 116,25 & 0.16 & 0.04 \\
\hline $2653-01$ & -1 & -31 & 81,50 & 0.55 & 0.08 \\
\hline $2753-01$ & -26 & -36 & 80,50 & 0.19 & 0.12 \\
\hline $2753-02$ & 2 & -37 & 80,50 & 0.20 & 0.11 \\
\hline $2753-03$ & 364 & 4 & 79,52 & 0.00 & 0.48 \\
\hline $3155-02$ & 491 & 1 & 69,48 & 0.00 & 0.28 \\
\hline $3357-04$ & 2 & -18 & 64,44 & 0.00 & 0.33 \\
\hline $3457-01$ & 3 & -24 & $61,43 a$ & 0.00 & 0.50 \\
\hline $3457-03$ & -1 & -21 & 61,44 & 0.00 & 0.17 \\
\hline $3557-01$ & -31 & -51 & 60,46 & 0.62 & 0.74 \\
\hline $3557-02$ & -30 & -42 & 61,46 & 0.98 & 0.87 \\
\hline $3557-03$ & 15 & -34 & 60,46 & 0.55 & 0.67 \\
\hline $3557-04$ & 3 & -50 & 61,46 & 1.33 & 0.22 \\
\hline $3557-05$ & -- & -5 & 60,45 & 4.86 & 4.73 \\
\hline $3657-01$ & -2 & -45 & 57,47 & 0.55 & 0.14 \\
\hline $4057-01$ & 60 & -25 & 48,49 & 0.00 & 0.96 \\
\hline 4358-01 & 69 & -51 & 29,48 & 0.00 & 0.42 \\
\hline $4363-01$ to -10 & -5 & -17 & 19,18 & 2.88 & 2.88 \\
\hline $4459-01$ & 0 & -84 & 19,48 & 0.13 & 0.00 \\
\hline $4459-02$ & -3 & -93 & 18,48 & 0.00 & 0.07 \\
\hline $4558-01$ & 4 & -79 & 15,49 & 0.00 & 0.10 \\
\hline $4559-01$ & 0 & -111 & 17,49 & 0.21 & 0.00 \\
\hline Total & & & & 13.6 & 14.0 \\
\hline
\end{tabular}

distinction was made between the dike-free volcanic rocks of Hualalai and Mauna Loa. The buried Hualalai dike-complex zone was located using available hydrologic and geophysical information, and was modeled as a zone of lower overall hydraulic conductivity relative to the dike-free volcanic-rocks zone. On the basis of measured water levels, model zones were created for locations where marginal dike zones (the northern and southern marginal dike zones) are presumed to exist. The hydraulic conductivity of the marginal dike zones lies between the values for the dike-free volcanic rocks and the buried Hualalai dike complex.

\section{Aquifer-Storage Properties}

Although the values for aquifer porosity and specific storage generally are not relevant in a steady-state ground-water flow model, SHARP requires that values for these properties be specified. A constant value of 0.1 was arbitrarily assigned for porosity. Constant freshwater and saltwater specific-storage values used in the model were $7.6 \times 10^{-6}$ per $\mathrm{ft}$ and $7.8 \times 10^{-6}$ per $\mathrm{ft}$, respectively. These specific-storage values were computed by assuming an aquifer matrix compressibility of $1.2 \times 10^{-7} \mathrm{ft}^{2} / \mathrm{b}$, a value estimated for southern Oahu by Souza and Voss (1987).

\section{Ground-Water Withdrawals}

Ground-water withdrawals in the Kona area during the period 1991-93 averaged 13.6 Mgal/d (table 4) from 23 wells (computed from unpub. data from Hawaii Commission on Water Resource Management). During this period, there were no reported withdrawals from the high water-level area. Unreported withdrawals from wells in the study area are probably small and are not represented in the model. For model cells containing a single pumped well, the reported top and bottom of the open well interval were used in the model (table 4). For model cells containing more than one pumped well, a flow-weighted average well depth was used in the model.

\section{Recharge}

Average annual recharge of $357.5 \mathrm{Mgal} / \mathrm{d}$ was assumed to be representative of the period 1991-93. Annual rainfall data for 1991-93 were available at only four stations in the Kona area. At stations 24.1, 27.4, 68.13, and 68.2 (U.S. Weather Bureau stations 7166, 8552,3911 , and 5330 , respectively) (fig. 8 ), the ratio of average annual rainfall for 1991-93 to average annual rainfall for the available period of record ranged from 
0.64 to 1.08 . However, on the basis of ground-waterlevel information and the persistence of fog drip in the area, it is expected that recharge for the period 1991-93 probably did not vary greatly from the annual average value.

The areal distribution of recharge used in the model is shown in figure 23. For cells lying along the 6,000 - $\mathrm{ft}$ altitude boundary, recharge was added to account for recharge outside the model between the 6,000-ft level and the assumed inland ground-water divide, which is defined by the central parts of the northwest and south-southeast rift zones of Hualalai and the southwest rift zone of Mauna Loa. Within a given row of the model grid, recharge in the Kona study area above an altitude of $6,000 \mathrm{ft}$ was added to the easternmost active cell of the grid.

\section{Water Properties}

The specific weights for freshwater and saltwater were assumed to be $62.41 \mathrm{lb} / \mathrm{ft}^{3}$ and $63.97 \mathrm{lb} / \mathrm{ft}^{3}$ (Essaid, 1990), respectively. Hydraulic conductivity is dependent on fluid viscosity, which is in turn a function of temperature and, to a lesser extent, pressure and salinity. The freshwater and saltwater dynamic viscosities used in the model were $2.09 \times 10^{-5} \mathrm{lb} \bullet \mathrm{s} / \mathrm{ft}^{2}$ and $2.24 \times$ $10^{-5} \mathrm{lb} \cdot \mathrm{s} / \mathrm{ft}^{2}$ (Weast and others, 1989), respectively, for an assumed temperature of $20^{\circ} \mathrm{C}$.

\section{Estimation of Hydraulic Characteristics}

The sequence of steps used to estimate the hydraulic characteristics (table 5) are described below.

1. A set of 16 simulations was made to determine the effects of the assigned values for coastal leakance and horizontal hydraulic conductivity of the buried dike complex on model-calculated water levels in the dike-complex zone. In this set, zones were combined in an attempt to produce an efficient representation of the system. The southern marginal dike zone inland of Kailua was grouped with the buried Hualalai dike-complex zone, and the northern marginal dike zone was grouped with the dikefree volcanic-rocks zone. The horizontal hydraulic conductivity of the dike-free volcanic-rocks zone and the northern marginal dike zone was assigned a value of 7,500 ft/d for all 16 simulations. (Note that model-calculated water levels in the dike-complex zone were not significantly affected by the value of horizontal hydraulic conductivity assigned to the dike-free volcanic rocks zone within the plausible range tested in step 2 below.) All possible combinations of four values of each of two different hydraulic characteristics $(4 \times 4=16)$ were used:

(1) values of $0.075,0.1,0.25$, and $0.5 \mathrm{ft} / \mathrm{d}$ for the horizontal hydraulic conductivity in the combined zone consisting of the buried Hualalai dike-complex and southern marginal dike zone inland of Kailua, and (2) values of $0.05,0.1,1.0$ and $5.0 \mathrm{ft} / \mathrm{d} / \mathrm{ft}$ for the coastal leakance. Results of these simulations (appendix A) indicate that (1) model-calculated water levels in the dike-complex zone are not significantly affected by the value of the coastal leakance, and (2) a value of $0.1 \mathrm{ft} / \mathrm{d}$ for the horizontal hydraulic conductivity of the dike-complex zone produced the smallest errors (average difference, average absolute difference, and root-mean-square of the difference) between model-calculated and measured water levels in the high water-level area.

2. A set of 16 simulations was made to determine the effects of the assigned values for coastal leakance and horizontal hydraulic conductivity of the dike-free volcanic rocks on model-calculated water levels in the dike-free volcanic-rocks zone. Zones were combined as described in step 1. The horizontal hydraulic conductivity of the dike-complex zone and the southern marginal dike zone inland of Kailua was assigned a value of $0.1 \mathrm{ft} / \mathrm{d}$ for all 16 simulations. (Note that model-calculated water levels in the dike-free volcanic-rocks zone were not significantly affected by the value of horizontal hydraulic conductivity assigned to the dike-complex zone within the plausible range tested in step 1 above.) All possible combinations of four values of each of two different hydraulic characteristics $(4 \times 4=16)$ were used: (1) values of 2,$500 ; 5,000$; 7,500 ; and $10,000 \mathrm{ft} / \mathrm{d}$ for the horizontal hydraulic conductivity in the combined zone consisting of the dike-free volcanic rocks and northern marginal dike zone, and (2) values of $0.05,0.1,1.0$ and $5.0 \mathrm{ft} / \mathrm{d} / \mathrm{ft}$ for the coastal leakance. Results of these simulations (appendix A) indicate that a value of 7,500 ft/d for the horizontal hydraulic conductivity of the combined zone consisting of the dike-free volcanic rocks and northern marginal dike zone, in conjunction with a value of $0.05 \mathrm{ft} / \mathrm{d} / \mathrm{ft}$ for the coastal leakance, produced the smallest errors (average difference, average absolute difference, and root-mean- 


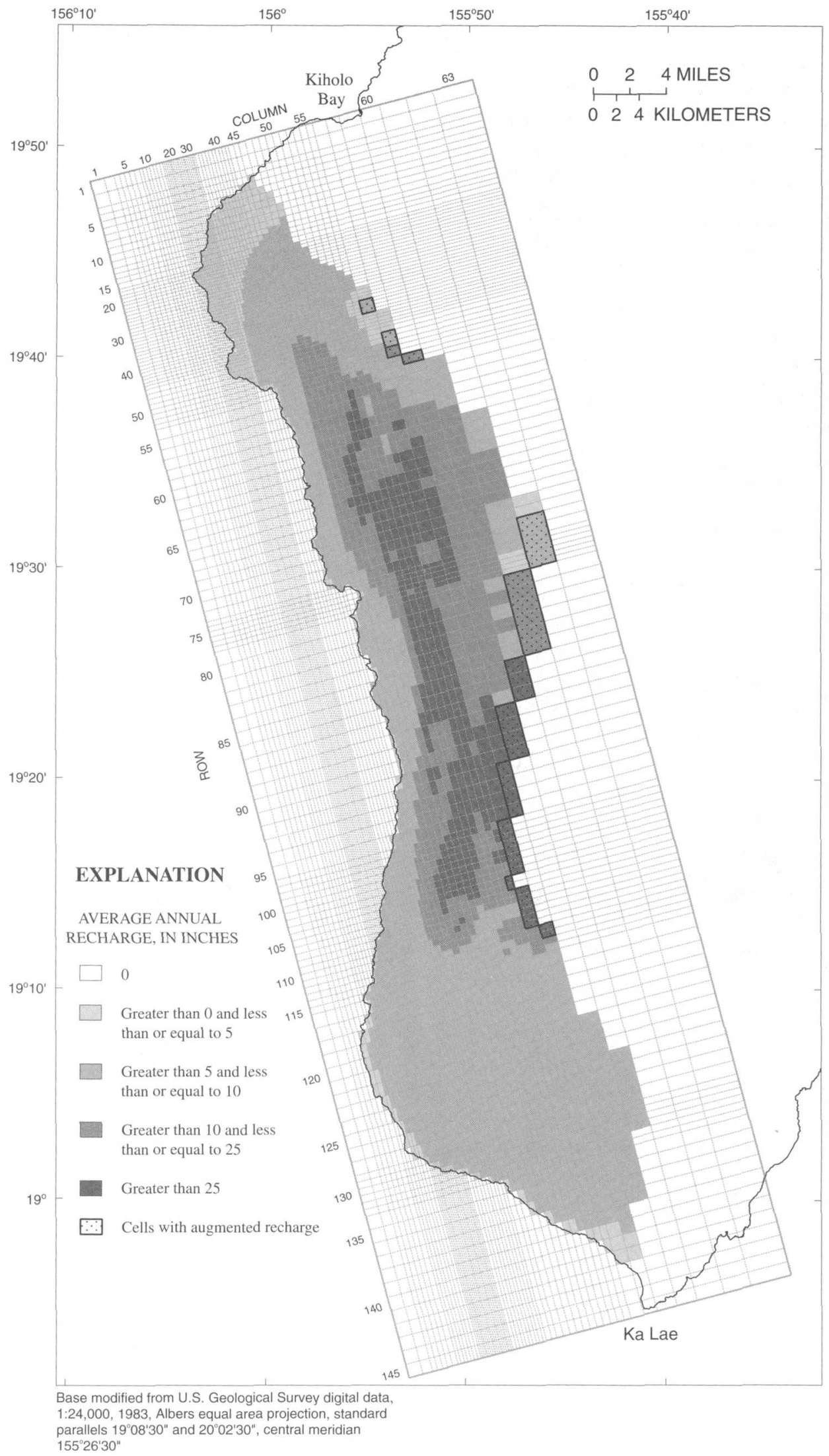

Figure 23. Average annual recharge used in the ground-water flow model for the Kona area, island of Hawaii. 
square of the difference) between model-calculated and measured water levels in the dike-free volcanic rocks seaward of the high water-level area and north of Kealakekua Bay where data are most reliable.

3. Results from steps 1 and 2 indicate that it is not possible to properly simulate water levels in the marginal dike zones if these zones are incorporated with the dike-complex zone or the dike-free volcanic-rocks zone. Thus, in this step, the two marginal dike zones were treated as separate model zones. A trial-and-error procedure was used to estimate the final values of two hydraulic characteristics: (1) a horizontal hydraulic conductivity of 0.5 $\mathrm{ft} / \mathrm{d}$ for the southern marginal dike zone inland of Kailua (note that this zone was combined with the dike-complex zone in steps 1 and 2), and (2) a horizontal hydraulic conductivity of $10 \mathrm{ft} / \mathrm{d}$ for the northern marginal dike zone (note that this zone was combined with the dike-free volcanics rocks zone in steps 1 and 2).

Table 5. Final parameter values used in the Kona groundwater flow model, island of Hawaii [ft/d/ft, feet per day per foot]

\begin{tabular}{cc}
\hline & $\begin{array}{c}\text { Hydraulic conductivity } \\
\text { (feet per day) }\end{array}$ \\
\hline Model zone & 7,500 \\
Dike-free volcanic rocks & 0.1 \\
Buried dike complex & 10 \\
Northern marginal dike zone & 0.5 \\
Southern marginal dike zone & leakance $=0.05 \mathrm{ft} / \mathrm{d} / \mathrm{ft}$ \\
\hline
\end{tabular}

\section{Model-Calculated Water Levels}

The model-calculated water levels are in general agreement with the limited set of measured water levels (figs. 24 and 25). In the scatter plot (fig. 24), different symbols are used to represent the water levels from wells in different geographic areas. For the 1991-93 measured water levels from 20 wells outside of the high water-level area, the average, average-absolute, and root-mean-square of the differences between measured and model-calculated water levels were $-0.6,1.3$, and $1.9 \mathrm{ft}$, respectively. For the 1991-93 measured water levels from 15 wells in the high water-level area, the average, average-absolute, and root-mean-square of the differences were $-37.3,79.2$, and $101.8 \mathrm{ft}$, respectively. For the measured water levels from five wells in the

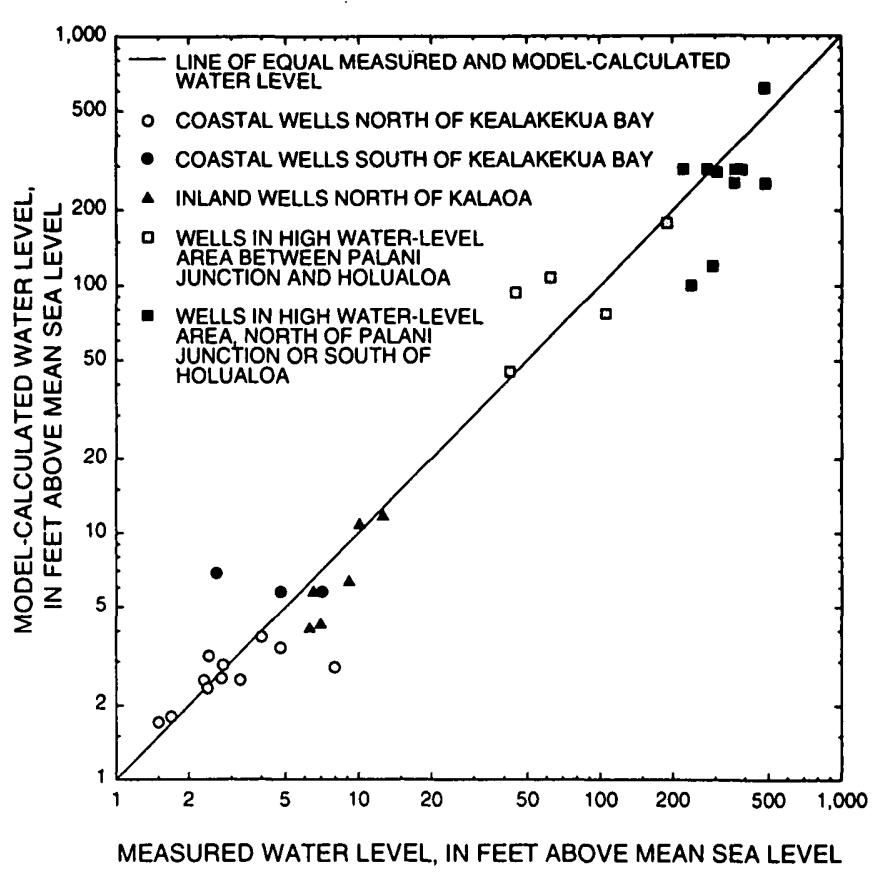

Figure 24. Measured and model-calculated water levels for 1991-93 pumping conditions, Kona, island of Hawaii, for a coastal leakance of 0.05 feet per day per foot, a horizontal hydraulic conductivity of 7,500 feet per day for the dike-free, volcanic-rocks zone, a horizontal hydraulic conductivity of 0.1 feet per day for the dike-complex zone, a horizontal hydraulic conductivity of 0.5 feet per day for the southern marginal dike zone, and a horizontal hydraulic conductivity of 10 feet per day for the northern marginal dike zone.

high water-level area between Palani Junction and Holualoa, the average, average-absolute, and rootmean-square of the differences were 11.4, 27.4, and $32.9 \mathrm{ft}$, respectively.

Model results indicate that water levels do not strictly increase in an inland direction and that a groundwater divide exists within the buried dike complex (fig. 25). Ground water to the west of this divide that is not withdrawn by wells flows toward coastal discharge areas. Ground water that originates from the buried dike complex to the east of this divide flows in an easterly, inland direction, then in a southerly direction around the southern extent of the low-permeability buried dike complex, and then in a southwesterly direction toward coastal discharge areas. Thus, model results indicate that the low-permeability buried dike complex may cause ground water to flow in directions that are not directly from inland areas to the coast. Data are not available, however, to verify model results in areas 


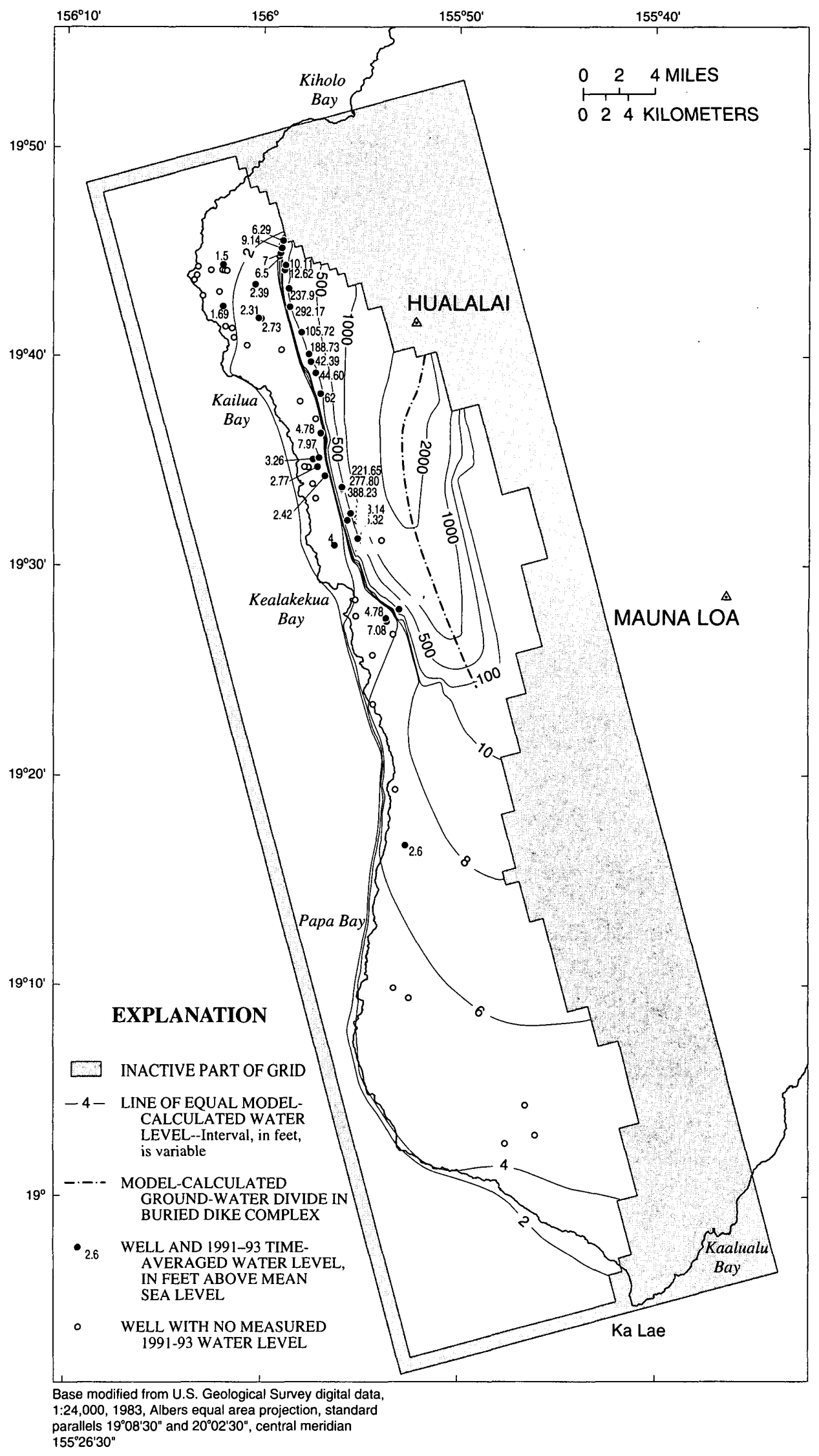

Figure 25. Model-calculated and measured 1991-93 water levels for the Kona area, island of Hawaii. 
where the model results indicate that ground water flows in an inland direction.

\section{Model-Calculated Ground-Water Discharge}

In the model, the amount of freshwater and saltwater extracted from a well is linearly apportioned according to the proportion of the open interval of the well (table 4) that exists in the freshwater and saltwater zones. Thus, wells that are screened or open entirely above the model-calculated freshwater-saltwater interface are assumed to extract only freshwater. For a well with half its open interval above the model-calculated freshwater-saltwater interface and half its open interval below the model-calculated interface, the SHARP model assigns half the total pumpage to the freshwater zone and half to the saltwater zone. For 1991-93 conditions, total ground-water withdrawal represented in the model was $13.6 \mathrm{Mgal} / \mathrm{d}$. Model results indicate that 13.0 $\mathrm{Mgal} / \mathrm{d}$ is withdrawn from the freshwater zone (above the freshwater-saltwater interface) and $0.6 \mathrm{Mgal} / \mathrm{d}$ is withdrawn from the saltwater zone (below the freshwater-saltwater interface) (table 6). All of the modelcalculated saltwater withdrawal was from wells 436301 to -10 , and this is consistent with the high measured chloride concentration of $15,000 \mathrm{mg} / \mathrm{L}$ in water from well 4363-01 (table 3).

Under natural conditions, in the absence of human activity, a ground-water system will typically approach a steady-state condition with the average rate of discharge equal to the average rate of recharge. If ground water is withdrawn from the aquifer at a constant rate, the ground-water system will eventually approach a new steady-state condition with lower heads and a reduced rate of discharge (from onshore and offshore springs and seeps) equal to the average recharge rate minus the withdrawal rate. This situation is reflected in the steady-state water-budget summary of table 6 . Model-calculated freshwater discharge at the coast from springs and seeps is $344.5 \mathrm{Mgal} / \mathrm{d}$. For steadystate conditions, this freshwater coastal discharge rate is equal to the recharge rate of $357.5 \mathrm{Mgal} / \mathrm{d}$ minus the freshwater withdrawal rate of $13.0 \mathrm{Mgal} / \mathrm{d}$. About 96 percent of the total model-calculated freshwater discharge is coastal discharge, and the remainder (4 percent) is ground-water withdrawal from wells (table 6).
Table 6. Recharge used in the model and distribution of model-calculated ground-water discharge, Kona, island of Hawaii

\begin{tabular}{lcr}
\hline & $1991-93$ & 1997 \\
\hline Recharge, in million gallons per day & 357.5 & 357.5 \\
Discharge, in million gallons per day & & \\
Freshwater pumpage & 13.0 & 13.3 \\
Saltwater pumpage & 0.6 & 0.7 \\
Coastal freshwater discharge & 344.5 & 344.2 \\
\hline
\end{tabular}

\section{Model Sensitivity to Recharge}

Because of the uncertainty in the recharge estimate, two additional simulations were made to assess the model sensitivity to recharge. (Model sensitivity to the hydraulic characteristics is addressed in appendix A.) The estimated recharge of $357.5 \mathrm{Mgal} / \mathrm{d}$ was uniformly reduced by 25 percent in one simulation and uniformly increased by 25 percent in the second simulation. All other quantities, including the estimated hydraulic characteristics (table 5) and 1991-93 withdrawal rates, were not changed for the sensitivity analysis.

For a given distribution of hydraulic-conductivity and coastal-leakance values, model-calculated water levels are directly related to the recharge rate used in the model. Model-calculated water-level changes, relative to the simulation with $357.5 \mathrm{Mgal} / \mathrm{d}$ recharge, caused by changes in recharge were computed at the sites where measured water levels from 1991-93 were available. For a total recharge rate of $268.1 \mathrm{Mgal} / \mathrm{d}$, the average model-calculated water-level decrease is $37.5 \mathrm{ft}$ at the locations of 15 wells in the high water-level area, and the average model-calculated water-level decrease is $0.8 \mathrm{ft}$ for the 20 wells outside the high water-level area. For a total recharge rate of $446.9 \mathrm{Mgal} / \mathrm{d}$, the average model-calculated water-level increase is $35.2 \mathrm{ft}$ at the locations of 15 wells in the high water-level area, and the average model-calculated water-level increase is 0.7 $\mathrm{ft}$ for the 20 wells outside the high water-level area. For the range of values tested, the model does not appear to be highly sensitive to recharge rate. 


\section{EFFECTS OF PROPOSED WITHDRAWALS}

The final hydraulic-conductivity and coastalleakance values (table 5) described in the previous section were used to simulate steady-state water levels and discharges for a 1997 base-case scenario. This base case was used as a reference for computing steady-state water-level drawdown and ground-water coastal discharge reduction for three different proposed withdrawal scenarios in which withdrawals from the high water-level area between Palani Junction and Holualoa were increased relative to average 1997 rates. The model developed for this study was not used to optimize ground-water withdrawals from the high water-level area. Thus, it is possible that with optimal well siting and pumping rates, fresh ground water can be withdrawn at rates greater than indicated by the scenarios tested.

\section{Simulation of Average 1997 Conditions}

Long-term average recharge, estimated to be 357.5 $\mathrm{Mgal} / \mathrm{d}$, and average 1997 ground-water withdrawal rates were used in the 1997 base-case scenario. Average reported withdrawal rates from wells during 1997 were computed from data provided by CWRM. Total average pumpage from wells during 1997 was $14.0 \mathrm{Mgal} / \mathrm{d}$, which includes an estimated saline-water withdrawal of $2.88 \mathrm{Mgal} / \mathrm{d}$ from wells $4363-01$ to -10 (table 4). For 1997 conditions, steady-state model results indicate that $13.3 \mathrm{Mgal} / \mathrm{d}$ is withdrawn from the freshwater zone and $0.7 \mathrm{Mgal} / \mathrm{d}$ is withdrawn from the saltwater zone (table 6).

Ground-water withdrawals from the high waterlevel area increased from zero for the period 1991-93 to 2.1 Mgal/d for the 1997 base-case scenario. Because of this increase in withdrawals from the high water-level area, model-calculated steady-state water levels within the high water-level area for average 1997 withdrawal rates (fig. 26) are lower than the model-calculated steady-state water levels for 1991-93 withdrawal rates (fig. 25) by as much as $85 \mathrm{ft}$ in the immediate vicinity of well 4057-01.

Outside the high water-level area, model-calculated steady-state water levels for average 1997 withdrawal rates generally are lower than model-calculated water levels from the 1991-93 simulation period by 0.1 $\mathrm{ft}$ or less. In some areas, however, model-calculated steady-state water levels for average 1997 withdrawal rates are higher than model-calculated water levels from the 1991-93 simulation period. For example, near wells 3557-01 to -05 , model-calculated steady-state water levels for 1997 withdrawal rates are about $0.09 \mathrm{ft}$ higher than model-calculated water levels from the 1991-93 simulation period.

Model-calculated freshwater discharge at the coast from springs and seeps is $344.2 \mathrm{Mgal} / \mathrm{d}$ (table 6). For steady-state conditions, this freshwater coastal discharge rate is equal to the recharge rate of $357.5 \mathrm{Mgal} / \mathrm{d}$ minus the freshwater withdrawal rate of $13.3 \mathrm{Mgal} / \mathrm{d}$. About 96 percent of the total model-calculated freshwater discharge is coastal discharge, and the remainder (4 percent) is ground-water withdrawal from wells (table 6).

\section{Simulation of the Hydrologic Effects of Additional Withdrawals}

The ground-water flow model developed for this study is the best available tool for qualitatively demonstrating the potential hydrologic effects of additional withdrawals on ground-water levels and coastal discharge in the Kona area. To estimate these hydrologic effects, three additional scenarios were simulated.

Average annual recharge of $357.5 \mathrm{Mgal} / \mathrm{d}$ (fig. 23) was used for all three scenarios. The initial condition used for all three scenarios was the model-calculated steady-state water levels from the 1997 base-case scenario. In all three scenarios, additional water was withdrawn from the high water-level area between Palani Junction and Holualoa. In the 1997 base-case scenario, $0.96 \mathrm{Mgal} / \mathrm{d}$ was withdrawn from this area from well 4057-01. In scenario 1, the total proposed ground-water withdrawal rate in the high water-level area between Palani Junction and Holualoa was increased to 25.6 $\mathrm{Mgal} / \mathrm{d}$. In scenarios 2 and 3, the total proposed groundwater withdrawal rates in the high water-level area between Palani Junction and Holualoa were $9.0 \mathrm{Mgal} / \mathrm{d}$ and 5.0 Mgal/d, respectively. In all three scenarios, the withdrawals were distributed among seven wellfields, corresponding to 12 model cells (table 7). The distribution of proposed withdrawals simulated in scenario 1 is the recommended distribution from the North Kona Water Master Plan (State of Hawaii, 1995, fig. VIII-1), whereas the proposed withdrawals simulated in scenarios 2 and 3 were uniformly distributed among the 12 model cells. 


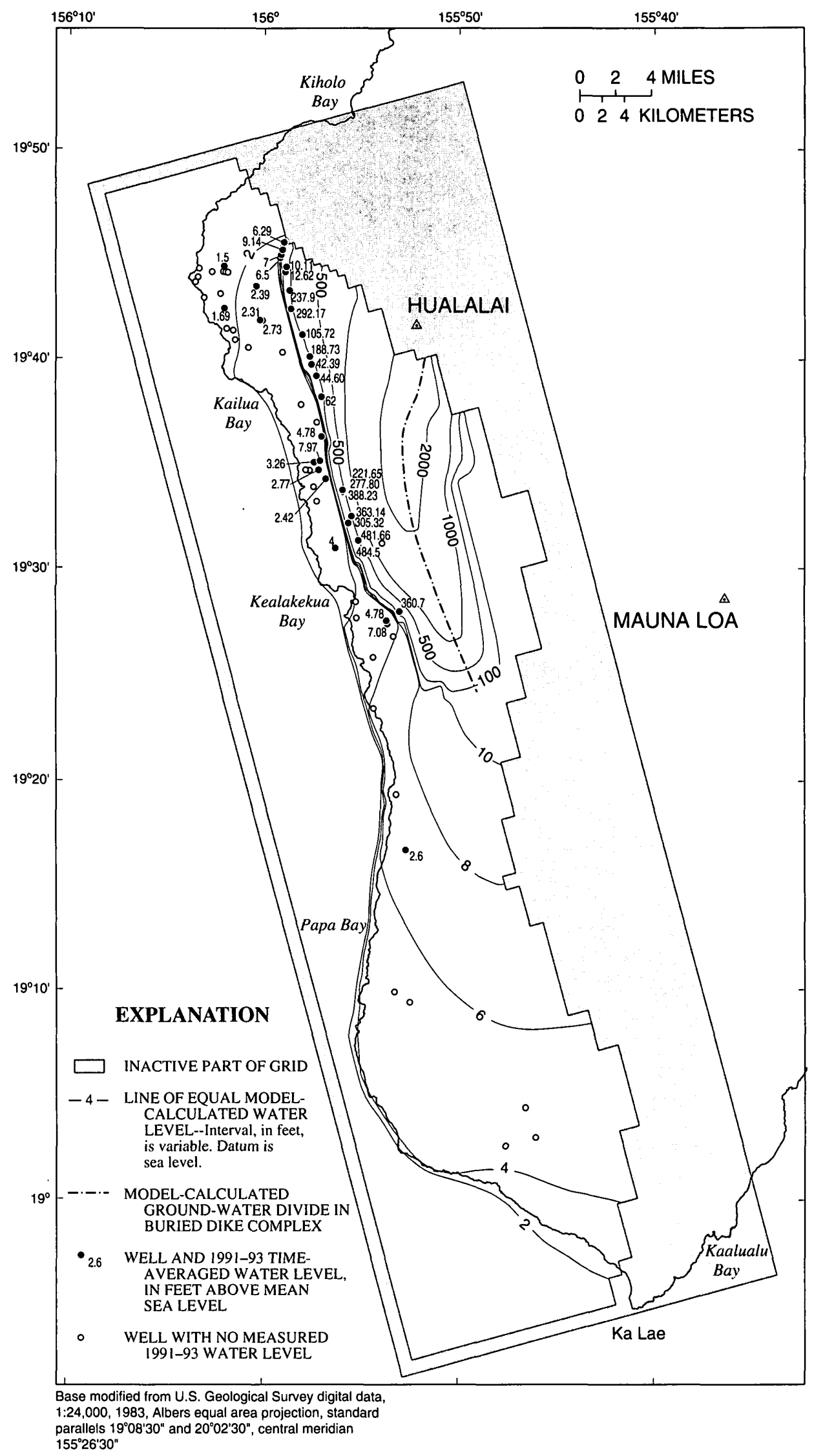

Figure 26. Model-calculated 1997 water levels for the Kona area, island of Hawaii. 
Table 7. Pumping rates used in model scenarios 1 through 3 , Kona area, island of Hawaii [Mgal/d, million gallons per day; --, data not available]

\begin{tabular}{|c|c|c|c|c|c|c|}
\hline Well number & $\begin{array}{l}\text { Altitude of top } \\
\text { of open interval } \\
\text { (feet) }\end{array}$ & $\begin{array}{c}\text { Altitude of } \\
\text { bottom of } \\
\text { open interval } \\
\text { (feet) }\end{array}$ & $\begin{array}{l}\text { Model cell } \\
\text { (row,column) }\end{array}$ & $\begin{array}{c}\text { Scenario } 1 \\
\text { pumping rate } \\
\text { (Mgal/d) }\end{array}$ & $\begin{array}{c}\text { Scenario } 2 \\
\text { pumping rate } \\
\text { (Mgal/d) }\end{array}$ & $\begin{array}{c}\text { Scenario } 3 \\
\text { pumping rate } \\
\text { (Mgal/d) }\end{array}$ \\
\hline \multicolumn{7}{|c|}{ Existing wells } \\
\hline $0952-01$ & 0 & -25 & 117,31 & 0.08 & 0.08 & 0.08 \\
\hline 0953-01 & -2 & -32 & 116,25 & 0.04 & 0.04 & 0.04 \\
\hline 2653-01 & -1 & -31 & 81,50 & 0.08 & 0.08 & 0.08 \\
\hline $2753-01$ & -26 & -36 & 80,50 & 0.12 & 0.12 & 0.12 \\
\hline $2753-02$ & 2 & -37 & 80,50 & 0.11 & 0.11 & 0.11 \\
\hline $2753-03$ & 364 & 4 & 79,52 & 0.48 & 0.48 & 0.48 \\
\hline $3155-02$ & 491 & 1 & 69,48 & 0.28 & 0.28 & 0.28 \\
\hline $3357-04$ & 2 & -18 & 64,44 & 0.33 & 0.33 & 0.33 \\
\hline $3457-01$ & 3 & -24 & 61,43 & 0.50 & 0.50 & 0.50 \\
\hline $3457-03$ & -1 & -21 & 61,44 & 0.17 & 0.17 & 0.17 \\
\hline $3557-01$ & -31 & -51 & 60,46 & 0.74 & 0.74 & 0.74 \\
\hline $3557-02$ & -30 & -42 & 61,46 & 0.87 & 0.87 & 0.87 \\
\hline $3557-03$ & 15 & -34 & 60,46 & 0.67 & 0.67 & 0.67 \\
\hline $3557-04$ & 3 & -50 & 61,46 & 0.22 & 0.22 & 0.22 \\
\hline $3557-05$ & -- & -5 & 60,45 & 4.73 & 4.73 & 4.73 \\
\hline $3657-01$ & -2 & -45 & 57,47 & 0.14 & 0.14 & 0.14 \\
\hline $4358-01$ & 69 & -51 & 29,48 & 0.42 & 0.42 & 0.42 \\
\hline $4363-01$ to -10 & -5 & -17 & 19,18 & 2.88 & 2.88 & 2.88 \\
\hline $4459-01$ & 0 & -84 & 19,48 & 0.00 & 0.00 & 0.00 \\
\hline $4459-02$ & -3 & -93 & 18,48 & 0.07 & 0.07 & 0.07 \\
\hline $4558-01$ & 4 & -79 & 15,49 & 0.10 & 0.10 & 0.10 \\
\hline $4559-01$ & 0 & -111 & 17,49 & 0.00 & 0.00 & 0.00 \\
\hline Total existing withdrawals & & & & 13.0 & 13.0 & 13.0 \\
\hline \multicolumn{7}{|c|}{ Proposed withdrawals } \\
\hline site 1 & 100 & -25 & 40,48 & 1.40 & 0.75 & 0.42 \\
\hline site $2(4158-02)$ & 100 & -60 & 42,48 & 1.40 & 0.75 & 0.42 \\
\hline site 3 & 100 & -25 & 44,48 & 1.00 & 0.75 & 0.42 \\
\hline site 4 & 100 & -25 & 45,48 & 1.00 & 0.75 & 0.42 \\
\hline site 5 & 100 & -25 & 46,48 & 1.00 & 0.75 & 0.42 \\
\hline site 6 including $4057-01$ & 100 & -25 & 48,49 & 3.65 & 0.75 & 0.42 \\
\hline site 7 & 100 & -25 & 49,48 & 2.65 & 0.75 & 0.42 \\
\hline site $8(3957-01)$ & 100 & -32 & 51,49 & 3.40 & 0.75 & 0.42 \\
\hline site 9 & 100 & -25 & 52,49 & 3.40 & 0.75 & 0.42 \\
\hline site 10 & 100 & -25 & 53,49 & 1.67 & 0.75 & 0.42 \\
\hline site 11 & 100 & -25 & 54,49 & 1.67 & 0.75 & 0.42 \\
\hline site 12 & 100 & -25 & 55,49 & 3.35 & 0.75 & 0.42 \\
\hline Total proposed withdrawals & & & & 25.6 & 9.0 & 5.0 \\
\hline
\end{tabular}

The top of the open interval for all proposed withdrawal wells (table 7) was assumed to be at an altitude of $100 \mathrm{ft}$. The bottom of the open interval was assumed to extend to the actual well depth for existing wells and to an altitude of $-25 \mathrm{ft}$ for proposed wells (table 7 ).

\section{Scenario 1--25.6 Mgal/d Proposed Withdrawal between Palani Junction and Holualoa}

In scenario 1 , a total withdrawal rate of 25.6 $\mathrm{Mgal} / \mathrm{d}$ (table 7) was initially simulated between Palani Junction and Holualoa in the high water-level area. Model results indicate that it may not be possible to withdraw $25.6 \mathrm{Mgal} / \mathrm{d}$ of freshwater from the high water-level area between Palani Junction and Holualoa, given the assumed well locations, well depths, and withdrawal rates. In the high water-level area, the water table was lowered below the bottoms of the wells in three model cells, including the cell with well 4057-01, and the model-calculated freshwater-saltwater interface was raised above the bottoms of the wells in six additional cells (table 8). The SHARP code sets the withdrawal rate to zero for the remainder of the simulation in cells in which the water table is lowered below the bottom of the well. In the model, the order in which withdrawals were set to zero in the three affected cells in scenario 1 was partly dependent on the assigned storage properties of the aquifer and the assumed initial 
Table 8. Model cells in which the water table is lowered below the bottom of simulated wells, and model-calculated rate of saltwater pumpage from cells in which the interface rises above the bottom of simulated wells, Kona, island of Hawaii [Mgal/d, million gallons per day]

\begin{tabular}{|c|c|c|c|c|}
\hline \multicolumn{2}{|c|}{$\begin{array}{l}\text { Cells in which the water table is } \\
\text { lowered below the bottom of the simulated wells }\end{array}$} & \multicolumn{3}{|c|}{$\begin{array}{l}\text { Cells in which the model-calculated interface } \\
\text { rises above the bottom of the simulated wells }\end{array}$} \\
\hline $\begin{array}{l}\text { Model cell } \\
\text { (row,column) }\end{array}$ & $\begin{array}{l}\text { Withdrawal rate lost } \\
\text { (Mgal/d) }\end{array}$ & $\begin{array}{l}\text { Model cell } \\
\text { (row,column) }\end{array}$ & $\begin{array}{c}\text { Freshwater } \\
\text { withdrawal rate } \\
\text { (MgaVd) }\end{array}$ & $\begin{array}{c}\text { Saltwater } \\
\text { withdrawal rate } \\
\text { (MgaVd) }\end{array}$ \\
\hline \multicolumn{5}{|c|}{ Scenario 1} \\
\hline 40,48 & 1.40 & 19,18 & 1.85 & 1.03 \\
\hline 48,49 & 3.65 & 42,48 & 0.91 & 0.49 \\
\hline \multirow[t]{5}{*}{52,49} & 3.40 & 45,48 & 0.00 & 1.00 \\
\hline & & 46,48 & 0.81 & 0.19 \\
\hline & & 51,49 & 0.00 & 3.40 \\
\hline & & 53,49 & 1.31 & 0.36 \\
\hline & & 55,49 & 3.10 & 0.25 \\
\hline \multicolumn{5}{|c|}{ Scenario 2} \\
\hline \multirow[t]{7}{*}{ none } & & 19,18 & 1.91 & 0.97 \\
\hline & & 40,48 & 0.63 & 0.12 \\
\hline & & 42,48 & 0.63 & 0.12 \\
\hline & & 44,48 & 0.51 & 0.24 \\
\hline & & 45,48 & 0.35 & 0.40 \\
\hline & & 46,48 & 0.69 & 0.06 \\
\hline & & 49,48 & 0.52 & 0.23 \\
\hline \multicolumn{5}{|c|}{ Scenario 3} \\
\hline none & & 19,18 & 2.02 & 0.86 \\
\hline
\end{tabular}

head distribution. For a different distribution of aquiferstorage properties or initial heads, the water table may have been lowered below the bottoms of wells in different cells. Thus, the steady-state head distribution simulated in scenario 1 was also partly dependent on the assigned aquifer-storage properties and assumed initial conditions.

In scenario $1,8.45 \mathrm{Mgal} / \mathrm{d}$ of the proposed 25.6 $\mathrm{Mgal} / \mathrm{d}$ withdrawal from the high water-level area was eliminated because the model-calculated water table was lowered below the simulated well bottoms. In addition, $5.69 \mathrm{Mgal} / \mathrm{d}$ of the remaining $17.1 \mathrm{Mgal} / \mathrm{d}$ was extracted from the saltwater zone below the modelcalculated freshwater-saltwater interface. (About 1.03 $\mathrm{Mgal} / \mathrm{d}$ was also withdrawn from below the modelcalculated freshwater-saltwater interface from wells 4363-01 to -10 near the coast.) Thus, in scenario 1 , only $11.5 \mathrm{Mgal} / \mathrm{d}$ of the desired $25.6 \mathrm{Mgal} / \mathrm{d}$ was withdrawn from the model-calculated freshwater zone in the high water-level area between Palani Junction and Holualoa.

For this study, the $0.01-\mathrm{ft}$ drawdown contour was arbitrarily chosen to represent the extent of drawdown. For a total model-calculated freshwater withdrawal rate of $11.5 \mathrm{Mgal} / \mathrm{d}$ in the high water-level area between Palani Junction and Holualoa, the model-calculated drawdown of $0.01 \mathrm{ft}$ or more extends about 9 mi northnorthwest of the proposed withdrawal sites, to the northernmost part of the study area, and about $10 \mathrm{mi}$ south of the proposed withdrawal sites, to within a mile of Kealakekua Bay (fig. 27). Drawdown was determined relative to steady-state water levels for average 1997 pumping conditions. Model-calculated drawdown is greatest in the high water-level area in the vicinity of the proposed withdrawal sites. Near well 4057-01 (proposed withdrawal site 6), however, model-calculated water levels are higher in scenario 1 than in the 1997 base case because of a reduction of withdrawal from the cell used to represent well 4057-01. For the 1997 basecase scenario, the withdrawal from well 4057-01 was $0.96 \mathrm{Mgal} / \mathrm{d}$, whereas in scenario 1, the final simulated withdrawal from the cell representing well 4057-01 was zero because the model-calculated water table was lowered below the simulated well bottom in this cell. Outside of the high water-level area, model-calculated drawdown is less than $1 \mathrm{ft}$.

For steady-state conditions, the rate of freshwater coastal discharge from the system will be reduced by an amount equal to the rate of additional freshwater withdrawal from the system. For 1997 conditions, the total model-calculated freshwater withdrawal rate was 13.3 $\mathrm{Mgal} / \mathrm{d}(14.0 \mathrm{Mgal} / \mathrm{d}$ total withdrawal minus $0.7 \mathrm{Mgal} / \mathrm{d}$ 


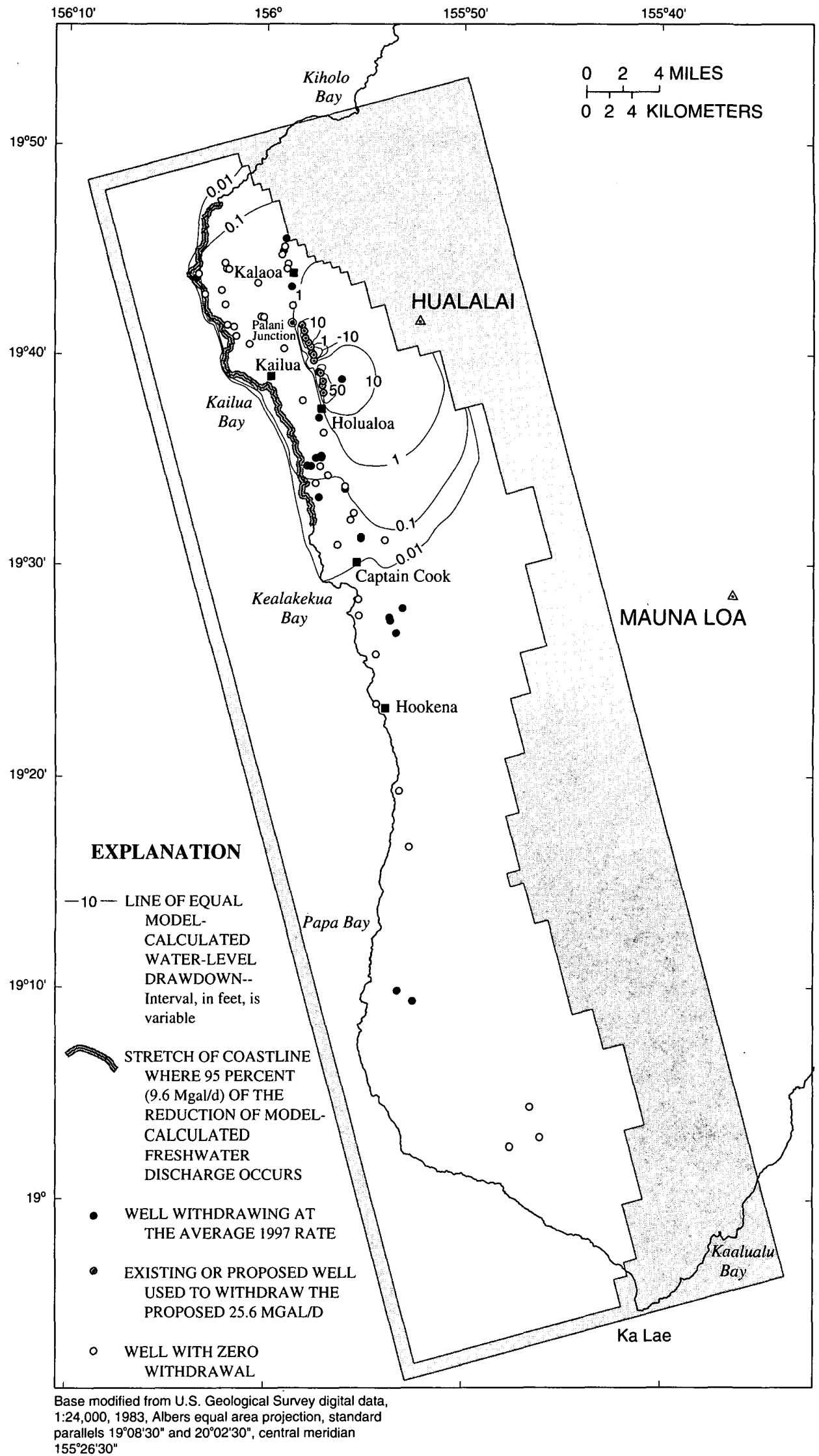

Figure 27. Model-calculated water-level drawdown and coastal-discharge reduction, relative to 1997 model-calculated conditions, caused by attempting to withdraw $25.6 \mathrm{Mgal} / \mathrm{d}$ from the high water-level area, Kona, island of Hawaii. Of the proposed $25.6 \mathrm{Mgal} / \mathrm{d}$ total withdrawal from the high water-level area between Palani Junction and Holualoa, 11.5 Mgal/d of freshwater was successfully withdrawn. 
saltwater withdrawal). In scenario 1 , the total modelcalculated freshwater withdrawal rate was about 23.4 $\mathrm{Mgai} / \mathrm{d}$ (30.1 Mgal/d total withdrawal minus 6.72 $\mathrm{Mgal} / \mathrm{d}$ saltwater withdrawal). The model-calculated freshwater withdrawal rate in scenario 1 represents an increase of $10.1 \mathrm{Mgal} / \mathrm{d}$ relative to the freshwater withdrawal rate for the 1997 base-case conditions. Thus, for steady-state conditions, the rate of model-calculated freshwater coastal discharge in scenario 1 is reduced by a total of $10.1 \mathrm{Mgal} / \mathrm{d}$ relative to the 1997 base case.

Model results indicate that the stretch of coastline where 95 percent $(9.6 \mathrm{Mgal} / \mathrm{d})$ of the total discharge reduction occurs extends for a distance of about $20 \mathrm{mi}$ along the western coast of the island (fig. 27). Along this 20-mi stretch of coastline, the rate of freshwater coastal discharge in the 1997 base case, without the additional withdrawal, is $52.3 \mathrm{Mgal} / \mathrm{d}$. For an additional freshwater withdrawal rate of $10.1 \mathrm{Mgal} / \mathrm{d}$, discharge along the delineated 20-mi stretch of coastline is reduced by 18 percent to $42.7 \mathrm{Mgal} / \mathrm{d}$.

\section{Scenario 2--9.0 Mgal/d Proposed Withdrawal between Palani Junction and Holualoa}

In scenario 2, a total proposed withdrawal rate of 9.0 Mgal/d was simulated between Palani Junction and Holualoa in the high water-level area (table 7). In this scenario, proposed withdrawals from the high waterlevel area between Palani Junction and Holualoa were arbitrarily distributed to the same 12 model cells (uniformly $0.75 \mathrm{Mgal} / \mathrm{d}$ per cell) used in scenario 1 (table 7).

Model results indicate that it may not be possible to withdraw $9.0 \mathrm{Mgal} / \mathrm{d}$ of freshwater from the high water-level area between Palani Junction and Holualoa, given the assumed well locations, well depths, and withdrawal rates. Although the water table was not lowered below the bottoms of the wells in any model cells, the model-calculated freshwater-saltwater interface was raised above the bottoms of the wells in six cells (table 8). In scenario 2, about $1.2 \mathrm{Mgal} / \mathrm{d}$ of the $9.0 \mathrm{Mgal} / \mathrm{d}$ proposed withdrawal was from below the model-calculated freshwater-saltwater interface, in the saltwater zone. (About $0.97 \mathrm{Mgal} / \mathrm{d}$ was also withdrawn from below the model-calculated freshwater-saltwater interface from wells 4363-01 to - 10 near the coast.) Thus, in scenario $2,7.8 \mathrm{Mgal} / \mathrm{d}$ of the desired $9.0 \mathrm{Mgal} / \mathrm{d}$ was withdrawn from the model-calculated freshwater zone in the high water-level area between Palani Junction and Holualoa.
For a total model-calculated freshwater withdrawal rate of $7.8 \mathrm{Mgal} / \mathrm{d}$ in the high water-level area between Palani Junction and Holualoa, the modelcalculated drawdown of $0.01 \mathrm{ft}$ or more extends about 9 mi north-northwest of the proposed withdrawal sites, to the northernmost part of the study area, and about $8 \mathrm{mi}$ south of the proposed withdrawal sites (fig. 28). The shapes of the lines of equal model-calculated drawdown in scenario 2 differ from those in scenario 1 because of the different distributions of freshwater and saltwater withdrawals simulated in the two scenarios. Modelcalculated drawdown is greatest in the high water-level area in the vicinity of proposed withdrawal sites. Near well 4057-01, however, model-calculated water levels are higher in scenario 2 than in the 1997 base case because of a reduction of withdrawal from the cell used to represent well 4057-01. Outside of the high waterlevel area, model-calculated drawdown is less than $1 \mathrm{ft}$.

For 1997 conditions, the total model-calculated freshwater withdrawal rate was $13.3 \mathrm{Mgal} / \mathrm{d}$ (14.0 $\mathrm{Mgal} / \mathrm{d}$ total withdrawal minus $0.7 \mathrm{Mgal} / \mathrm{d}$ saltwater withdrawal). In scenario 2 , the total model-calculated freshwater withdrawal rate was about $19.9 \mathrm{Mgal} / \mathrm{d}(22.0$ $\mathrm{Mgal} / \mathrm{d}$ total withdrawal minus $2.14 \mathrm{Mgal} / \mathrm{d}$ saltwater withdrawal). The model-calculated freshwater withdrawal rate in scenario 2 represents an increase of 6.6 $\mathrm{Mgal} / \mathrm{d}$ relative to the freshwater withdrawal rate for the 1997 base-case conditions. Thus, for steady-state conditions, the rate of model-calculated freshwater coastal discharge in scenario 2 is reduced by a total of 6.6 $\mathrm{Mgal} / \mathrm{d}$ relative to the 1997 base case.

Model results indicate that the stretch of coastline where 95 percent $(6.3 \mathrm{Mgal} / \mathrm{d})$ of the total discharge reduction occurs extends for a distance of about $20 \mathrm{mi}$ along the western coast of the island (fig. 28). Along this 20-mi stretch of coastline, the rate of freshwater coastal discharge in the 1997 base case, without the additional withdrawal, is $47.9 \mathrm{Mgal} / \mathrm{d}$. For an additional withdrawal rate of $6.6 \mathrm{Mgal} / \mathrm{d}$, discharge along the delineated 20 -mi stretch of coastline is reduced by 13 percent to $41.6 \mathrm{Mgal} / \mathrm{d}$.

\section{Scenario 3--5.0 Mgal/d Proposed Withdrawal between Palani Junction and Holualoa}

In scenario 3, a total withdrawal rate of $5.0 \mathrm{Mgal} / \mathrm{d}$ was simulated between Palani Junction and Holualoa in the high water-level area (table 7). This represents an increase of about $4.0 \mathrm{Mgal} / \mathrm{d}$ from average 1997 pumping conditions. In this scenario, proposed withdrawals 


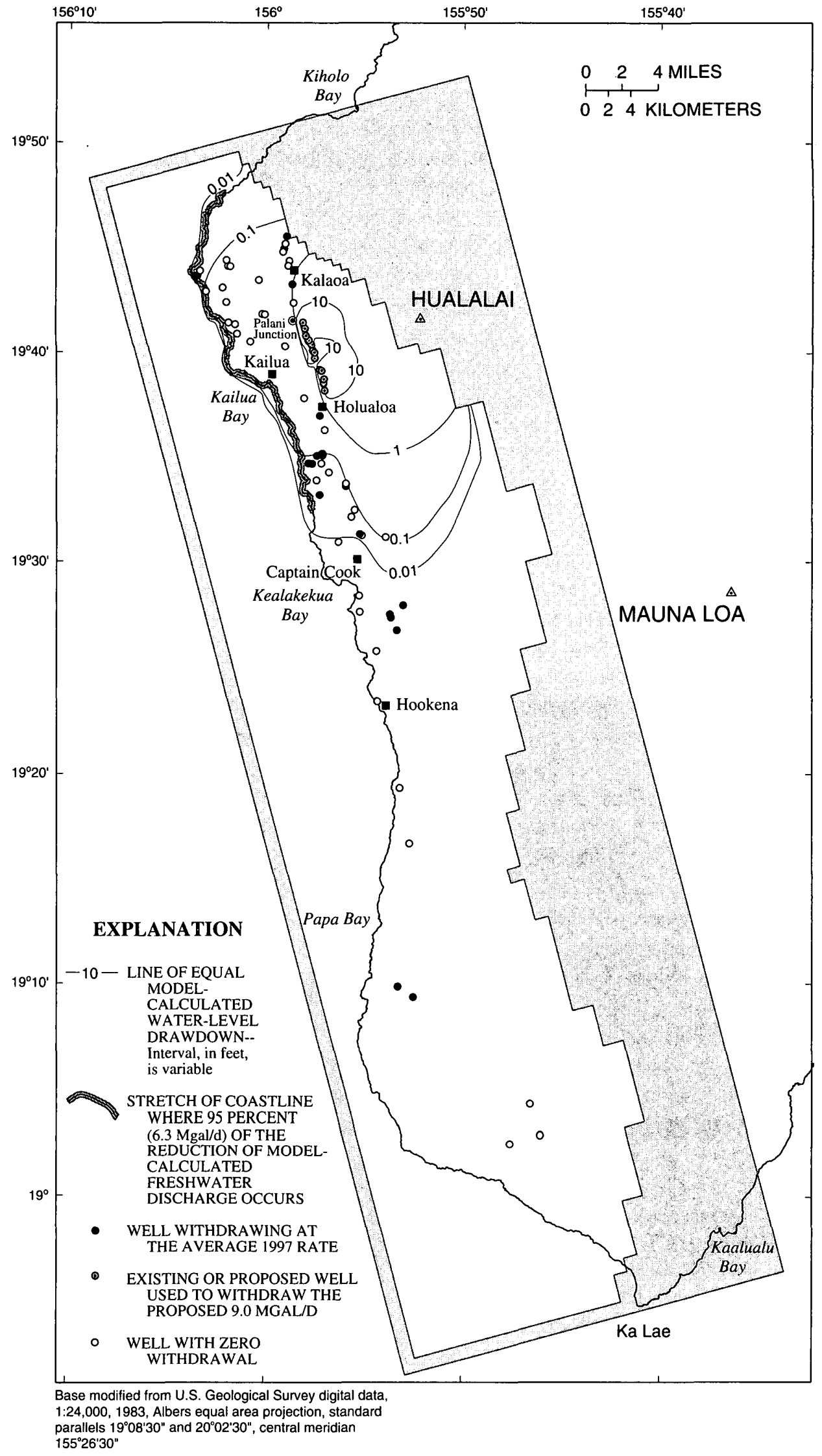

Figure 28. Model-calculated water-level drawdown and coastal-discharge reduction, relative to 1997 model-calculated conditions, caused by attempting to withdraw $9.0 \mathrm{Mgal} / \mathrm{d}$ from the high water-level area, Kona, island of Hawaii. Of the proposed $9.0 \mathrm{Mgal} / \mathrm{d}$ total withdrawal from the high water-level area between Palani Junction and Holualoa, $7.8 \mathrm{Mgal} / \mathrm{d}$ of freshwater was successfully withdrawn. 
from the high water-level area between Palani Junction and Holualoa were arbitrarily distributed to the same 12 model cells (uniformly $0.42 \mathrm{Mgal} / \mathrm{d}$ per cell) used in scenario 1 (table 7). To maintain this uniform distribution of proposed withdrawals in scenario 3 , the withdrawal rate from the cell containing well 4057-01 was reduced by $0.54 \mathrm{Mgal} / \mathrm{d}$ relative to average $1997 \mathrm{pump}$ ing conditions.

Model results indicate that for the assumed well locations, well depths, and pumping rates, it may be possible to withdraw $5.0 \mathrm{Mgal} / \mathrm{d}$ of freshwater from the high water-level area between Palani Junction and Holualoa. The water table was not lowered below the bottoms of the wells in any model cells, and the modelcalculated freshwater-saltwater interface was not raised above the bottoms of the wells in any cells in the high water-level area (table 8 ). (About $0.86 \mathrm{Mgal} / \mathrm{d}$ was, however, withdrawn from below the model-calculated freshwater-saltwater interface from wells 4363-01 to -10 near the coast.)

For a total model-calculated freshwater withdrawal rate of $5.0 \mathrm{Mgal} / \mathrm{d}$ in the high water-level area between Palani Junction and Holualoa, the modelcalculated drawdown of $0.01 \mathrm{ft}$ or more extends about 9 mi north-northwest of the proposed withdrawal sites, to the northernmost part of the study area, and about $7 \mathrm{mi}$ south of the proposed withdrawal sites (fig. 29). Modelcalculated drawdown is greatest in the high water-level area in the vicinity of the proposed withdrawal sites. Near well 4057-01, however, model-calculated water levels are higher in scenario 3 than in the 1997 base case because of a reduction of withdrawal from the cell used to represent well 4057-01. Outside the high water-level area, model-calculated drawdown is less than $1 \mathrm{ft}$.

In scenario 3, the total model-calculated freshwater withdrawal rate was about $17.1 \mathrm{Mgal} / \mathrm{d}$. The model-calculated freshwater withdrawal rate in scenario 3 represents an increase of $3.8 \mathrm{Mgal} / \mathrm{d}$ relative to the freshwater withdrawal rate for the 1997 base-case conditions. Thus, for steady-state conditions, the rate of model-calculated freshwater coastal discharge in scenario 3 is reduced by a total of $3.8 \mathrm{Mgal} / \mathrm{d}$ relative to the 1997 base case.

Model results indicate that the stretch of coastline where 95 percent $(3.6 \mathrm{Mgal} / \mathrm{d})$ of the total discharge reduction occurs extends for a distance of about $20 \mathrm{mi}$ along the western coast of the island (fig. 29). Along this 20-mi stretch of coastline, the rate of freshwater coastal discharge in the 1997 base case, without the additional withdrawal, is $47.3 \mathrm{Mgal} / \mathrm{d}$. For an additional withdrawal rate of $3.8 \mathrm{Mgal} / \mathrm{d}$, discharge along the delineated 20-mi stretch of coastline is reduced by 8 percent to $43.7 \mathrm{Mgal} / \mathrm{d}$.

\section{MODEL LIMITATIONS}

The steady-state ground-water flow model of the Kona area developed for this study has several limitations. Because available data are limited, the flow model is not considered to be calibrated. There are an insufficient number of monitoring wells to define the spatial distribution of water levels in the southwestern part of the island and the inland parts of the study area above a land-surface altitude of $2,000 \mathrm{ft}$. Thus, the distributions of model-calculated water levels and freshwater-saltwater interface altitudes, although informative, are unverified in places.

The model developed for this study is not unique. That is, it is possible that different distributions of hydraulic conductivity, coastal leakance, and aquifer thickness can be used in a model to produce equally acceptable model-calculated water levels. Model zones were created to represent marginal dike zones. Although this zonation is plausible, it is probable that other zonation geometries could produce similar results. The number of model zones was minimized because of the limited data. The model developed for this study can be refined and a better representation of the flow system can be obtained as more data become available to constrain the model.

Although the overall distribution of model-calculated water levels in the high water-level area is in general agreement with measured water levels, the absolute difference between model-calculated and measured water levels at a specific site is as much as $230 \mathrm{ft}$. Note, however, that the measured water levels in two wells located only $800 \mathrm{ft}$ apart in the high water-level area can differ by $160 \mathrm{ft}$. The regional model may not accurately simulate the high water levels in the compartmentalized part of the aquifer because local-scale geologic conditions and vertical head gradients are not represented in the model.

The recharge estimates developed in this study were made using an annual water budget. It is recognized that there may be significant uncertainty associated with the recharge estimates. The results of the 


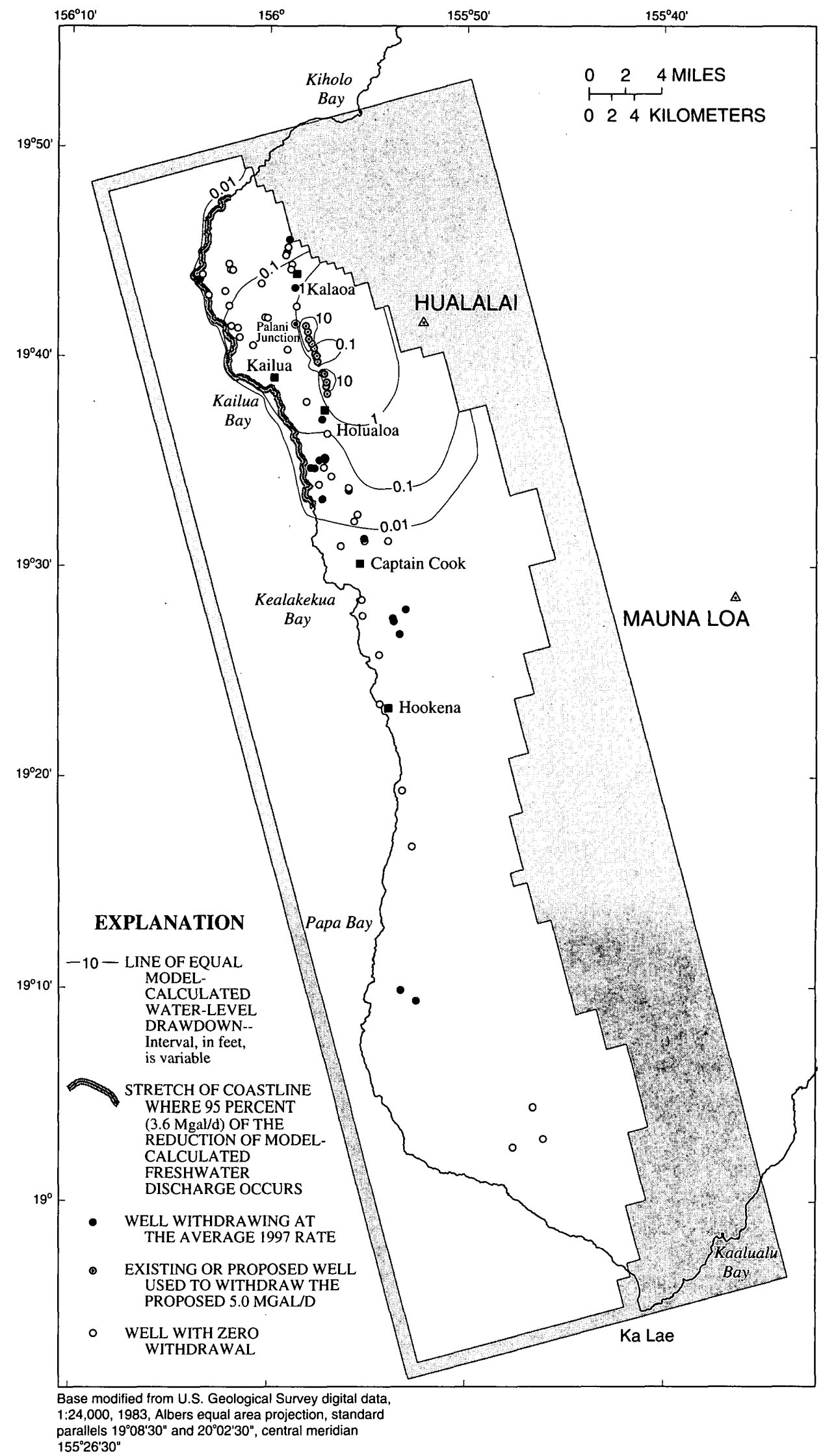

Figure 29. Model-calculated water-level drawdown and coastal-discharge reduction, relative to 1997 model-calculated conditions, caused by withdrawing $5.0 \mathrm{Mgal} / \mathrm{d}$ from the high water-level area between Palani Junction and Holualoa, Kona, island of Hawaii. 
ground-water flow model are limited by this uncertainty.

The ground-water flow model cannot accurately predict the local drawdown in a pumped well because of the discrete nature of the finite-difference approach. Simulated drawdown at a given location in a model cell is represented by the average drawdown for the entire cell. Because the ground-water flow model contains only a single layer, vertical head gradients cannot be simulated and model-calculated drawdown caused by additional withdrawals may underestimate actual drawdown near partially penetrating wells. However, it also is possible that the model may overestimate drawdown where local geologic conditions are not well represented in the regional model. For example, the regional model assumes a homogeneous, isotropic horizontal hydraulic conductivity for the buried dike complex. The actual hydraulic conductivity in areas with dikes may vary significantly from the simplified representation in the single-layered model. Furthermore, the assumed location of the aquifer bottom may not accurately represent the actual aquifer bottom, and this could lead to errors in the estimated hydraulic-conductivity distribution, particularly for the buried dike-complex zone and marginal dike zones. The model developed for this study simulates regional water levels, but the model should not be viewed as a quantitatively accurate predictive tool to simulate local-scale water-level drawdown because of the uncertainty in the model hydraulicconductivity distribution. The model is, nevertheless, the best available tool for predicting the possible regional hydrologic effects of additional withdrawals in the Kona area for steady-state conditions.

The model developed for this study cannot predict the distribution of salinity within the aquifer and is not capable of predicting the quality of water pumped from a given well. Because of mixing effects, a diffuse transition zone exists near the coastal parts of the study area. Furthermore, available data indicate that brackish water exists immediately below the water table in some areas. The regional model developed for this study assumes that freshwater and saltwater do not mix. The model simulates the location of the freshwater-saltwater interface but cannot be used to simulate local upconing in the vicinity of pumped wells.

Because the model was not calibrated for transient conditions, it cannot be used to predict time-varying water levels or coastal discharges. Thus, following a change in withdrawal or recharge rates, the amount of time for water-level and coastal-discharge changes to occur cannot be predicted using the model developed for this study.

\section{DATA NEEDS}

Additional data are needed to improve the understanding of the ground-water flow system in the Kona area of western Hawaii. As more data become available, the ground-water flow model developed for this study can be refined and the accuracy of model-predictions can thereby be improved. A few specific data needs are briefly described below.

1. Wider spatial and longer temporal distributions of water levels are needed to define directions of ground-water flow and to characterize the hydrologic effects of changes in recharge or withdrawals from the ground-water system. Information on the vertical distribution of water levels would also help to refine the conceptual model of the groundwater flow system. Additional water-level data also are needed to calibrate a ground-water flow model.

2. More information is needed to better understand the subsurface geology, which is an important control on the horizontal and vertical distributions of water levels and the rates and directions of ground-water flow. Additional information related to the subsurface geology also could improve the understanding and representation of the groundwater flow system in the interior, high-altitude areas, and at depth throughout the study area.

3. Aquifer-test data are needed to obtain independent estimates of the horizontal and vertical hydraulic-conductivity distributions throughout the study area. These independent estimates can serve as a check of the hydraulic-conductivity estimates obtained using a numerical groundwater flow model.

4. Improved recharge estimates can lead to enhanced confidence in ground-water flow-model predictions.

5. Deep monitor wells are needed to define the vertical distribution of salinity in ground water. Data from these wells are essential to estimate the availability of fresh ground water. 


\section{SUMMARY AND CONCLUSIONS}

The island of Hawaii is formed primarily by the shield-stage lavas of Mauna Loa and Kilauea and the shield- and postshield-stage lavas of Kohala, Hualalai, and Mauna Kea. Lavas from Mauna Loa and Hualalai cover the Kona study area, which includes the southern and northwestern parts of Hualalai and the western part of Mauna Loa. Hualalai, which last erupted in 1801, rises to an altitude of $8,271 \mathrm{ft}$. Mauna Loa last erupted in 1984 and rises to an altitude of 13,679 ft. The slopes of Hualalai and Mauna Loa are generally smooth, except where shallow stream courses have formed or where cinder cones or faults exist.

The rift zones of Mauna Loa and Hualalai are marked by cinder and spatter cones and fissure vents. Unexposed dikes also are associated with the rift zones. The rift zones are hydrologically important because dikes in the rift zones have low permeability and tend to impede the flow of ground water. The rift zones of Mauna Loa and Hualalai were used to define the boundaries of the study area. Hydrologic and geophysical data indicate that a buried Hualalai rift zone, trending approximately south and parallel to the coast, may exist within the study area. This geologic feature may explain the presence of high water levels (greater than $40 \mathrm{ft}$ above sea level) in the Kona area.

In the Kona area, ground-water recharge from infiltration of rainfall is enhanced by intercepted cloud vapor that precipitates as fog drip. Fog develops predominantly in the afternoon hours of the day and can be intercepted by vegetation and the ground surface. Ground-water recharge in the study area was estimated using an annual water budget to be $357.5 \mathrm{Mgal} / \mathrm{d}$. Of this total, it is estimated that fog drip accounts for about $63 \mathrm{Mgal} / \mathrm{d}$.

Fresh ground water in the Kona area is found in two main forms: (1) as a lens-shaped body of freshwater, called a freshwater lens, floating on denser, underlying saltwater within permeable lava flows near the coast, and (2) as water impounded to high levels (greater than $40 \mathrm{ft}$ above sea level) within the inland part of the aquifer with lower overall permeability. Fresh ground water flows from the high water-level area to the downgradient freshwater lens, where water levels are generally less than $10 \mathrm{ft}$ above sea level.

Most of the fresh ground water withdrawn is from the area north of Honaunau, from the lens of freshwater near the coast. A smaller amount of water is withdrawn from the high water-level area, inland of the freshwater lens. The total reported annual mean pumpage for the Kona area during 1997 was $11.1 \mathrm{Mgal} / \mathrm{d}$. An additional estimated $2.9 \mathrm{Mgal} / \mathrm{d}$ of saline water was withdrawn from the Kona area, near Keahole. Of the reported 11.1 $\mathrm{Mgal} / \mathrm{d}$ withdrawn in $1997,9.8 \mathrm{Mgal} / \mathrm{d}$ was withdrawn by the County of Hawaii Department of Water Supply (DWS).

Measured water levels are available primarily at wells within about $5 \mathrm{mi}$ of the coast. For wells located less than about $3 \mathrm{mi}$ from the coast, measured water levels are typically less than $10 \mathrm{ft}$ above sea level in the highly permeable part of the aquifer that is not intruded by dikes. Measured water levels in the dike-free volcanic rocks generally increase in an inland direction at the rate of about a foot per mile.

High water levels exist inland of the freshwater lens. Of the wells drilled in the high water-level area prior to May 1998, Kainaliu well 3255-02 is located nearest to the coast, at a distance of about $2 \mathrm{mi}$ inland. Measured water levels in the high water-level area are generally between about 40 and $500 \mathrm{ft}$ above sea level. As of May 1998, only one well has a measured water level greater than $500 \mathrm{ft}$.

Water-level records for wells in the dike-free volcanic rocks seaward of the high water-level area do not show any consistent trend during 1991-97. However, water levels measured in several wells in the high water-level area show a slight downward trend from 1993 to 1996.

Chloride concentration is generally used as an indicator of saltwater intrusion into the ground-water system. In general, chloride concentrations in the aquifer are expected to increase with depth and proximity to the ocean. Chloride concentrations of water samples from wells are less than $20 \mathrm{mg} / \mathrm{L}$ in the high water-level area and range from less than $10 \mathrm{mg} / \mathrm{L}$ to more than $1,000 \mathrm{mg} / \mathrm{L}$ seaward of the high water-level area. Chloride concentrations of pumped water from two county wells (2753-02 and 3557-05) have exceeded $250 \mathrm{mg} / \mathrm{L}$ in recent years. Chloride concentrations of pumped water from wells seaward of the high water-level area have increased as pumping rates have increased.

A two-dimensional (areal), sharp-interface ground-water flow model using the computer code SHARP (Essaid, 1990) was developed to simulate steady-state ground-water flow in the Kona area. 
For modeling purposes, the Kona study area was divided into four horizontal hydraulic-conductivity zones: (1) dike-free volcanic rocks, (2) buried Hualalai dike complex, (3) northern marginal dike zone (north of Kalaoa) where measured water levels range from about 6 to $13 \mathrm{ft}$, and (4) southern marginal dike zone inland of Kailua, between Palani Junction and Holualoa, where measured water levels range from about 40 to $190 \mathrm{ft}$. The buried Hualalai dike-complex zone was modeled as a zone of lower overall hydraulic conductivity relative to the dike-free volcanic-rocks zone. On the basis of measured water levels, model zones were created for locations where marginal dike zones are presumed to exist. The hydraulic conductivity of the marginal dike zones lies between the values for the dike-free volcanic rocks and the buried Hualalai dike complex.

To estimate the hydraulic-conductivity values for the model zones, average recharge, withdrawals, and water-level conditions for the period 1991-93 were simulated. Ground-water withdrawals in the Kona area during the period 1991-93 averaged $13.6 \mathrm{Mgal} / \mathrm{d}$, and average annual recharge was estimated to be 357.5 $\mathrm{Mgal} / \mathrm{d}$. The following horizontal hydraulic-conductivity values were estimated: (1) 7,500 ft/d for the dikefree volcanic rocks of Hualalai and Mauna Loa, (2) 0.1 $\mathrm{ft} / \mathrm{d}$ for the buried Hualalai dike complex, (3) $10 \mathrm{ft} / \mathrm{d}$ for the northern marginal dike zone, and (4) $0.5 \mathrm{ft} / \mathrm{d}$ for the southern marginal dike zone. The coastal leakance was estimated to be $0.05 \mathrm{ft} / \mathrm{d} / \mathrm{ft}$.

The spatial distribution of model-calculated water levels are in general agreement with the limited set of measured water levels. Model results indicate, however, that water levels do not strictly increase in an inland direction and that a ground-water divide exists within the buried dike complex. Data are not available, however, to verify model results in the area near the model-calculated ground-water divide.

Using the average recharge estimate of 357.5 $\mathrm{Mgal} / \mathrm{d}$ and the final hydraulic characteristics estimated from the model simulations for the 1991-93 period, water levels and discharges for a 1997 base-case scenario were simulated. In the high water-level area, model-calculated steady-state water levels for average 1997 withdrawal rates are lower than the model-calculated steady-state water levels for 1991-93 withdrawal rates by as much as $85 \mathrm{ft}$. The general decrease in water levels in the high water-level area can be attributed to an increase in ground-water withdrawals from the high water-level area, from $0.0 \mathrm{Mgal} / \mathrm{d}$ during 1991-93, to 2.1 Mgal/d in 1997.

Outside of the high water-level area, model-calculated steady-state water levels generally decreased by less than $0.1 \mathrm{ft}$ from 1991-93 conditions to 1997 conditions. For 1997 conditions, total ground-water withdrawal represented in the model was $14.0 \mathrm{Mgal} / \mathrm{d}$. The model predicts that $13.3 \mathrm{Mgal} / \mathrm{d}$ is withdrawn from the freshwater zone and $0.7 \mathrm{Mgal} / \mathrm{d}$ is withdrawn from the saltwater zone.

To estimate the hydrologic effects, relative to the 1997 base-case scenario, of withdrawing additional ground water, three scenarios were simulated. In all three scenarios, average annual recharge of 357.5 $\mathrm{Mgal} / \mathrm{d}$ was used. In scenarios 1,2 , and 3, proposed withdrawal rates of $25.6,9.0$, and $5.0 \mathrm{Mgal} / \mathrm{d}$, respectively, were simulated in the high water-level area between Palani Junction and Holualoa. In scenario 1, proposed withdrawals from the high water-level area between Palani Junction and Holualoa were nonuniformly distributed to 12 model cells according to the North Kona Water Master Plan (State of Hawaii, 1995). In scenarios 2 and 3, proposed withdrawals were uniformly distributed to the same 12 model cells used in scenario 1.

Scenario 1.--Model results from scenario 1 indicate that it may not be possible to withdraw $25.6 \mathrm{Mgal} / \mathrm{d}$ of freshwater from the high water-level area between Palani Junction and Holualoa, given the assumed well locations, well depths, and withdrawal rates. In the high water-level area, the water table was lowered below the bottoms of the wells in three model cells, and the model-calculated freshwater-saltwater interface was raised above the bottoms of the wells in six additional cells. In scenario 1 , only $11.5 \mathrm{Mgal} / \mathrm{d}$ of the desired 25.6 $\mathrm{Mgal} / \mathrm{d}$ was withdrawn from the model-calculated freshwater zone in the high water-level area between Palani Junction and Holualoa.

For a total model-calculated freshwater withdrawal rate of $11.5 \mathrm{Mgal} / \mathrm{d}$ in the high water-level area between Palani Junction and Holualoa, the modelcalculated drawdown of $0.01 \mathrm{ft}$ or more extends about 9 mi north-northwest of the proposed withdrawal sites, to the northernmost part of the study area, and about $10 \mathrm{mi}$ south of the proposed withdrawal sites, near Captain Cook. Drawdown was estimated relative to steady-state water levels for average 1997 pumping conditions. Model-calculated drawdown is greatest in the high 
water-level area in the vicinity of the proposed withdrawal sites. Outside of the high water-level area, model-calculated drawdown is less than $1 \mathrm{ft}$.

For steady-state conditions, the rate of freshwater coastal discharge in scenario 1 is reduced by a total of 10.1 Mgal/d relative to the 1997 base case. Model results indicate that the stretch of coastline where 95 percent $(9.6 \mathrm{Mgal} / \mathrm{d})$ of the total discharge reduction occurs extends for a distance of about $20 \mathrm{mi}$ along the western coast of the island.

Scenario 2.--Model results from scenario 2 indicate that it may not be possible to withdraw $9.0 \mathrm{Mgal} / \mathrm{d}$ of freshwater from the high water-level area between Palani Junction and Holualoa, given the assumed well locations, well depths, and withdrawal rates. Although the water table was not lowered below the bottoms of the wells in any model cells, the model-calculated freshwater-saltwater interface was raised above the bottoms of the wells in six cells. In scenario 2 , only $7.8 \mathrm{Mgal} / \mathrm{d}$ of the desired $9.0 \mathrm{Mgal} / \mathrm{d}$ was withdrawn from the model-calculated freshwater zone in the high waterlevel area between Palani Junction and Holualoa.

For a total model-calculated freshwater withdrawal rate of $7.8 \mathrm{Mgal} / \mathrm{d}$ in the high water-level area between Palani Junction and Holualoa, the modelcalculated drawdown of $0.01 \mathrm{ft}$ or more extends about 9 mi north-northwest of the proposed withdrawal sites, to the northernmost part of the study area, and about $8 \mathrm{mi}$ south of the proposed withdrawal sites. Model-calculated drawdown is greatest in the high water-level area in the vicinity of the proposed withdrawal sites. Outside of the high water-level area, model-calculated drawdown is less than $1 \mathrm{ft}$.

For steady-state conditions, the rate of freshwater coastal discharge in scenario 2 is reduced by a total of 6.6 Mgal/d relative to the 1997 base case. Model results indicate that the stretch of coastline where 95 percent (6.3 Mgal/d) of the total discharge reduction occurs extends for a distance of about $20 \mathrm{mi}$ along the western coast of the island.

Scenario 3.--Model results indicate that for the assumed well locations, well depths, and pumping rates used in scenario 3, it may be possible to withdraw 5.0 $\mathrm{Mgal} / \mathrm{d}$ of freshwater from the high water-level area between Palani Junction and Holualoa. In the high water-level area, the water table was not lowered below the bottoms of the wells in any model cells, and the model-calculated freshwater-saltwater interface was not raised above the bottoms of the wells in any cells.

For a total model-calculated freshwater withdrawal rate of $5.0 \mathrm{Mgal} / \mathrm{d}$ in the high water-level area between Palani Junction and Holualoa, the modelcalculated drawdown of $0.01 \mathrm{ft}$ or more extends about 9 mi north-northwest of the proposed withdrawal sites, to the northernmost part of the study area, and about $7 \mathrm{mi}$ south of the proposed withdrawal sites. Model-calculated drawdown is greatest in the high water-level area in the vicinity of the proposed withdrawals. Outside of the high water-level area, model-calculated drawdown is less than $1 \mathrm{ft}$.

For steady-state conditions, the rate of freshwater coastal discharge in scenario 3 is reduced by a total of $3.8 \mathrm{Mgal} / \mathrm{d}$ relative to the 1997 base case. Model results indicate that the stretch of coastline where 95 percent (3.6 Mgal/d) of the total discharge reduction occurs extends for a distance of about $20 \mathrm{mi}$ along the western coast of the island.

The model developed for this study tested a limited number of proposed withdrawal scenarios and was not used to optimize ground-water withdrawals from the high water-level area. It is likely that with optimal well siting and pumping rates, ground water can be withdrawn at rates greater than indicated by the scenarios tested.

The ground-water flow model of the Kona area developed for this study has several limitations. The most significant limitation is that, because of a lack of sufficient water-level data, the ground-water flow model is not considered to be calibrated and furthermore, is not unique.

As more data become available, the ground-water flow model developed for this study can be refined and the accuracy of model predictions can be improved. Additional data needed to improve the understanding of the ground-water flow system in the Kona area include: (1) a wider spatial distribution and longer periods of measurement of water levels, (2) improved information about the subsurface geology, (3) independent estimates of hydraulic conductivity, (4) improved recharge estimates, and (5) information about the vertical distribution of water levels and salinity. 


\section{REFERENCES CITED}

Adams, W.M., Peterson, F.L., Mathur, S.P., Lepley, L.K., Warren, Clifton, and Huber, R.D., 1969, A hydrogeophysical survey from Kawaihae to Kailua-Kona, Hawaii: Honolulu, Hawaii, University of Hawaii Water Resources Research Center Technical Report no. 32, $156 \mathrm{p}$.

Bean, Christine, Juvik, J.O., and Nullet, Dennis, 1994, Mountain evaporation profiles on the island of Hawai' $i$ : Journal of Hydrology, v. 156, nos. 1-4, p. 181-192.

Blackhawk Geosciences, Inc., 1991, Geophysical surveys for characterizing the hydrogeologic regime in the vicinity of Kealakehe, Hawaii: Report to Department of Land and Natural Resources, State of Hawaii, June 11, 1991, 12 p. + app.

Blumenstock, D.I., and Price, Saul, 1967, Climate of Hawaii, in Climates of the States, no. 60-51, Climatography of the United States: U.S. Department of Commerce.

Chinn, S.S., Tateishi, G.A., and Yee, J.J.S., 1983, Water resources data, Hawaii and other Pacific areas, water year 1982, Volume 1. Hawaii: U.S. Geological Survey Water-Data Report HI-82-1, 243 p.

Clague, D.A., 1982, Petrology of tholeiitic basalt dredged from Hualalai Volcano, Hawaii [abs.]: Eos, American Geophysical Union Transactions, v. 63, p. 1138.

Clague, D.A., 1987, Hawaiian xenolith populations, magma supply rates, and development of magma chambers: Bulletin of Volcanology, v. 49, p. 577-587.

Cooper, H.H., Jr., Kohout, F.A., Henry, H.R., and Glover, R.E., 1964, Sea water in coastal aquifers: U.S. Geological Survey Water-Supply Paper 1613-C, 84 p.

Davis, D.A., and Yamanaga, George, 1968, Preliminary report on the water resources of the Kona area, Hawaii: State of Hawaii, Department of Land and Natural Resources, Circular C46, $22 \mathrm{p}$.

Domenico, P.A., and Schwartz, F.W., 1990, Physical and chemical hydrogeology: New York, John Wiley \& Sons, Inc., $824 \mathrm{p}$.

Dorman, C.E., and Bourke, R.H., 1979, Precipitation over the Pacific Ocean, $30^{\circ} \mathrm{S}$ to $60^{\circ} \mathrm{N}$ : Monthly Weather Review, v. 107 , no. 7, p. 896-910.

Ekern, P.C., and Chang, J.-H., 1985, Pan evaporation: State of Hawai 'i, 1894-1983: State of Hawaii, Department of Land and Natural Resources, Report R74, $172 \mathrm{p}$.

Elliot, W.P., and Reed, R.K., 1984, A climatological estimate of precipitation for the world ocean: Journal of Applied Meteorology, v. 23, no. 3, p. 434-439.

Essaid, H.I., 1990, The computer model SHARP, a quasithree-dimensional finite-difference model to simulate freshwater and saltwater flow in layered coastal aquifer systems: U.S. Geological Survey Water-Resources Investigations Report 90-4130, $181 \mathrm{p}$.

Fischer, W.A., Davis, D.A., and Sousa, T.M., 1966, Freshwater springs of Hawaii from infrared images: U.S. Geological Survey Hydrologic Investigations Atlas HA-218.

Ferris, J.G., Knowles, D.B., Brown, R.H., and Stallman, R.W., 1962, Theory of aquifer tests: U.S. Geological Survey Water-Supply Paper 1536-E, 174 p.

Fontaine, R.A., 1996, Evaluation of the surface-water quantity, surface-water quality, and rainfall data-collection programs in Hawaii, 1994: U.S. Geological Survey Water-Resources Investigations Report 95-4212, $125 \mathrm{p}$.

Fornari, D.J., Lockwood, J.P., Lipman, P.W., Rawson, Michael, and Malahoff Alexander, 1980, Submarine volcanic features west of Kealakekua Bay, Hawaii: Journal of Volcanology and Geothermal Research, v. 7, no. 3/4, p. 323-337.

Funkhouser, J.G., Barnes, I.L., and Naughton, J.J., 1968, The determination of a series of ages of Hawaiian volcanoes by the potassium-argon method: Pacific Science, v. 22, no. 3, p. 369-372.

Giambelluca, T.W., 1983, Water balance of the Pearl HarborHonolulu basin, Hawai' $i$, 1946-1975: University of Hawaii Water Resources Research Center Technical Report no. 151, $151 \mathrm{p}$.

Giambelluca, T.W., and Nullet, Dennis, 1991, Influence of the trade-wind inversion on the climate of a leeward mountain slope in Hawaii: Climate Research, v. 1, p. 207-216.

Giambelluca, T.W., and Nullet, Dennis, 1992, Evaporation at high elevations: Journal of Hydrology, v. 136, nos. 1-4, p. 219-235.

Giambelluca, T.W., Nullet, M.A., and Schroeder, T.A., 1986, Rainfall atlas of Hawai ' $i$ : State of Hawaii, Department of Land and Natural Resources, Report R76, 267 p.

Giambelluca, Tom., and Sanderson, Marie, 1993, The water balance and climatic classification, chap. 4 of Sanderson, Marie, ed., Prevailing trade winds: Honolulu, Hawaii, University of Hawaii Press, p. 56-72.

Hildenbrand, T.G., Rosenbaum, J.G., and Kauahikaua, Jim, 1993, Aeromagnetic study of the island of Hawaii: Journal of Geophysical Research, v. 98, no. B3, p. 4,0994,119 .

Hill, D.P., and Zucca, J.J., 1987, Geophysical constraints on the structure of Kilauea and Mauna Loa Volcanoes and some implications for seismomagmatic processes, chap. 37 of Decker, R.W., Wright, T.L., and Stauffer, P.H., eds., Volcanism in Hawaii: U.S. Geological Survey Professional Paper 1350, v. 2, p. 903-917.

Jacobi, J.D., 1989, Vegetation maps of the upland plant communities on the islands of Hawai' $i$, Maui, Moloka' $i$, and 
Lana 'i: Honolulu, Hawaii, University of Hawaii, Department of Botany Technical Report no. 68, 25 p.

Juvik, J.O., and Ekern, P.C., 1978, A climatology of mountain fog on Mauna Loa, Hawai' $i$ island: Honolulu, Hawaii, University of Hawaii Water Resources Research Center Technical Report no. 118, 63 p.

Juvik, J.O., Singleton, D.C., and Clarke, G.G., 1978, Climate and water balance on the island of Hawaii, in Miller, John, ed., Mauna Loa Observatory, Twentieth Anniversary Report, U.S. Department of Commerce, National Oceanic and Atmospheric Administration Environmental Research Laboratory, p. 129-139.

Juvik, J.O., and Nullet, Dennis, 1995, Relationships between rainfall, cloud-water interception, and canopy throughfall in a Hawaiian montane forest, chap. 11 of Hamilton, L.S., Juvik, J.O., and Scatena, F.N., eds., Tropical Montane Cloud Forests: New York, Springer-Verlag, p. 165182.

Kanehiro, B.Y., and Peterson, F.L., 1977, Groundwater recharge and coastal discharge for the northwest coast of the island of Hawai ' $\mathrm{i}$ : A computerized water budget approach: Honolulu, Hawaii, University of Hawaii Water Resources Research Center Technical Report no. $110,83 \mathrm{p}$.

Kauahikaua, Jim, 1993, A west Mauna Loa structure revealed by static groundwater levels and geophysical evidence, Hawai' $i$ [abs.]: Eos, American Geophysical Union Transactions, supplement October 26, 1993.

Kauahikaua, Jim, Takasaki, Kiyoshi, and Jackson, D.B., 1985, An evaluation of ground-water resources in Kailua-Kona, Hawai ' $i$ using electric geophysical measurements: U.S. Geological Survey Open-File-Report 85-33, $21 \mathrm{p}$.

Kauahikaua, Jim, Duarte, Ka'eo, and Foster, James, 1998, A preliminary gravity survey of the Kailua-Kona area, Hawai ' $i$, for delineation of a hydrologic boundary: U.S. Geological Survey Open-File Report 98-110, 15 p.

Kimble, Howard, 1915, Report of the north and south Kona, Hawaii water investigation: Division of Hydrography, Bureau of Agriculture and Forestry, $34 \mathrm{p}$.

Kinoshita, W.T., 1965, A gravity survey of the island of Hawaii: Pacific Science, v. 19, no. 3, p. 339-340.

Kinoshita, W.T., Krivoy, H.L., Mabey, D.R., and Macdonald, R.R., 1963, Gravity survey of the island of Hawaii: U.S. Geological Survey Professional Paper 475-C, p. C114C116.

Langenheim, V.A.M., and Clague, D.A., 1987, The Hawaiian-Emperor volcanic chain, part II, stratigraphic framework of volcanic rocks of the Hawaiian Islands, chap. 1 of Decker, R.W., Wright, T.L., and Stauffer, P.H., eds., Volcanism in Hawaii: U.S. Geological Survey Professional Paper 1350, v. 1, p. 55-84.
Lipman, P.W., Normark, W.R., Moore, J.G., Wilson, J.B., and Gutmacher, C.E., 1988, The giant submarine Alika debris slide, Mauna Loa, Hawaii: Journal of Geophysical Research, v. 93, no. B5, p. 4279-4299.

Lockwood, J.P., and Lipman, P.W., 1987, Holocene eruptive history of Mauna Loa Volcano, chap. 18 of Decker, R.W., Wright, T.L., and Stauffer, P.H., eds., Volcanism in Hawaii: U.S. Geological Survey Professional Paper 1350 , v. 1, p. 509-535.

Macdonald, G.A., Abbott, A.T., and Peterson, F.L., 1983, Volcanoes in the sea, the geology of Hawaii (2d. ed.): Honolulu, Hawaii, University of Hawaii Press, 517 p.

Malahoff, Alexander, and Woollard, G.P., 1966, Magnetic surveys over the Hawaiian Islands and their geologic implications: Pacific Science, v. 20, no. 3, p. 265-311.

McKnight, J.H., and Juvik, J.O., 1975, Methodological approaches in Hawaiian fog research: Honolulu, Hawaii, University of Hawaii Water Resources Research Center Technical Report no. 85, 34 p.

Mendonca, B.G., and Iwaoka, W.T., 1969, The trade wind inversion at the slopes of Mauna Loa, Hawaii: Journal of Applied Meteorology, v. 8, no. 2, p. 213-219.

Meyer, William, and Souza, W.R., 1995, Factors that control the amount of water that can be diverted to wells in a high-level aquifer, in Hermann, Raymond, Back, William, Sidle, R.C., and Johnson, A.I., eds., Water Resources and Environmental Hazards: Emphasis on Hydrologic and Cultural Insight in the Pacific Rim, Proceedings of the American Water Resources Association Annual Summer Symposium, Honolulu, Hawaii, June 25-28, 1995, p. 207-216.

Miller, M.E., 1987, Hydrogeologic characteristics of central Oahu subsoil and saprolite: Implications for solute transport: Honolulu, Hawaii, University of Hawaii, M.S. thesis, $231 \mathrm{p}$.

Mink, J.F., and Lau, L.S., 1980, Hawaiian groundwater geology and hydrology, and early mathematical models: Honolulu, Hawaii, University of Hawaii Water Resources Research Center Technical Memorandum Report no. 62, 74 p.

Mink, J.F., and Lau, L.S., 1993, Aquifer identification and classification for the island of Hawai' $i$ : Groundwater protection strategy for Hawai $i$ : Honolulu, Hawaii, University of Hawaii Water Resources Research Center Technical Report no. 191, 108 p.

Mink, J.F., Murabayashi, E.T., and Lau, L.S., 1993, Fiveyear review of state land use districts: Protection of watershed and water resources in Hawai ' $i$ : Honolulu, Hawaii, University of Hawaii Water Resources Research Center Technical Report no. 188, 31 p. 
Moore, J.G., and Clague, David, 1987, Coastal lava flows from Mauna Loa and Hualalai volcanoes, Kona, Hawaii: Bulletin of Volcanology, v. 49, no. 6, p. 752-764.

Moore, J.G., Clague, D.A., Holcomb, R.T., Lipman, P.W., Normark, W.R., and Torresan, M.E., 1989, Prodigious submarine landslides on the Hawaiian ridge: Journal of Geophysical Research, v. 94, no. B12, p. 17,465-17,484.

Moore, R.B., Clague, D.A., Rubin, Meyer, and Bohrson, W.A., 1987, Hualalai volcano: A preliminary summary of geologic, petrologic, and geophysical data, chap. 20 of Decker, R.W., Wright, T.L., and Stauffer, P.H., eds., Volcanism in Hawaii: U.S. Geological Survey Professional Paper 1350, v. 1, p. 571-585.

Moore, J.G., and Fornari, D.J., 1984, Drowned reefs as indicators of the rate of subsidence of the island of Hawaii: Journal of Geology, v. 92, no. 6, p. 752-759.

Moore, J.G., Fornari, D.J., and Clague, D.A., 1985, Basalts from the 1877 submarine eruption of Mauna Loa, Hawaii: New data on the variation of palagonitization rate with temperature: U.S. Geological Survey Bulletin $1663,11 \mathrm{p}$.

Moore, J.G., and Szabo, Barney, 1986, Reef-subsidence chronology for the last half million years, Hawaii [abs.]: The Geological Society of America Abstracts with Programs, v. 18 , no. 2, p. 159.

Nance, Tom, 1991, Saltwater ponds of the O'oma II Project: Recommended circulation system and analysis of environmental effects, appendix F of Helber, Hastert, and Fee, Planners, Final environmental impact statement, O'oma II, north Kona, Hawaii, v.2, November 1991.

Nullet, Dennis, and Giambelluca, T.W., 1990, Winter evaporation on a mountain slope, Hawaii: Journal of Hydrology, v. 112 , no. $3 / 4$, p. 257-265.

Nullet, Dennis, and Sanderson, Marie, 1993, Radiation and energy balances and air temperature, chap. 3 of Sanderson, Marie, ed., Prevailing trade winds: Honolulu, University of Hawaii Press, p. 37-55.

R.M. Towill Corporation, 1978, Feasibility study, surface water impoundment/recharge Pearl Harbor basin Oahu, Hawaii: variously paginated.

Sanderson, Marie, 1993, Introduction, chap. 1 of Sanderson, Marie, ed., Prevailing trade winds: Honolulu, Hawaii, University of Hawaii Press, p. 1-11.

Schroeder, Thomas, 1993, Climate controls, chap. 2 of Sanderson, Marie, ed., Prevailing trade winds: Honolulu, Hawaii, University of Hawaii Press, p. 12-36.

Seckel, G.R., 1962, Atlas of the oceanographic climate of the Hawaiian Islands region: Fishery Bulletin 193, from Fishery Bulletin of the Fish and Wildlife Service, v. 61, p. 373-427, Fish and Wildlife Service, U.S. Department of the Interior.
Souza, W.R., and Voss, C.I., 1987, Analysis of an anisotropic coastal aquifer system using variable-density flow and solute transport simulation: Journal of Hydrology, v. 92, p. 17-41.

State of Hawaii, 1963, Summary of drilling log and pumping test for Keei well 12-8, Keei, south Kona, Hawaii: State of Hawaii, Department of Land and Natural Resources, Circular C23, 14 p.

State of Hawaii, 1968, Summary of drilling log and pumping test for Kalaoa well 12-11, (near Keahole), north Kona, Hawaii: State of Hawaii, Department of Land and Natural Resources, Circular C48, 13 p.

State of Hawaii, 1984, Holualoa exploratory well (State well no. 3657-01), Holualoa, north Kona, Hawaii: State of Hawaii, Department of Land and Natural Resources, Circular C-111, $25 \mathrm{p}$.

State of Hawaii, 1990, Water Resources Protection Plan, volumes I and II, Hawaii Water Plan: State of Hawaii, Commission on Water Resource Management.

State of Hawaii, 1994, The State of Hawaii data book 199394, a statistical abstract: State of Hawaii, Department of Business, Economic Development, and Tourism, June 1994.

State of Hawaii, 1995, North Kona water master plan: State of Hawaii, Department of Land and Natural Resources, Report R-104, variously paginated.

Stearns, H.T., 1985, Geology of the State of Hawaii (2d ed.): Palo Alto, Calif., Pacific Books Publishers, 335 p.

Stearns, H.T., and Macdonald, G.A., 1946, Geology and ground-water resources of the island of Hawaii: Territory of Hawaii, Hawaii Division of Hydrography Bulletin 9,363 p.

Swain, L.A., 1973, Chemical quality of ground water in Hawaii: Honolulu, Hawaii, State of Hawaii, Department of Land and Natural Resources, Report R48, $54 \mathrm{p}$.

Szabo, B.J., and Moore, J.G., 1986, Age of -360-m terrace, Hawaii, and the rate of late Pleistocene subsidence of the island: Geology, v. 14, no. 11, p. 967-968.

Takasaki, K.J., and Mink, J.F., 1982, Water resources of southeastern Oahu, Hawaii: U.S. Geological Survey Water-Resources Investigations Report 82-628, 89 p.

Takasaki, K.J., and Mink, J.F., 1985, Evaluation of major dike-impounded ground-water reservoirs, island of Oahu: U.S. Geological Survey Water-Supply Paper 2217, $77 \mathrm{p}$.

Taliaferro, W.J., 1958, Kona rainfall: Territory of Hawaii, Hawaii Water Authority, 34 p. + app.

U.S. Geological Survey, 1975, Topographic map of the island of Hawaii, Hawaii, 1:250,000 scale.

Water Resource Associates, 1991, Results of drilling and testing Kau (Kohanaiki) well 1 (4458-01), Kau, north 
Kona, Hawaii: Kamuela, Hawaii, Report to Nansay Hawaii Inc., February 1991, 24 p.

Weast, R.C., Lide, D.R., Astle, M.J., and Beyer, W.H., eds., 1989, CRC handbook of chemistry and physics (70th ed.): Boca Raton, Fla., CRC Press, variously paged.

Wentworth, C.K., 1938, Geology and ground water resources of the Palolo-Waialae District: Honolulu, Hawaii, Honolulu Board of Water Supply, 274 p.

Wentworth, C.K., 1939, The specific gravity of sea water and the Ghyben-Herzberg ratio at Honolulu: Honolulu, Hawaii, University of Hawaii Bulletin, v. 18, no. 8, 24 p.

Wentworth, C.K., and Macdonald, G.A., 1953, Structures and forms of basaltic rocks in Hawaii: U.S. Geological Survey Bulletin 994, 98 p.

Williams, J.A., and Soroos, R.L., 1973, Evaluation of methods of pumping test analyses for application to Hawaiian aquifers: Honolulu, Hawaii, University of Hawaii Water Resources Research Center Technical Report no. 70, $159 \mathrm{p}$.

Wolfe, E.W., and Morris, Jean, 1996, Geologic map of the island of Hawaii: U.S. Geological Survey Miscellaneous Investigations Series Map I-2524-A, 1:100,000 scale.

Zucca, J.J., Hill, D.P., and Kovach, R.L., 1982, Crustal structure of Mauna Loa Volcano, Hawaii, from seismic refraction and gravity data: Bulletin of the Seismological Society of America, v. 72, no. 5, p. 1,535-1,550.

\section{APPENDIX A. MODEL RESPONSE TO CHANGES IN HYDRAULIC CHARACTERISTICS}

Two sets of 16 simulations were used to determine model sensitivity to changes in hydraulic conductivity of the dike-complex zone and dike-free volcanic-rocks zone and to a reduction of the number of model zones for the Kona area, island of Hawaii. In these simulations, model zones (fig. 21) were combined to form two horizontal hydraulic-conductivity zones in an attempt to produce a simplified representation of the system. Selected, representative results from the simulations are shown as scatter plots (figs. A1-A3) in which modelcalculated water levels are plotted against measured water levels.

\section{Model Response to Horizontal Hydraulic Conductivity of the Dike-Complex Zone}

A set of 16 simulations was made to determine the effects of the assigned values for coastal leakance and horizontal hydraulic conductivity of the dike-complex zone on model-calculated water levels. In this set, zones were combined in an attempt to produce a simplified representation of the system. The southern marginal dike zone inland of Kailua was grouped with the buried Hualalai dike-complex zone, and the northern marginal dike zone (north of Kalaoa) was grouped with the dikefree volcanic-rocks zone. The horizontal hydraulic conductivity of the dike-free volcanic-rocks zone and the northern marginal dike zone was assigned a value of $7,500 \mathrm{ft} / \mathrm{d}$ for all 16 simulations. All 16 possible combinations of four values of each of two different hydraulic characteristics were used: (1) values of $0.075,0.1,0.25$, and $0.5 \mathrm{ft} / \mathrm{d}$ for the horizontal hydraulic conductivity in the combined zone consisting of the buried Hualalai dike-complex and southern marginal dike zone inland of Kailua, and (2) values of $0.05,0.1,1.0$ and $5.0 \mathrm{ft} / \mathrm{d} / \mathrm{ft}$ for the coastal leakance. Representative results of these simulations are shown as scatter plots (figs. A1-A2) in which model-calculated water levels are plotted against measured water levels. Also shown for reference in each of the scatter plots is the line on which all data points would lie if the model-calculated water levels were exactly equal to the measured values. In the scatter plots, different symbols are used to represent the water levels from wells in different geographic areas.

In each of figures $\mathrm{A} 1$ and $\mathrm{A} 2$, model results are shown for coastal-leakance values of $0.05,0.1,1.0$ and $5.0 \mathrm{ft} / \mathrm{d} / \mathrm{ft}$. Figure A1 shows model results obtained using a horizontal hydraulic-conductivity value of 0.1 $\mathrm{ft} / \mathrm{d}$ for the combined zone consisting of the buried Hualalai dike-complex and southern marginal dike zone inland of Kailua. Figure A2 shows model results obtained using a horizontal hydraulic-conductivity value of $0.5 \mathrm{ft} / \mathrm{d}$ for the same combined zone.

Comparison of results shown in figures $\mathrm{A} 1$ and $\mathrm{A} 2$ indicates that model-calculated water levels in the dikefree volcanic-rocks zone are not affected significantly by the assigned value for the horizontal hydraulic conductivity of the combined zone consisting of the buried Hualalai dike-complex and southern marginal dike zone. Comparison of results shown in figures $\mathrm{A} 1$ and A2, however, indicates that model-calculated water levels in the high water-level area are sensitive to the assigned value for the horizontal hydraulic conductivity of the combined dike-complex zone. A value of $0.1 \mathrm{ft} / \mathrm{d}$ for the horizontal hydraulic conductivity of the dikecomplex zone produced the smallest errors (average difference, average absolute difference, and root-mean- 

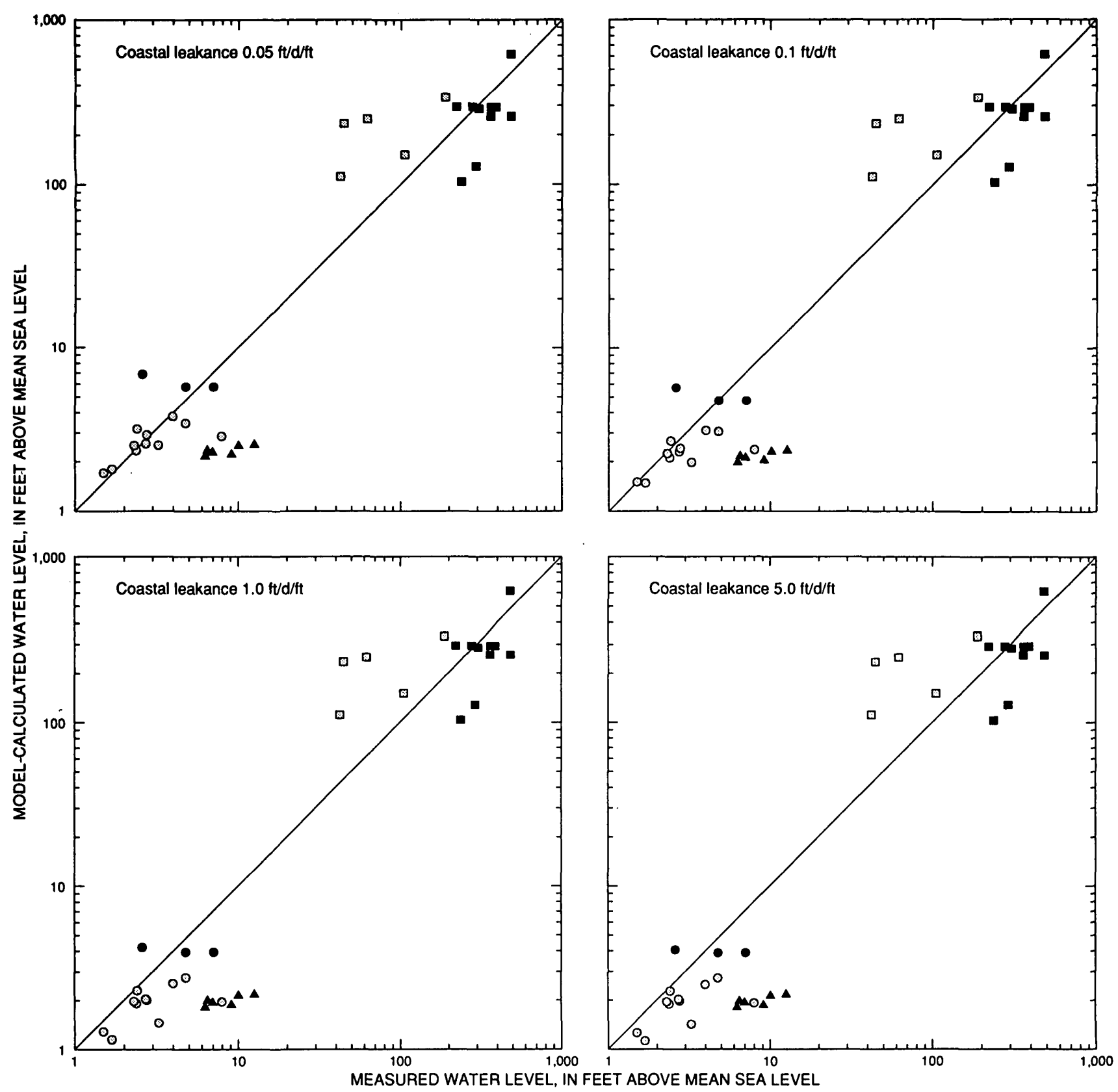

\section{EXPLANATION}
- LINE OF EQUAL MEASURED AND MODEL- CALCULATED WATER LEVEL
- coAstal wells nORTH of KEALAKEKUA bay
- coastal wells south of kealakekua bay

- INLAND WELlS NORTH OF KALAOA

- WELLS IN HIGH WATER-LEVEL AREA BETWEEN PALANI JUNCTION AND HOLUALOA

- WELLS IN HIGH WATER-LEVEL AREA, NORTH OF PALANI JUNCTION OR SOUTH OF HOLUALOA

Figure A1. Measured and model-calculated water levels for 1991-93 pumping conditions, Kona, island of Hawaii, for various values of coastal leakance, a horizontal hydraulic conductivity of 7,500 feet per day for the combined dike-free, volcanic-rocks zone, and a horizontal hydraulic conductivity of 0.1 feet per day for the combined dike-complex zone. 

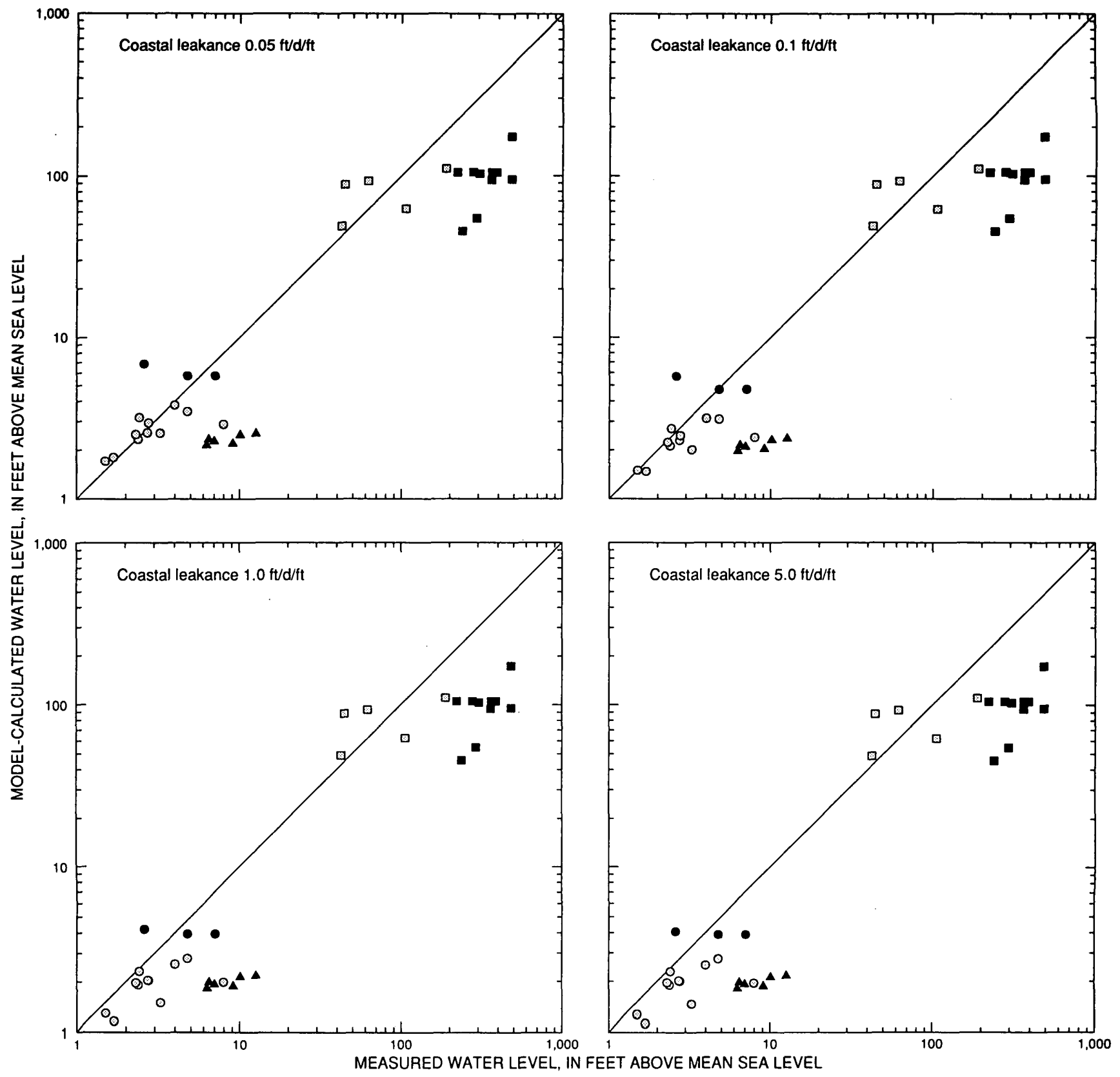

\section{EXPLANATION}

LINE OF EQUAL MEASURED AND MODELCALCULATED WATER LEVEL

- COASTAL WELLS NORTH OF KEALAKEKUA BAY

- coastal wells south of kealakekua bay
- INLAND WELLS NORTH OF KALAOA

- WELLS IN HIGH WATER-LEVEL AREA BETWEEN PALANI JUNCTION AND HOLUALOA

- WELLS IN HIGH WATER-LEVEL AREA, NORTH OF PALANI JUNCTION OR SOUTH OF HOLUALOA

Figure A2. Measured and model-calculated water levels for 1991-93 pumping conditions, Kona, island of Hawaii, for various values of coastal leakance, a horizontal hydraulic conductivity of 7,500 feet per day for the combined dike-free, volcanic-rocks zone, and a horizontal hydraulic conductivity of 0.5 feet per day for the combined dike-complex zone. 


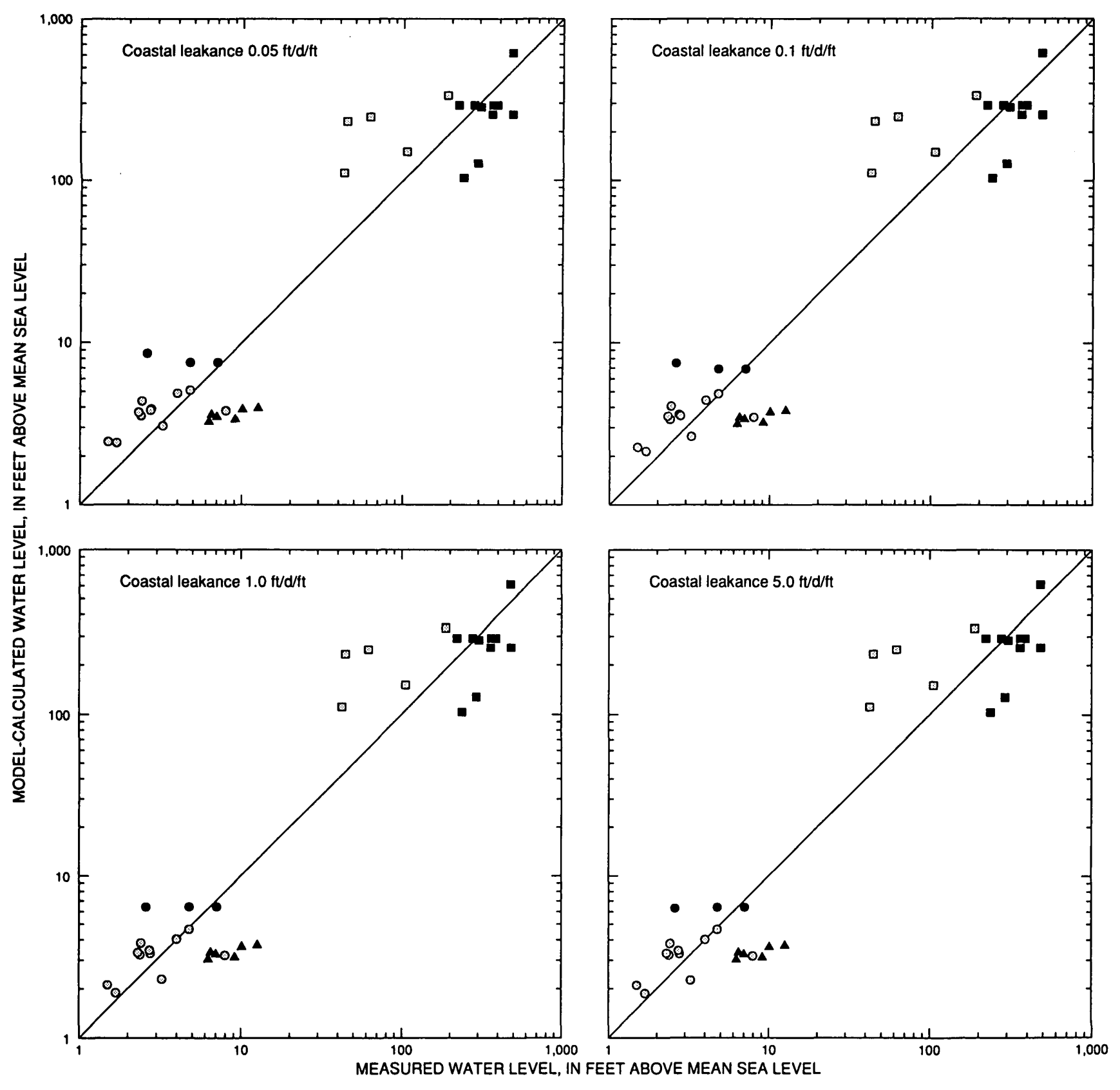

\section{EXPLANATION}

LINE OF EQUAL MEASURED AND MODELCALCULATED WATER LEVEL

- COASTAL WELLS NORTH OF KEALAKEKUA BAY

- coastal wells south of KEALAKEKUA bay
\ INLAND WELLS NORTH OF KALAOA

- WELLS IN HIGH WATER-LEVEL AREA BETWEEN PALANI JUNCTION AND HOLUALOA

- WELLS IN HIGH WATER-LEVEL AREA, NORTH OF PALANI JUNCTION OR SOUTH OF HOLUALOA

Figure A3. Measured and model-calculated water levels for 1991-93 pumping conditions, Kona, island of Hawaii, for various values of coastal leakance, a horizontal hydraulic conductivity of 2,500 feet per day for the combined dike-free, volcanic-rocks zone, and a horizontal hydraulic conductivity of 0.1 feet per day for the combined dike-complex zone. 
square of the difference) between model-calculated and measured water levels for all wells in the high waterlevel area. A value of $0.5 \mathrm{ft} / \mathrm{d}$ for the horizontal hydraulic conductivity of the dike-complex zone produced the smallest errors between model-calculated and measured water levels for wells in the high water-level area between Palani Junction and Holualoa. Model-calculated water levels in the high water-level area (figs. A1, A2) are not sensitive to the assigned value for the coastal leakance.

\section{Model Response to Horizontal Hydraulic Conductivity of the Dike-Free Zone}

A second set of 16 simulations was made to determine the effects of the assigned values for coastal leakance and horizontal hydraulic conductivity of the dikefree volcanic rocks on model-calculated water levels. Zones were combined in an attempt to produce a simplified representation of the system. The horizontal hydraulic conductivity of the dike-complex zone and the southern marginal dike zone inland of Kailua was assigned a value of $0.1 \mathrm{ft} / \mathrm{d}$ for all 16 simulations. All 16 possible combinations of four values of each of two different hydraulic characteristics were used: (1) values of 2,$500 ; 5,000 ; 7,500$; and $10,000 \mathrm{ft} / \mathrm{d}$ for the horizontal hydraulic conductivity in the combined zone consisting of the dike-free volcanic rocks and northern marginal dike zone, and (2) values of $0.05,0.5,1.0$ and $5.0 \mathrm{ft} / \mathrm{d} / \mathrm{ft}$ for the coastal leakance. Representative results of these simulations are shown as scatter plots (figs. A1 and A3).

In each of figures $\mathrm{A} 1$ and $\mathrm{A} 3$, model results are shown for coastal-leakance values of $0.05,0.1,1.0$ and $5.0 \mathrm{ft} / \mathrm{d} / \mathrm{ft}$. Figure A1 shows model results obtained using a horizontal hydraulic-conductivity value of $7,500 \mathrm{ft} / \mathrm{d}$ for the combined zone consisting of the dikefree volcanic rocks and northern marginal dike zone. Figure A3 shows model results obtained using a horizontal hydraulic-conductivity value of $2,500 \mathrm{ft} / \mathrm{d}$ for the same combined zone.

Comparison of results shown in figures $\mathrm{A} 1$ and $\mathrm{A} 3$ inglicates that model-calculated water levels in the high water-level area are not affected significantly by the assigned value for the horizontal hydraulic conductivity of the combined zone consisting of the dike-free volcanic rocks and northern marginal dike zone. In addition, model-calculated water levels in the high water-level area are not sensitive to the assigned value for the coastal leakance. Comparison of results shown in figures $\mathrm{A} 1$ and $\mathrm{A} 3$, however, indicates that model-calculated water levels in the dike-free volcanic-rocks zone are sensitive to the assigned values for the coastal leakance and the horizontal hydraulic conductivity of the combined zone consisting of the dike-free volcanic rocks and northern marginal dike zone. Values of 0.05 $\mathrm{ft} / \mathrm{d} / \mathrm{ft}$ for the coastal leakance and $7,500 \mathrm{ft} / \mathrm{d}$ for the horizontal hydraulic conductivity of the combined zone (consisting of the dike-free volcanic rocks and northern marginal dike zone) produced the smallest errors (average difference, average absolute difference, and rootmean-square of the difference) between model-calculated and measured water levels in the dike-free volcanic-rocks zone north of Kealakekua Bay where data are most reliable. In all 16 cases, however, model-calculated water levels at inland wells north of Kalaoa were lower than measured water levels (figs. A1, A3).

\section{Discussion of Simplified Model}

Results from the two sets of simulations indicate that a simplified model, in which the northern marginal dike zone is grouped with the dike-free volcanic rocks, and the southern marginal dike zone is grouped with the dike-complex zone, is not capable of producing modelcalculated water levels in agreement with measured water levels in all areas. Results from these simulations indicate that the horizontal hydraulic-conductivity values of the marginal dike zones lie between the values for the dike-free volcanic rocks and dike-complex zones. Information from these simulations was used to estimate the final hydraulic-conductivity and coastalleakance values (table 5). 


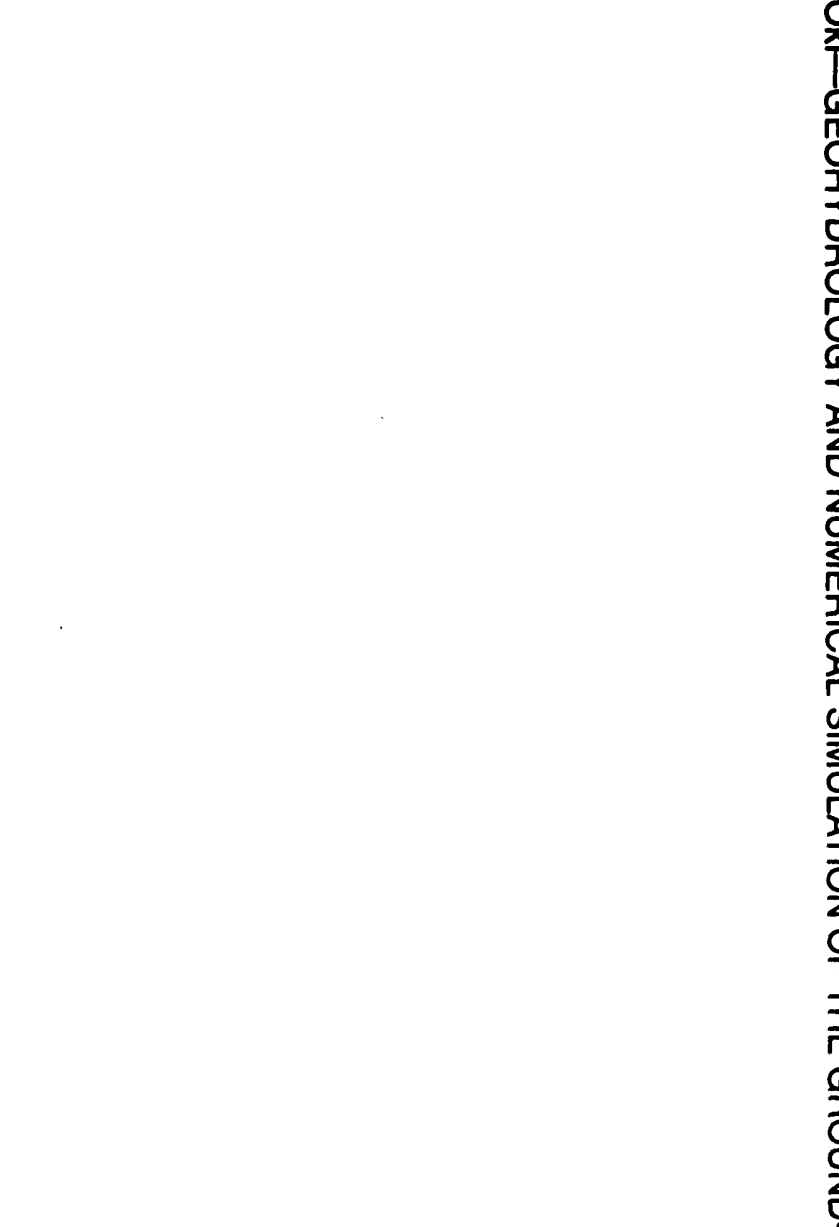

89 Printed on recycled paper

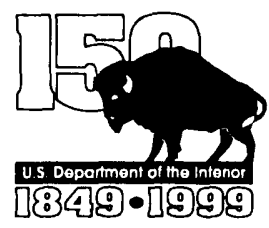

